\title{
Designing a Valid and Reliable Instrument to Measure Teachers' Use and Perceptions of Initiatives that Address the Low Socioeconomic Achievement Gap in West Virginia Title I Schools
}

\author{
Rosemary Beatrice Coyle Anderson
}

Follow this and additional works at: https://researchrepository.wvu.edu/etd

\section{Recommended Citation}

Coyle Anderson, Rosemary Beatrice, "Designing a Valid and Reliable Instrument to Measure Teachers' Use and Perceptions of Initiatives that Address the Low Socioeconomic Achievement Gap in West Virginia Title I Schools" (2016). Graduate Theses, Dissertations, and Problem Reports. 7073.

https://researchrepository.wvu.edu/etd/7073

This Dissertation is protected by copyright and/or related rights. It has been brought to you by the The Research Repository @ WVU with permission from the rights-holder(s). You are free to use this Dissertation in any way that is permitted by the copyright and related rights legislation that applies to your use. For other uses you must obtain permission from the rights-holder(s) directly, unless additional rights are indicated by a Creative Commons license in the record and/ or on the work itself. This Dissertation has been accepted for inclusion in WVU Graduate Theses, Dissertations, and Problem Reports collection by an authorized administrator of The Research Repository @ WVU.

For more information, please contact researchrepository@mail.wvu.edu. 
Designing a Valid and Reliable Instrument to Measure Teachers' Use and Perceptions of Initiatives that Address the Low Socioeconomic Achievement Gap in West Virginia Title I Schools

Rosemary Beatrice Coyle Anderson

Dissertation Submitted to the College of Education and Human Services

At West Virginia University

In partial fulfillment of the requirements for the degree of

Doctor of Education

in

Educational Leadership Studies

Helen M. Hazi, Ph. D., Chair

M Cecil Smith, Ph. D.

Bonnie A. Ritz, Ed. D.

Neal Shambaugh, Ph. D.

Samuel F. Stack, Ph. D.

Keith W. Trahan, Ph. D.

Morgantown, WV

Keywords: Achievement Gap, Poverty, Low SES Subset, Title I, Reform Initiatives Copyright 2016 Rosemary Anderson 


\begin{abstract}
Designing a Valid and Reliable Instrument to Measure Teachers' Use and

Perceptions of Initiatives that Address the Low Socioeconomic Achievement Gap in West

Virginia Title I Schools
\end{abstract}

\title{
Rosemary Anderson
}

Initiatives that research tells us should be increasing achievement for poor children have not succeeded in reducing the achievement gap for the low socioeconomic subset in the United States and in West Virginia schools (Reardon, 2011; WVDE, 2009). This study developed a valid and reliable instrument to examine teachers' perceptions of the use of 16 research based initiatives that have been directed to improving the achievement gap of poor children. The research question was: What are the psychometric properties of a survey instrument that is designed to assess teachers' perceptions of the uses and effectiveness of reform initiatives that have been implemented in high poverty schools to address the academic achievement of lowSES students in Title I schools? The survey asks teachers about nine policy implementation factors for each of these reform initiatives as well as whether the initiative has improved the academic achievement of their students. Finally, the survey examines the significance of seven teacher demographics on perceptions. There were two phases: 1) the development of the instrument, and 2) establishing the validity and reliability of the instrument. Phase 1 consisted of the survey items for the instrument and the four components in the design of the study-identifying and describing the problem; the review of literature; identifying the specific target population and method for collecting data; and instrument development. In Phase 2 validity was established through a panel of experts. Reliability for each initiative and all factors was established through a split-half reliability test using Cronbach's Alpha. Reliability was established for all initiatives and factors with the minimum reliability coefficient at .749 and a maximum of .994 . This instrument can be used with confidence that it is valid and reliable. The survey can be used in West Virginia or adapted for use at other locations to measure teachers' use and perceptions of those reform initiatives that may help improve the academic achievement of poor children and narrow the achievement gap for the low socioeconomic subset. 


\section{Acknowledgements}

I grew up in a family of nine children. My mother came from England after the war, a fact that we all thought was so amazing. She was the smartest person I have ever known. My father was the strongest and the kindest. Our parents believed in us and then we believed in ourselves. This belief in being special was grounded in our parents' understanding of the importance of support for those in your care and in your life. This year I lost a sister who will never see another rainbow, paint another picture, or watch a bluebird fly. It gave me pause to consider the many people who have helped me do special things and the importance of letting them know how important they have been to me through this process. This latest effort would not have been possible without the encouragement and help of many people.

First I thank my family-Sam, Michael, Tim, Cady, Belle, Wesley, Sheena, Lyn, Vicky, Betsy, Cynthia, Tom, Julie, and Jim. My husband was patient and helpful. Dr. Bonnie Ritz was so supportive and such a good friend. Dr. Keith Trahan spent many hours giving good advice on survey design and evaluation. Dr. Marilyn Roseman, my very smart sister, was a source of inspiration. Dr. Hazi spent countless days and nights heroically trying to decipher what I was doing. She came to the rescue when I needed rescued. This journey would not have been possible without her. Thanks to the other professors on my committee-Dr. Smith, Dr. Shambaugh, and Dr. Stack, who agreed at the last moment to help me through the process. Rosemary Hriblan, Char Allen, and Connie Miranov were always so nice. Dr. Williams was amazing and introduced me to John Rawls and ethics. I must also thank Larry White for his always positive help, knowledge, and expertise. A journey made possible by many good people.

In memory of Valerie Joan Coyle Ferner. 


\section{Table of Contents}

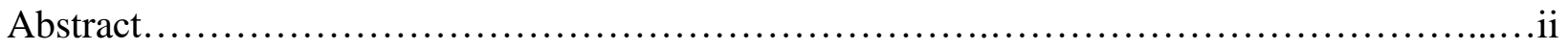

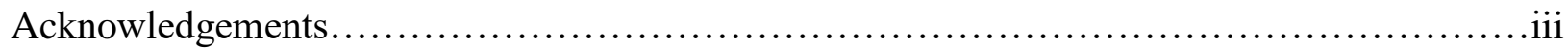

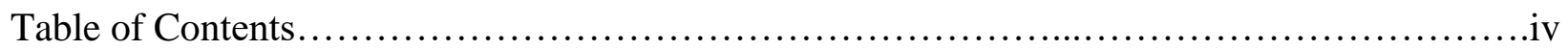

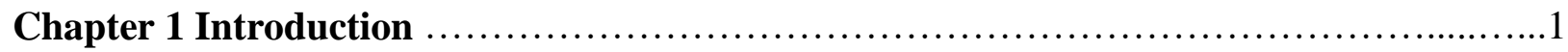

Purpose of Study and Research Question.........................................

Justification for Study.....................................................

Research Design...........................................................

Definition of Terms..........................................................

Organization of Document................................................

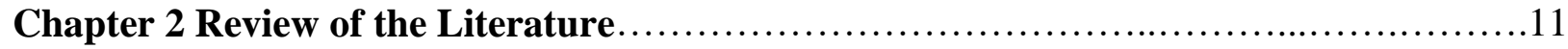

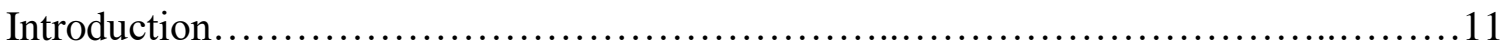

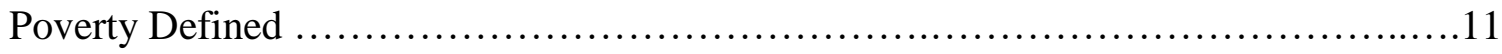

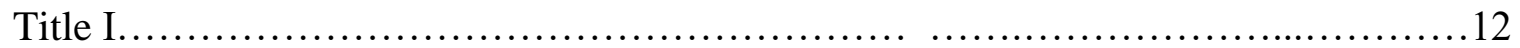

Poverty and Achievement................................................. 13

Primary Risk Factors for the Low Socioeconomic Child............................15

Emotional and Social Challenges........................................ 16

Chronic and Acute Stressors...........................................18

Cognitive Lags ...................................................... 19

Health and Safety Issues............................................ 19

The Failure of Education Reforms..............................................20

Equity-Based Reforms...........................................20

Civil Rights................................................21

Head Start....................................................22

Federal Nutrition Programs.......................................22

Title I....................................................22

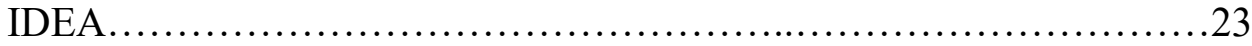

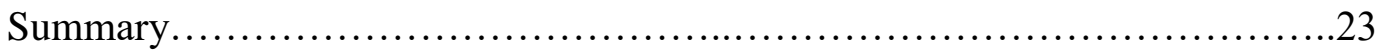




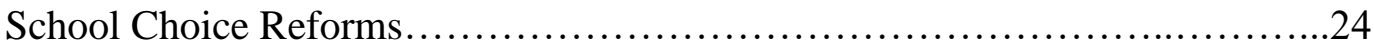

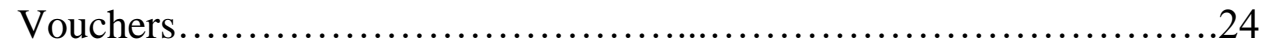

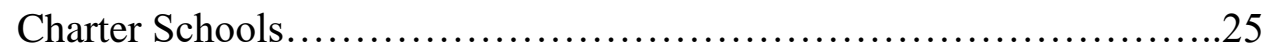

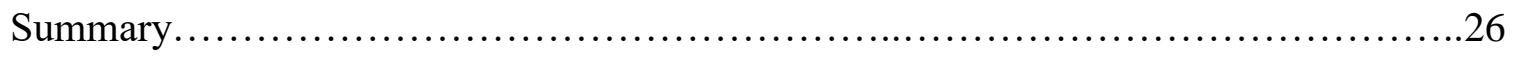

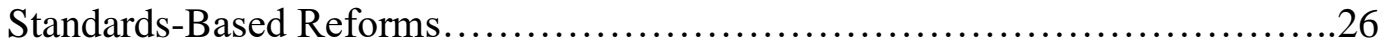

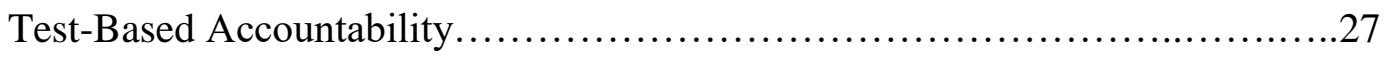

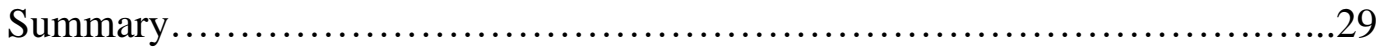

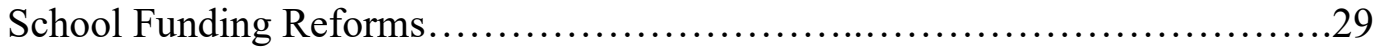

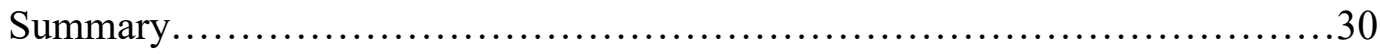

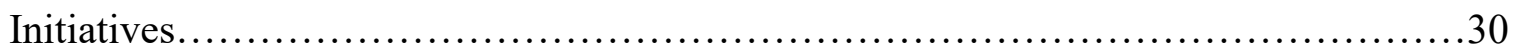

Extended learning Time.....................................................

Preschool.................................................................... 31

After School Programs.................................................................32

Adding Minutes, Hours, and/or Days.................................33

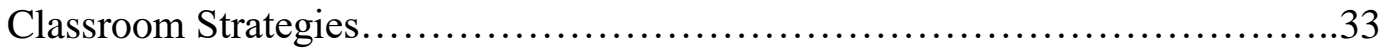

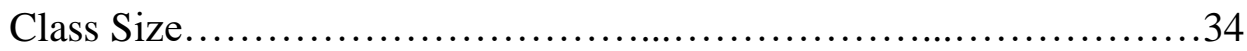

Teachers' High Expectations........................................... 34

Teaching Resilience and Coping Skills.................................... 35

Increased Time in Physical Activity..................................37

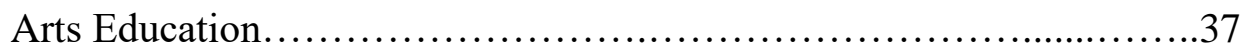

Summative High-Stakes Standardized Testing..........................37

Formative Assessment............................................... 38

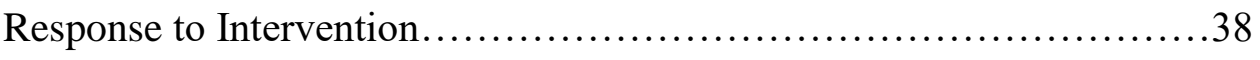

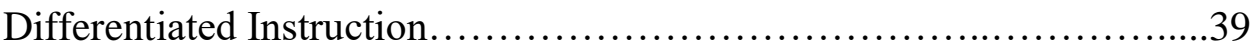

Supplemental Services............................................40

Early Screening. ............................................ 40

School-Based Health Centers and Wraparound Services...........41 
Food and Nutrition Programs............................41

Other Influences..........................................42

West Virginia Initiatives Proposed to Address the Low SES Achievement Gap.........42

Extended Time....................................................43

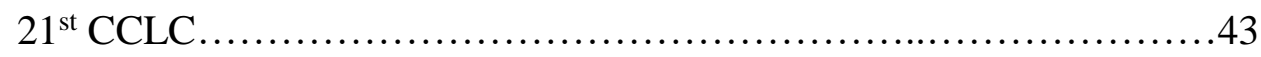

Early Childhood Education......................................43

Public Preschool Education ....................................44

Classroom Strategies.................................................44

Class Size...................................................44

RTI.......................................................44

Differentiated Instruction.....................................45

Fitness.................................................... 45

Testing...................................................45

High Schools That Work....................................45

Supplemental Services........................................... 45

Other influences.......................................................46

Teacher Training..............................................46

National Board Certification...................................47

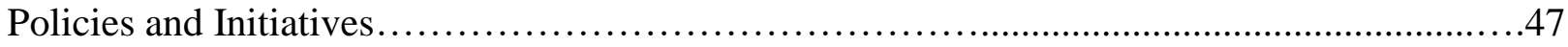

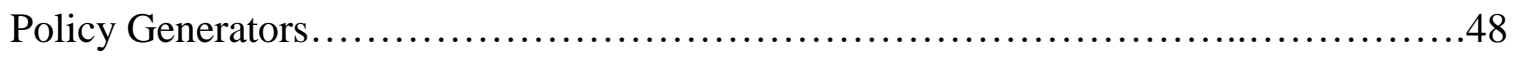

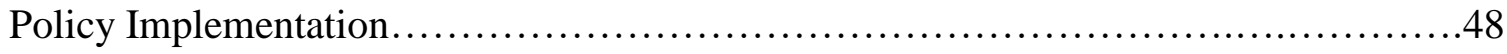

Policy Implementation in West Virginia..........................................48

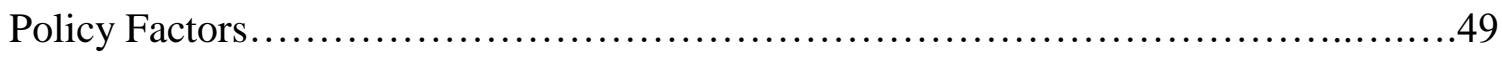

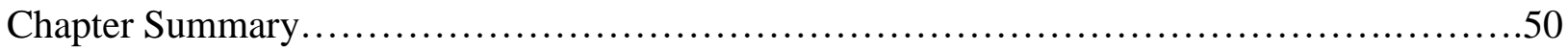




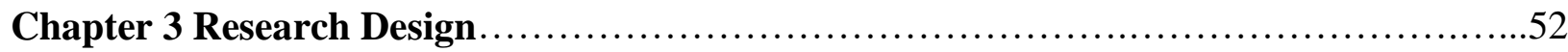

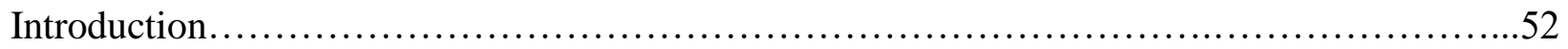

Research Question.......................................................... 52

Research Methodology.......................................................... 53

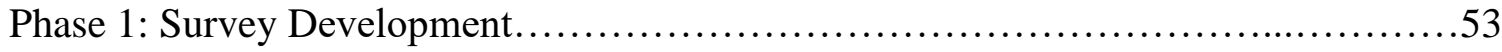

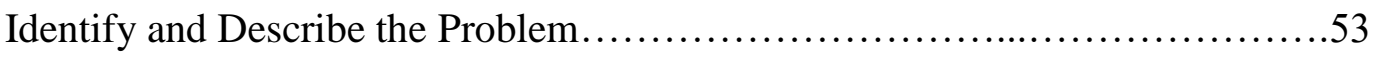

Review of the Literature ...............................................55

Identify the specific target population, the instrument, and the measureable and observable data that will be collected......................................56

Instrument Development............................................57

Clear Directions ................................................58

Wording ...................................................... 59

Close-ended Items ..........................................60

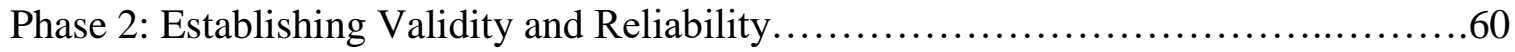

Survey Validity................................................60

Survey Reliability................................................61

Cognitive Interviews.........................................................

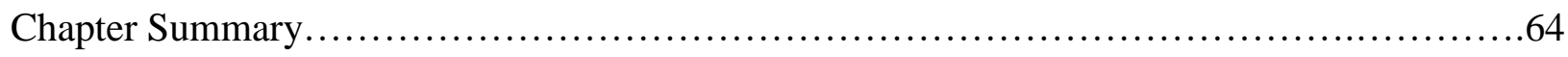

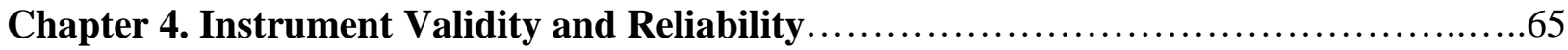

Validity Results..........................................................65

Reliability Results.....................................................66

Survey Results......................................................67 


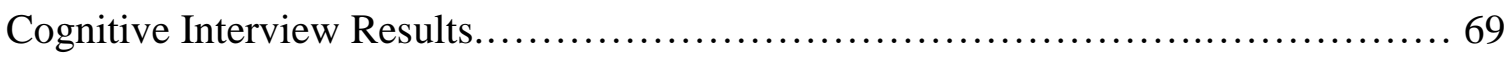

Think Aloud........................................................... 70

Retrospective Interviewing ............................................ 71

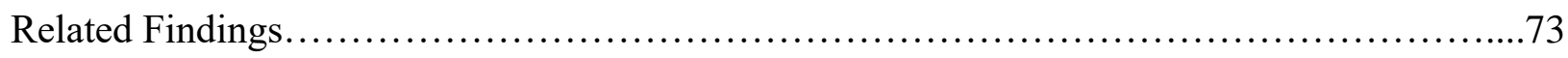

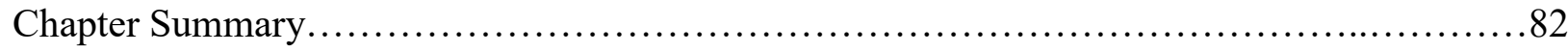

Chapter 5. Findings and Recommendations ........................................... 83

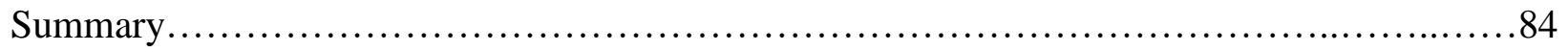

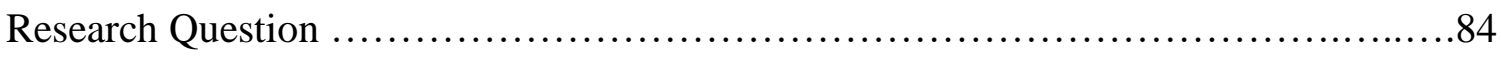

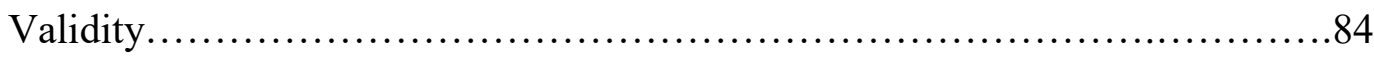

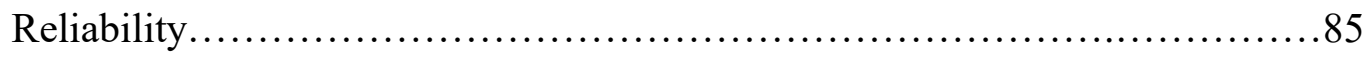

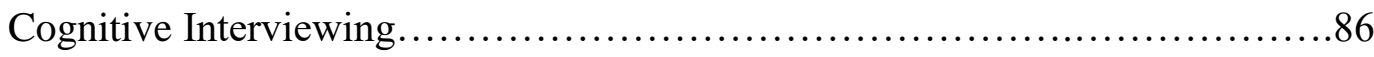

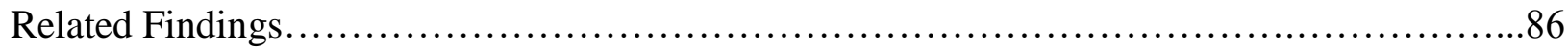

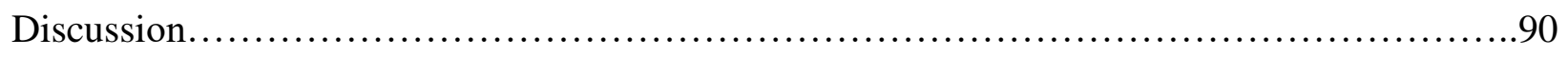

Recommendations for Survey Administration.....................................93

Recommended Data Analysis for the Survey....................................94

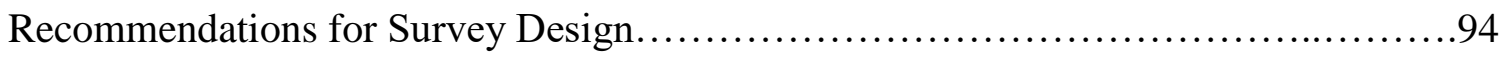

Recommendations for Future Research.......................................97

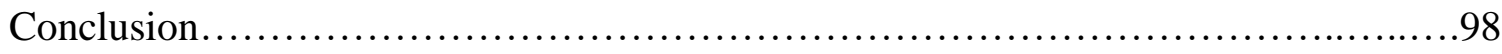

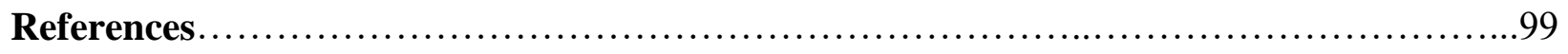

Appendices

A. Policy Implementation Factors........................................................ 122

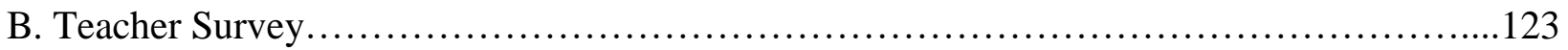


C. Chart Linking Initiative and Research........................................ 158

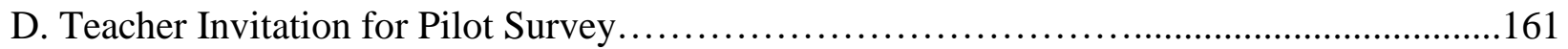

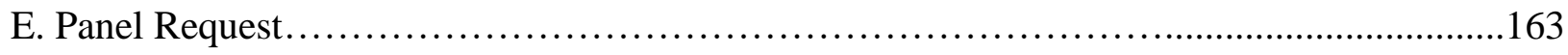

F. Panel Item Review.................................................................. 165

G. Panel Review Results............................................................... 176

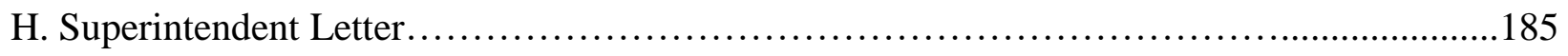

I. Principal Letter................................................................... 186

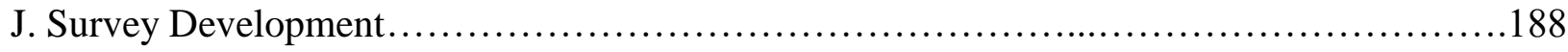

K. Teachers' Perceptions of Reform Initiatives Survey................................ 189

Tables

1. Reliability Coefficients of Initiatives ..........................................68

2. Results of Cognitive Interview Questions...............................................

3. Improved Academic Achievement Means......................................... 75

4. Means of Factors for Each Initiative and Five Implementation Factors.....................77

5. Means of Factors for Each Initiative and Four Implementation Factors.....................79 


\section{Chapter 1}

\section{Introduction}

On December 5, 2014, the West Virginia Department of Education (WVDE) reported that the low socioeconomic subset of West Virginia public school students was ten percentage points below all West Virginia students in math proficiency and nine percentage points behind in reading proficiency (West Virginia Department of Education, 2014d). The achievement gap associated with the low socioeconomic group persists in West Virginia and across the United States (Reardon, 2011). Typically, teachers have little input into evaluating or implementing initiatives in their classrooms. Creating an instrument that will allow teachers in the classrooms to have input by accessing their perceptions of reform initiatives that have been proposed through national and state studies to improve academic achievement for the poor children in West Virginia may provide important information to policy makers and education leaders.

The passage of the No Child Left Behind Act (NCLB) of 2001 brought the federal government into classrooms, creating a focus on achievement and the achievement gaps between certain groups of students. NCLB revised Title I, which is a supplemental entitlement to high

poverty schools by mandating that Title I schools, districts, and states conduct yearly testing and assessments of students; report on schools' adequate yearly progress (AYP); identify schools for improvement and corrective actions; provide supplemental services and /or school choice under certain circumstances, and report the schools' performances and teacher qualifications, among other requirements (WVDE, 2014c). The Every Student Succeeds Act (ESSA) was signed by President Obama on December 10, 2015, reauthorizing the No Child Left Behind Act. ESSA 
reaffirms the focus on closing the achievement gap and making sure all subsets including low SES children achieve (USDE, 2004a).

This focus on achievement linked to federal aid and sanctions caused a flurry of initiatives aimed at improving the performances of all students and especially those subsets that were traditionally low performing, including the low socioeconomic subset. But these initiatives have not usually included input from a significant constituency. Classroom teachers who ultimately affect the potency of reforms have seldom been consulted on their perceptions of the poor children within their classrooms and the accumulated effects of poverty on their classrooms and schools. Teachers have not been asked about the use of reform initiatives and whether they have improved student achievement.

The actual title of the No Child Left Behind Act reflects the concern for students in underachieving populations--An Act to Close the Achievement Gap with Accountability, Flexibility, and Choice, so that No Child is Left Behind (USDE, 2008, sec.1). Much debate has resulted from the many provisions of the bill, including contentions that there was a lack of adequate funding and an overreliance on test scores. The No Child Left Behind Act has been criticized for penalizing schools and districts for poor results which reflect the very conditions that create high concentrations of poverty. Nevertheless, attention since the enactment of this legislation has been riveted on achievement gaps of underperforming children. Accompanying this mandate and reflected in the title of the bill was the additional requirement that these statistics show the proficiency levels of specific subsets including African American, White, Low SES, Asian, Students with Disabilities, Hispanics, Asian/Pacific Islanders, Native Americans, and English Language Learners. This requirement ultimately confirmed the 
significance of the gaps in performance between the subsets. Since then, states, counties, and schools have worked to reduce these gaps.

In her book, Inside Teaching, Mary Kennedy (2005) recognized the impact of teachers on school reform initiatives such as those being proposed to impact achievement gaps. Kennedy interviewed teachers in schools that had experienced reforms to find out why reforms were not more successful. Her research found that reformers seldom take into account the realities of the classroom. Teachers often held different values and beliefs and did not have the necessary equipment and materials to implement complicated reforms (Kennedy, 2005). Teachers are critical to the effective implementation of school reforms, as well as responsible for the classroom cultures that enable or prohibit reforms and general student success. This study developed an instrument that can survey all classroom teachers and Title I specialists in Title I schools in West Virginia. Teachers would be given a set of reform initiatives as suggested within the literature and from the Closing the Achievement Gap Report for 21st Century Learners in West Virginia (WVDE, 2009). They would be asked if they use these initiatives and if the initiatives have improved the academic achievement of their students. For each reform initiative, teachers would be asked about their perceptions of a set of nine policy implementation factors that have been proven to affect policy implementation.

\section{Purpose of the Study and Research Question}

The purpose of the study was to develop a valid and reliable tool that will measure teachers' use and perceptions of national and West Virginia initiatives directed at the achievement gap for the low socioeconomic subset in West Virginia Title I schools. 
The research question was: What are the psychometric properties of a survey instrument that is designed to assess teachers' perceptions of the uses and effectiveness of reform initiatives that have been implemented in high poverty schools to address the academic achievement of low-SES students in Title I schools?

\section{Justification for the Study}

In a 2015 survey of a nationally representative sample of 3,328 public school teachers by the Center on Education Policy, teachers overwhelmingly reported that their voices were not a part of the policy making process on district, state, and national levels, although more than onehalf reported having some input at the school level (Will, 2016).

The Teaching Ambassador Fellowship was formed by the U. S. Department of Education (2016) to provide teacher input into education reforms and policies. This program seeks to improve education for students by involving teachers in the development and implementation of national education policy. A lack of teacher input into initiatives that are used in their classrooms has been documented in a study of 450 education reforms across 34 countries conducted by the Organization for Economic Co-operation and Development (OECD). In a study of 450 education reforms across 34 countries, only one in ten education reforms had been analyzed for their impact on proposed outcomes. The report emphasized that teacher and parent input were critical elements in the success of reforms (Ware, 2015).

Conferences, books, speakers, and research have examined the achievement gaps and have offered reasons for their existence and suggestions of what can be done to reduce and/or eliminate them. States, including West Virginia, have instituted policies affecting standards, practice, curriculum, and training. Teachers, however, have had little input into initiatives. 
The study was based on a review of the literature on achievement, policies, and initiatives, and through a review of the 2009-2010 report Closing the Achievement Gap Report for 21 st Century Learners in West Virginia (WVDE, 2009). There are several reasons for the choice of the low SES subset. The major subgroups with appreciable numbers in West Virginia achievement gaps are African Americans, Students with Disabilities, and the Economically Disadvantaged (SES). West Virginia does not have appreciable numbers of remaining minority and ELL students throughout the state. The West Virginia Department of Education's Closing the Achievement Gap Report for $21^{\text {st }}$ Century Learners in West Virginia (2009) looked only at three subsets: African American, Low Socioeconomic, and Children with Disabilities. As a statistically poor state with $18 \%$ of the total population living in poverty, the low SES subset affects most of the schools in the state (Kids Count, 2015).

'The 2015 KIDS COUNT Data Book shows that West Virginia ranks 43rd in the country for child well-being, a significant drop from last year's ranking of 37th,' said Margie Hale, executive director of West Virginia KIDS COUNT. 'More importantly, our child poverty rate has continued to climb since the Great Recession and has now jumped to 27 percent of all West Virginia kids. Since 2008, the number of children living in poverty has risen by almost 15 percent from 87,000 to 100,000 . That's the highest child poverty rate we've seen in more than a decade.' (Kids Count Data Book, 2015, para. 3)

Teachers are critical to the effective implementation of school reforms as well as responsible for the classroom cultures that enable or prohibit reforms and general student success. In her book, Inside Teaching, Mary Kennedy (2005) recognized the impact of teachers on school reform interventions, such as those being proposed to impact achievement gaps. In her study Mary Kennedy conducted 45 interviews in locations where reform policies were being 
instituted, specifically in California, Vermont, North Carolina, Michigan, and one charter school. Kennedy examined some of the common beliefs for failure of reforms. Teachers did not have sufficient knowledge, or held beliefs and dispositions that were inconsistent with reforms. Another belief was that circumstances did not allow teachers to be able to implement reforms successfully. Finally, Kennedy added that reforms may not be realistic and may actually "impede practice" (Kennedy, 2005, p. 12). Although teachers are often blamed for the failure of reforms, Mary Kennedy identified other factors that policy makers and reformists did not consider. Teachers had little time to prepare and were responsible for multiple activities at the same time (Kennedy, 2005). Teachers experienced distractions and interruptions. Reform lessons were often complicated and needed props that often were unavailable or hard to find. Reformers seldom consider these classroom realities. She concluded that reform policies were often unrealistic and conflicted with each other. Often the reform preparations and activities left exhausted teachers trying to implement unrealistic reforms.

In Reign of Error, Diane Ravitch (2013) also examined the failure of reformist policies. Too often teachers are incorrectly blamed when reform initiatives are not successful. Teachers are the very professionals who should shape the reforms that they use. Their knowledge of classroom realities is important. They should be free to enter the conversation and to question policies that they believe are harmful to their students (Ravitch, 2013). Cohen and Spillane (1992) also concluded that knowledge of what actually happens in classrooms is limited, and often reforms are not instituted as intended.

The study is a first effort to access the voices of classroom teachers and Title I specialists in Title I schools in West Virginia to give policy makers and education leaders information about which of the reform initiatives are being used. 


\section{Research Design}

A quantitative design was used to conduct this research. The purpose of the study was to develop a valid and reliable tool that will measure teachers' use and perceptions of national and West Virginia initiatives directed at the achievement gap for the low socioeconomic subset in West Virginia Title I schools. There were two phases: 1) the development of the instrument, and 2) establishing the validity and reliability of the instrument. Phase 1 consisted of the survey items for the instrument and the four components in the design of the study-- identifying and describing the problem; the review of literature; identifying the specific target population and method for collecting data; and instrument development. In Phase 2 validity was established through a panel of experts. Reliability for each initiative and all factors was established through a split-half reliability test using Cronbach's Alpha. This survey can provide information on teachers' perceptions about the use of reform initiatives, if initiatives are improving academic achievement in West Virginia Title I schools, and if these initiatives have been facilitated by including factors that have been proven to help implementation. Survey findings can then be given to policy makers, educators, legislators, and other stakeholders.

\section{Definition of Terms}

Achievement Gap: Achievement gaps occur when one group of students outperforms another group and the difference in average scores for the two groups is statistically significant (that is, larger than the margin of error) (National Center for Education Statistics, 2014, Intro.).

Free/reduced: Free lunch status is determined to be below $130 \%$ of the poverty level and Reduced refers to those between 130 and $185 \%$ of poverty. In 2015 the poverty threshold for a family of 4 was $\$ 24,259$ (United States Census Bureau, 2016). 
Initiative: A plan or program that is intended to solve a problem. An act or strategy intended to resolve a difficulty or improve a situation; a fresh approach to something: This definition will be used for the purposes of this study to include those acts, strategies, programs, practices, and reforms being included in the study.

Low SES Students: In West Virginia the low SES subset is comprised of all students who receive free or reduced lunches.

NCLB: The No Child Left Behind Act of 2001 was an act of Congress reauthorizing the Elementary and Secondary Education Act "to close the achievement gap with accountability, flexibility, and choice, so that no child is left behind" (U.S. Department of Education, 2004a, n.p.).

Policy: A definite course or method of action selected from among alternatives and in light of given conditions to guide and determine present and future decisions. A high-level overall plan embracing the general goals and acceptable procedures especially of a government body.

Programmatic level: In Policy 2510, §126-42-5, the West Virginia Department of Education defines three programmatic levels for the P-12 school setting: early learning programs (Pre-K-5), middle level learning programs (grades 6-8), and adolescent education programs, (grades 9-12).

Title I: "Title I, Part A (Title I) of the Elementary and Secondary Education Act, as amended (ESEA) provides financial assistance to local educational agencies (LEAs) and schools with high numbers or high percentages of children from low-income families to help ensure that all children meet challenging state academic standards" (USDE, 2014, Program Description, para. 1). 
Title I Schoolwide Program: A school must have at least $40 \%$ of its enrolled students who qualify as poor to be eligible for a schoolwide project that then allows the school to offer services to all children (USDE, 2014, Program Description, para 3).

Title I Targeted Assistance Program: Schools that do not have 40\% of its enrolled students who qualify as poor or who choose not to have a schoolwide project are targeted assistance schools and "...must focus Title I services on children who are failing, or most at risk of failing, to meet state academic standards" (USDE, 2014, Program Description, para 3).

\section{Organization of Document}

Chapter 1 presents an overview of the document including the purpose of the study, justification for the study, the research question, and the research design. It includes a definition of terms and outlines the organization of the document.

Chapter 2 will review the literature and define poverty, Title I, and the effects of poverty on achievement. Chapter 2 will then examine the failure of educational reforms and will list reform initiatives from the research that have been recommended to improve the academic achievement of poor students. Policy generation and implementation in West Virginia will explain the roles played by the West Virginia Legislature, West Virginia Board of Education, West Virginia Department of Education and other organizations. Factors that affect successful implementation of reform initiatives will be listed.

Chapter 3 will list the introduction, the purpose of the study, and the research methodology. Under methodology there are two phases: Phase 1- Survey Development and 
Phase 2-Establishing Validity and Reliability. Finally, the chapter will discuss the cognitive interviews and end with the chapter summary.

Chapter 4 contains the results of the validity and reliability procedures and the chapter summary. Chapter 5 will present an introduction, discussion, and future recommendations for survey administration, data analysis for the survey, survey design, and additional research. It will end with dissemination of results and conclusions. 


\section{Chapter 2}

\section{Review of the Literature}

\section{Introduction}

The purpose of the study was to develop a valid and reliable tool that will measure teachers' use and perceptions of initiatives directed at the achievement gap for the low socioeconomic subset in West Virginia Title I schools.

The information found in chapter 2 is used as background and as the bases for constructing the survey. The first sections on Poverty Defined, Title I, Poverty and Achievement, and At-Risk Factors for the Low SES Child provide background for the research. The next sections on the Failure of Education Reforms address why the reforms and closing the achievement gap have been so difficult. The third section contains reform initiatives selected based on three criteria: 1) they address the needs of the low SES child, 2) they are based in research, and 3) they have been implemented in public schools. The section on the WVDE reform initiatives lists those initiatives found in West Virginia to address the achievement gap for the low socioeconomic child. The sections on Policies and Initiatives form the basis for the choice of factors that affect successful implementation of initiatives.

\section{Poverty Defined}

The definition of poverty in the United States became a government responsibility in the mid-1960s when President Lyndon Johnson established the Research Institute on Poverty. Johnson believed that, in order to fight poverty, a definition was needed (Research Institute on Poverty, 2014). The poverty thresholds were designed by the Department of Agriculture in 1963- 
64 using Department of Agriculture emergency food budget data and the portion of family income spent on food. At that time it was considered that a family of three spent approximately one-third of its income on food. The Census Bureau uses a set of money income thresholds that vary by family size and composition to determine who is in poverty. "If a family's total income is less than the family's threshold, then that family and every individual in it is considered in poverty" (United States Census Bureau, 2015, para. 1).

In 2015 the poverty threshold for a family of 4 was $\$ 24,259$. There are 48 thresholds, each depicting a different family configuration and poverty threshold. The Department of Health and Human Services uses a simplified version of these thresholds called poverty guidelines to determine eligibility by income for the National School Lunch and Breakfast Program and other social services (Institute for Research on Poverty, 2014). The poverty guideline for a family of 4 in 2015 was $\$ 25,250$ (United States Department of Health and Human Services, Poverty, 2015).

\section{Title I}

One of the purposes in the Title I Act is "closing the achievement gap between high and low-performing children, especially the achievement gaps between minority and nonminority students, and between disadvantaged children and their more advantaged peers" (USDE, 2004a, Statement of Purpose, para. 2).

Title I, Part A (Title I) of the Elementary and Secondary Education Act, as amended (ESEA) provides financial assistance to local educational agencies (LEAs) and schools with high numbers or high percentages of children from low-income families to help ensure that all children meet challenging state academic standards. (USDE, 2014, Program Description, para. 1) 
Local education agencies identify attendance areas that qualify using one or several poverty measures and then determine which schools will be given Title I funds and whether each school in an attendance area qualifies as a schoolwide project or a targeted school project. Local education agencies must serve attendance areas and schools according to their percentages of poor children. A school must have at least $40 \%$ of its enrolled students who qualify as poor to be eligible for a schoolwide project that then allows the school to offer services to all children (USDE, 2014). Schools that do not have $40 \%$ or who choose not to have a schoolwide project are targeted assistance schools and "...must focus Title I services on children who are failing, or most at risk of failing, to meet state academic standards" (USDE, 2014, Program Description, para 3). These schools must design a program in conjunction with the district staff, school staff, and parents that offers research based initiatives and parental involvement activities (USDE, 2014).

There are 344Title I public schools in West Virginia. Two are targeted assistance schools while the rest are all schoolwide projects (WVDE, 2014b). This research is limited to teachers and Title I specialists in the 344 public Title I schools in West Virginia.

\section{Poverty and Achievement}

Several studies have demonstrated the devastating effect of poverty on students' academic achievement (Jensen, 2009; Reardon, 2011). In 1966 the Coleman Report demonstrated the link between family socioeconomic status and student achievement (Coleman et al.1966).

Using data from over 600,000 students and teachers across the country, the researchers found that academic achievement was less related to the quality of a student's school, and 
more related to the social composition of the school, the student's sense of control of his environment and future, the verbal skills of teachers, and the student's family background. (Kiviat, 2000, para. 6)

The report named after James Coleman, the Chief Investigator, is widely considered to be the most important educational research of the $20^{\text {th }}$ century and was at the forefront of studying the social context of education. Coleman looked not just at input factors but output factors such as test scores for his conclusions (Kiviat, 2000).

A later 20 year study of Title I funding and education reform found that parents' educational level and family income were potent factors in student achievement (Drazen, 1992). Drazen (1992) found a correlation of .315 between family income and achievement in 116 studies conducted by Karl White (White, 1982). In another study of 20,000 Title I students over two years, Stephen Schellenberg (1998) studied the effects of poor neighborhoods on the achievement of students and concluded that students who came from more affluent areas consistently had higher test scores and less absenteeism.

Children from low-income families enter school with different skills and behaviors than high SES students. Duncan and Magnunson (2011) reviewed the Kindergarten Cohort in the Early Childhood Longitudinal Survey in the National Center for Education Statistics (n.d.), and the National Longitudinal Survey of Youth, Child, and Young Adults (National Longitudinal Surveys, n.d.). Their findings demonstrated that low socioeconomic subset (SES) children scored lower than their peers on kindergarten entry skills: .3 standard deviations lower on math entry level skills; .67 standard deviations below on attention skills; and .25 standard deviations lower on anti-social skills. These gaps do not shrink while the students are in elementary school and the 
anti-social behavior of poor children nearly doubles during this time (Duncan \& Magnunson, 2011).

The achievement gap for poor children has not diminished for the low socioeconomic subset over the years. "The achievement gap between children from high and low-income families is roughly 30 to 40 percent larger among children born in 2001 than those born twentyfive years earlier" (Reardon, 2011, p. 91). High income in this instance is defined as families in the top $90^{\text {th }}$ percentile in income and low-income is those families at the bottom 10th percentile (Reardon, 2011).

Socioeconomic status correlates positively with good parenting such as reading to children, engaging in activities together, and providing background building experiences (Lugalia, 2003). These parenting practices improve academic achievement (DeGarmo, Forgatch, \& Martinez, 1999). Unfortunately, the converse is also true. The chronic stress of poverty impairs parenting skills, and disengaged or negative parenting, in turn, impairs children's school performance.

Education and educators cannot address all of the underlying problems of poverty, but they need to be aware that poverty can affect student achievement and that there are initiatives which may mitigate those effects.

\section{Primary Risk Factors for the Low Socioeconomic Subset Child}

Eric Jensen (2009) lists four primary risk factors that affect students and families in poverty: emotional and social challenges, acute and chronic stressors, cognitive lags, and health and safety issues. Thirty-five percent of families living in poverty experience many events within these primary risk factor groups as compared to major stressful events experienced by five 
percent of well-off families (Jensen, 2009). DNA accounts for 30\% to $50 \%$ of a child's development, but socioeconomic factors like acute and chronic stressors affect the remaining $50 \%$ to $70 \%$ (Saudino, 2005).

Emotional and social challenges. Poor children are affected by emotional and social challenges that affect their ability to achieve. One major challenge is often the lack of a nurturing home life where there is stability, predictability, nurturing, unconditional love, and opportunities for enrichment. Low-income families move often, work longer hours, work during unconventional hours, often hold more than one job or are unemployed, and have parents who often have a substandard education. These families often move overnight, avoiding the rent, eviction, or adverse relationships, and even dangerous situations. The children change schools frequently, are more likely to be ill, and are more likely to have an incarcerated or unemployed parent or guardian (Ravitch, 2013). The negative effects of this change, disruption, and uncertainty cause the development of adverse adaptive responses that can include impulsivity, impatience, acting out, inappropriate responses, and lack of empathy for others (Jensen, 2009).

Low-income parents and caregivers who tend to be overworked, exhausted, and dealing with stressful events themselves often use harsh and authoritarian discipline, passing on the types of parenting that they experienced (Evans, 2004). In an in-depth study of working families and middle class families, Annette Laureau found that working families believed that physical punishment was an acceptable way to discipline their children. "Most important, when the mother felt her son was not sufficiently responsive, she found the force of physical discipline to be a valuable resource" (Laureau, p. 229, 2011). Laureau did not find any evidence of physical punishment among the middle class families that she studied. 
Poor children spend more time watching television and less time outdoors or in extracurricular activities. In 2003 the U.S. Census Bureau reported differences between poor and non-poor children in the following categories: participation in extracurricular sports, clubs, and extra lessons; family reading practices; and television rules (Lugalia, 2003). As a result, lowincome children spend less time developing relationships with adults in enriching and background building activities. They never learn how to engage appropriately with others (Szewcyk-Sokolowski, Bost, \& Wainwright, 2005). These children tend to develop psychiatric disturbances and have a high rate of social maladaptation (McCoy, Frick, Loney, \& Ellis, 1999).

Children are born with only six emotions: joy, anger, surprise, disgust, sadness, and fear. All other emotions such as humility, forgiveness, empathy, optimism, and patience are taught and modeled by adults (Jensen, 2009). Poor parents who are dealing with unpaid bills, unemployment, and the many stresses of poverty often lack the internal and external resources needed to successfully model and teach these emotions. If children are not taught these emotions during their infancy, the school must model and teach them, or children will not be able to use appropriate behaviors (Jensen, 2009). Many poor students who lack these modeled and taught emotions will seek out social acceptance and status in unacceptable ways, and they will look for relationships without a reference from which to draw. Meeting these social needs and showing students how to make good choices becomes important for the student and the school (Harris, 2006).

Children who do not have secure, stable environments and relationships and resultant optimal brain growth at the beginning of life continue to struggle with insecurity and will be more apt to face depression, teen motherhood, and difficulty with relationships (Van Ijzendoorn, Vereijken, Bakermans-Kranenburg, \& Riksen-Walreven, 2004). Conversely, "In homes with 
adequate resources, children get advantages that enable them to arrive in school healthy and ready to learn" (Ravitch, 2013, p.6).

Chronic and acute stressors. Chronic and acute stressors are more prevalent for poor children and cause a variety of problems including impaired concentration, impaired memory, impaired cognitive functioning, high absenteeism, diminished social skills, high levels of depression, and poor behavior control (Almeida, Neupert, Banks, \& Serido, 2005; Jensen, 2009). These stressors also contribute to a lack of impulse control, a feeling of hopelessness, and risky decision making (Jensen, 2009). Stressors that affect poor children include evictions, having utilities turned off, living without major appliances, poor day care and schools, and lack of supervision (Jensen, 2009; Lichter, 1997).

Acute stress is severe stress such as abuse, neglect, malnutrition, drug use, trauma, and lack of enrichment. Chronic stress is high stress that is long term (Jensen, 2009). Acute and chronic stresses not only affect children emotionally but have dramatic physical effects as well. "A stressed neuron generates a weaker signal, handles less blood flow, processes less oxygen, and extends fewer connective branches to nearby cells" (Jensen, 2009, p. 25). Chronic or acute stress can actually shrink the brain's frontal lobe neurons. It can have a lasting effect on the amygdala and the hippocampal volume and function. These alterations in brain development can lead to impaired learning and a lack of control over emotions, social functioning, empathy, and other important factors needed for healthy emotional and social development. It puts children at risk even into adulthood for mental illness and may cause impaired long term memory, lack of concentration, and inattentiveness, all of which may eventually affect future job performance (Nelson \& Sheridan, 2011). 
Cognitive lags. Poverty affects the brain and cognitive development (Gottfried, A. W. Gottfried, A. E., Bathurst, Guerin, \& Parramore, 2009; Jensen, 2009; Ravitch, 2013). Socioeconomic status is strongly associated with a number of indices of children's cognitive ability including IQ, achievement test scores, grade retention rates, and literacy (Baydar, BrooksGunn, \& Furstenberg, 1993; Brooks-Gunn, Guo, \& Furstenberg, 1993; Liaw \& Brooks-Gunn, 1994; Smith, Brooks-Gunn, \& Klebanov, 1997). Forty percent of children who live in chronic poverty have been shown to have deficiencies by age three in at least two areas of cognitive functioning that include language and emotional responsiveness (Bradley et al., 1994). A study found significant differences in neurocognitive areas between lower income and higher income students. Higher socioeconomic students did better in performance tasks, language, memory systems, working memory, and cognitive control (Farah et al., 2006).

Health and safety issues. Poor children's health is affected before they are born. Prenatal care and those factors that affect the baby before birth such as toxins, drugs, alcohol, tobacco use, and parental stress have received more attention in recent years with the emergence of epigenetics which studies these negative influences on the fetus (Jensen, 2009). These studies show that poor children often arrive in the world smaller, less healthy, and with strong negative influences on how their genes function (Rutter, Moffitt, \& Caspi, 2006). The United States has a high rate of women who do not get prenatal care. This is especially true for women below the federal poverty level (Ravitch, 2013). This lack of prenatal care or even delays in obtaining care poses risks for both mother and fetus and often results in premature births and infant and maternal fatalities. Premature babies have a greater likelihood of having disabilities, behavioral problems and other health complications (Kiely \& Kogan, 1994). 
Poor children are more likely to live in dangerous neighborhoods with higher levels of crime and drug activity. Their nutrition, air, and water quality can be affected. This affects student achievement (Bradley \& Corwin, 2002; Gewertz, 2007; Jensen, 2009; McCord \& Freeman, 1990; Ravitch, 2013; Tileston \& Darling, 2008). Poor families and their children have poorer health (Sapolsky, 2005). In fact, the poorer the child, the greater are the risks of asthma (Gottleib, Beiser, \& O’Conner, 2002); ear infections and loss of hearing (Menyuk, 1980); respiratory infections (Simoes, 2003); and psychological distress (Matte \& Jacobs, 2000). Poor children are more prone to suffer from lead poisoning, measles, and tuberculosis and, in many inner cities, have death rates higher than third world countries (McCord \& Freeman, 1990). These health and safety issues play out in increased absenteeism, tardiness, psychological problems (Evans, Wells, \& Moch, 2003), and decreased IQ scores (Schwartz, 1994).

\section{The Failure of Educational Reforms}

National educational reforms that have targeted poor children have not been successful in narrowing the achievement gap in the United States. Jack Jennings, former President and CEO of the Center on Education Policy, identified three major reform movements in the United States that have failed: equity-based reforms, school choice-based reforms, and standards-based reforms which evolved into test-driven accountability reforms found in the No Child Left Behind Act (Jennings, 2012). The issue of school finance reform is another example of reform aimed at equalizing resources for poor children but this has been the state's responsibility.

Equity-based reforms. In the 1960s and 1970s the federal government provided equity based programs that were aimed at equalizing resources and opportunities including the Civil Rights Act of 1964, President Johnson's War on Poverty, Head Start, federal nutrition programs, 
and Title I. Fueled by the strong Civil Rights Movement of the time, these equity-based education reforms were targeted attempts to provide help to poor schools that states could not or would not address and to provide equity for major racial and ethnic groups, children with disabilities, students with limited English proficiency, economically disadvantaged children, and women and girls. The Civil Rights Act of 1964 made discrimination against minorities illegal. Lyndon Johnson's Great Society and War on Poverty addressed equity, especially for poor children, through entitlements such as Title I and Head Start (Jennings, 2012). The Individuals with Disabilities Education Act (IDEA) and the U.S. Supreme Court ruling known as the LAU remedies, Lau v. Nichols (1974), said that children could not be deprived of an education because of disabilities or limited English proficiency (Jennings, 2012).

Civil rights. The Civil Rights movement strengthened when the U.S. Supreme Court decision in Brown v. Board (1954) said that segregated schools were inherently unequal. Today according to some researchers the Black/White achievement gap has narrowed significantly since prior to the 1950s. Larry Hedges and Amy Nowell (1998) studied major national surveys of high school students and concluded that the Black/White test score gap has narrowed dramatically. They believed this to be due, in part, to a combination of factors including desegregation, smaller class size, and the impact of anti-poverty measures from the War on Poverty. It seems that the narrowing of the Black/White test score gap was a result of the Civil Rights Act, the U.S Supreme Court ruling, and Johnson's War on Poverty. However, the impact on the Black/White achievement gap was not true for the low SES that consists of a majority of White students (Grissmer, Flanagan, \& Williamson, 1998). Although the African American percentage of those in poverty in 2010 was $27.4 \%$ compared to Whites with $13 \%$, African 
Americans represent a smaller number of the poor: $10,675,000$ as compared to $31,650,000$ Whites (United States Census Bureau, 2011).

Head Start. Passed in 1965, Head Start began the nation's longest running entitlement program aimed at helping children to overcome problems caused by poverty. When Head Start was enacted, there were few programs of this scope to address early education for poor children. Several studies have been conducted about its success in academic and cognitive gains. In one series of studies White and Latino students did better over time on tests and other achievement indicators when compared to children who did not attend Head Start. This research also indicated that there were benefits for poor children in other areas, especially immunization. Cognitive gains, however, were not sustained over time for all children, especially for Black children (Currie \& Thomas, 1995; Currie \& Duncan, 1998). Despite these mixed reviews, the program continues to receive federal and popular support, and, in a recent study done by the Brookings Institute, the authors summarized that Head Start does have long-term benefits for children (Ludwig, Phillips, \& Society for Research in Child Development, 2007). However, these gains may not be evidenced in current achievement testing.

Federal nutrition programs. Federal food programs were also expanded in the 1960s and, according to a Georgetown University study, improved students' overall educational attainment by a full year (Sparks, 2014). The National School Breakfast Program was begun as a pilot in 1966 and then later became a permanent program (United States Department of Agriculture, 2014).

Title I. The 1965 Elementary and Secondary Education Act Title I targeted money to poor children. It provided poor schools with additional resources in reading and math. In a report 
by the Policy and Program Studies Service, Office of Planning, Evaluation and Policy Development prepared for the National Center for Education Evaluation and Regional Assistance, Institute of Education Sciences, Title I students in schoolwide programs across 36 states had the following results. "The long-term achievement trends measured by the long-term trend of National Assessment of Educational Progress showed significant gains for all three age groups tested in mathematics and for 9-year-olds and 13-year-olds in mathematics" (Stullich, Eisner, \& McCreary, 2007, p. xxiv). The achievement gap between low-income and all students showed a one to three percent reduction (Stullich, Eisner, \& McCreary, 2007).

Shelley Drazen (1992) suggested that Title I and other compensatory funds often were misdirected and misused. The funding also never reached the amount needed to address the high need of poor schools and students, but the Title I program is still an important source of funding for special programs, increased resources, additional staff, and parent involvement in high poverty schools (Jennings, 2000).

IDEA. The Individuals with Disabilities Education Act (IDEA) was passed in 1975 and requires districts to pay for services for children with disabilities and to require procedural safeguards so that parents are part of the process in determining services. All children with disabilities must be served regardless of the cost or the ability of the district to pay (Jennings, 2012).

Summary. The education reforms based on equity during these years did provide targeted equity and protections but did not address the greater inequities of rich and poor schools and the neighborhood and living conditions of the poor. Minorities, who make up a significant part of the disadvantaged subset, have made more substantial gains over time with the 
Black/White achievement gap reducing, but poor children who are still predominantly White have not. Equity-based reforms were never adequately funded and addressed external factors only, without looking within the educational system at systemic reform and at societal and neighborhood conditions (Jennings, 2012).

School choice reforms. A reform that has run concurrently with the standards movement is the idea that the schools are not doing a good job and that business and industry can do better. Characterized by both vouchers and charter schools, this school choice movement emphasizes allowing parents to move children out of their low-performing schools into other public, private, or charter schools.

Vouchers. School vouchers are sometimes referred to as opportunity scholarships. These vouchers are given to students to attend private schools instead of public schools. Legislatures generally set parameters and guidelines for recipients. Often they are for low-income groups, foster children, military families, or students attending low-performing schools. The first voucher system appeared in Wisconsin allowing poor families the ability to use vouchers to attend schools of their choice. Ohio, Florida, Indiana, and Washington, D.C. also have used voucher systems (National Conference of State Legislatures, 2014). However, voucher initiatives, met with little widespread success and initiatives, have been defeated in Florida, Maryland, Michigan, Colorado, California, Washington, and Michigan. The U.S. Department of Education analyzed the D.C. voucher system and concluded that there was no positive impact on achievement for students using vouchers and those students actually had less access to essential services such as the nurse, tutors, learning support, and counselors. It reported that $54 \%$ of children left after three years (USDE, 2010). 
Charter schools. Charters, on the other hand, continue to expand. Charter schools are publicly funded elementary or secondary schools that have been freed from some of the rules, regulations, and statutes that apply to other public schools, in exchange for some type of accountability for producing certain results, which are set forth in each charter school's charter (Sauter, 1993). States have the authority to set up charter regulations or to deny them entirely. Because charter schools are so diverse in their charters, populations served, and type of organization, it is difficult to ascertain the impact on low-income children and whether this reform has helped their achievement. However, the U.S. Department of Education did find in a study from 1999-2002 that charter schools were "...more likely to serve minority and lowincome students than traditional public schools but less likely to serve students in special education" (USDE, 2004b, Highlights, para. 2). The study also found that in five case studies charter schools did not do better than public schools in meeting state performance standards (USDE, 2004b). A 2010 study of 36 charter schools found that they did have a significant impact on math scores for low-income children in year two of the study. Scores did improve in reading, but they were not statistically significant (Gleason, Clark, Tuttle, \& Dwoyer, 2010). The Urban Charter School Study conducted by the Center for Research on Education Outcomes covered 41 urban communities in 22 states and did find gains in additional days of learning growth in math and reading.

The study found that the typical student in an urban charter school receives the equivalent of 40 additional days of learning growth (0.055 s.d.'s) in math and 28 days of additional growth (0.039 s.d.'s) in reading compared to their matched peers in TPS. The results were found to be positive for nearly all student subgroups, but especially strong for 
students who are minority and in poverty, who are a significant portion of the urban student population. (Center for Research on Education Outcomes, 2015, para. 4)

Summary. The school choice movement did not significantly affect how poor students achieve. Vouchers and charter schools have not been proven to provide any substantial help. The low SES achievement gap persists.

Standards-based reforms. In April of 1983 A Nation at Risk was published under President Ronald Regan who had commissioned then Secretary of Education Terrence Bell to produce a report on education. This report warned that American students were not achieving and falling behind their peers in other countries, and there was, "a rising tide of mediocrity" assailing education in the United States (The National Commission on Excellence in Education, 1983; USDE, 1983). Emphasis would now be on higher standards, better teachers, better pay for teachers, and higher requirements for graduation, all areas that those in power believed were causing the problem. No blame was placed on businesses, wealthy individuals, elected officials or philanthropic organizations (Berliner \& Glass, 2014). Teach for America became a multimillion dollar non-profit by advocating a new teacher credentialing process that recruited people who then served two years and would reduce the achievement gaps. Business and industry were encouraged to be involved in education. The emphasis was on more time, more subject matter, and more standards. Ability grouping became popular (Berliner \& Biddle, 1995).

Berliner and Biddle in The Manufactured Crisis challenged the statements that formed the basis for the criticisms in A Nation at Risk. "If we go by the evidence, despite greatly expanded student enrollment, the average high school and college student is doing as well as, or perhaps slightly better than, that student did in previous years" (Berliner \& Biddle, 1995, p. 64). 
American workers are competitive in production, technological innovations, contribute to a creative and vibrant culture, and participate in the largest economy in the world (Ravitch, 2013).

The efforts following the report of A Nation at Risk did not translate into a narrowing of achievement gaps for the poor. According to reformers, the basis for the reforms was not legitimate. The problems with the comparison of test scores internally and externally has to do with opportunity deficits, not education deficits (Ladson-Billings, 2006). It also had to do with sampling biases, differences in curricula from other countries, ignoring studies in which U.S. students did well, and misleading results based on the wide range of poor to good schools (Berliner \& Glass, 2014). Overall, the report, A Nation at Risk, on which many of the reforms were based was not accurate in its portrayal of the problems or the solutions (Berliner \& Glass, 2014; Ravitch, 2013).

Test-based accountability. The publication of $A$ Nation at Risk began a dialogue about how to improve education. The immediate reaction to the reported crisis was to require "...better curriculum standards, higher graduation requirements, better teacher training, higher teacher pay, and other customary improvements" (Ravitch, 2013, p. 10). However, testing, choice and accountability were not included as initiatives. President George H. W. Bush attempted to nationalize standards for education using the example of the National Council of Teachers of Mathematics. President Bill Clinton also advocated for standards, but this was more directed at state initiatives that emphasized student proficiency. After failing to make progress on national standards, the Clinton administration published Goals 2000. Both set the stage for George W Bush's No Child Left Behind Act (Jennings, 2012) which would add accountability, testing, and the idea of choice through charters and privatization (Ravitch, 2013). 
The No Child Left Behind Act enjoyed bi-partisan support with general agreement that all children should be achieving and that low-income, special education, limited English proficiency, and major ethnic and racial groups should be proficient in reading, math, science, and social studies. Academic standards, no longer the driving force in reform, were replaced by test-driven accountability. The No Child Left Behind law targeted Title I schools since they received federal money. Schools were required to show results across subsets of students. All subsets were required to make progress to proficiency with failures resulting in a series of progressively harsher penalties that could result in students transferring out and even the elimination of staff and a reconstitution of schools. All students were required to reach proficiency by 2014, a goal which many thought was unrealistic. Schools that did not meet proficiency were labeled as failing schools. Standards also differed across states. By 2011 almost one-half of the schools in the nation had not met the goals of proficiency (Jennings, 2012).

The Race to the Top was the next step in the accountability ladder. In 2008 President Obama set aside $\$ 5$ billion for a competition among states in which some vied for an award based on creating new standards, more charter schools, linking test scores to teacher evaluations, and reconstituting low-performing schools. Once again, low-performing schools could be subjected to staff firings, school closings, and other dramatic changes. The Bill \& Melinda Gates Foundation gave grants to select states to hire professional grant writers, thereby giving some states and districts a competitive edge in the Race to the Top application process. Outside consultants and corporations became the recipients of the dollars that were to direct education reform. The risk factors of children in poverty earlier identified were seldom part of the dialogue. Tests were the primary measure of the success of teachers, schools, and districts (Ravitch, 2013). 
Test-driven reform appears headed for failure. It relies too heavily on test scores and has no research or educational base (Ravitch, 2013; Berliner \& Glass, 2014).

Summary. The standards movement continues to bring little help to low socioeconomic children. States are beginning to opt out of mandatory state testing practices as parents and educators see the effects on young people, teachers, and schools, all of whom are judged on several days of testing rather than a composite of their learning. However, this movement has contributed to overall student success by creating clearer expectations and the same expectations for all students in a state. The current common core movement which creates national common core standards is being adopted by many states (Jennings, 2012).

School funding reforms. The final reform movement is school funding that is a state responsibility. Simply put, wealthy neighborhoods have more money to spend on students than poorer neighborhoods. Most state constitutions address the idea that all children have the right to an equal opportunity for education in grades K-12. However, that is seldom the case in actual practice, and disparities exist between states, districts, and schools in the same district. Often states will mandate a minimum level of funding and allow local districts to add on resources through special levies and bond sales (Berliner \& Glass, 2014).

In 2010 there were 13 states that had school finance cases pending. Most states have had some sort of school finance case in litigation. Generally, the courts favor the plaintiffs but little change in equity occurs (Berliner \& Glass, 2014).

The case Pauley et al. v Bailey et al. (1982) in West Virginia is a representative case of the inequities of school funding and educational resources in the United States, and the precedent setting solutions that resulted. In 1971 Jane Pauley sued the West Virginian State Department of 
Education because she claimed that her children attended substandard schools funded by a failed funding system. She contended that the children of Lincoln County were not getting an equal education due to its lack of resources and tax base and the pervasive poverty of the area. She believed that these children would not receive an education commensurate with that of more affluent counties. The case focused on the "thorough and efficient" system of education guaranteed in the West Virginia state constitution (Hazi, 1985). This began a decade long debate on how to equalize opportunity, resources, and funding. Judge Arthur Recht ruled that the state was obligated to not only rectify the disproportionate resources of those children, but to actually increase their resources over other more affluent counties (Hazi, 1985). The West Virginia case “...set the precedent that the courts-not educators-have the power to establish quality (not minimum) standards for education in a state" (Hazi, 1983, p. 68).

Summary. Attempts to equalize school funding have met with little success. School finance cases have focused on state constitutional provisions guaranteeing equal opportunity for all children. Districts have often responded with minimal thresholds and then allowed districts to pass special levies and bonds. In the West Virginia case, Pauley et al. v Bailey et al. (1982) the judge responded by mapping out a very detailed set of remedies for the State Department of Education.

\section{Initiatives}

State legislatures and departments of education along with local education officials and other policy makers have proposed many classroom initiatives to address academic achievement in the low socioeconomic subset. Initiatives in this study are strategies and reforms that are intended to address the causes for low achievement in poor children. These reform initiatives 
include those that have been tested for success and those that have been proposed and/or used without a significant accounting of their effectiveness. These reform initiatives are divided into four categories: 1) extended time which includes preschool, after school programs, and adding minutes to the school day or days to the school year; 2) classroom strategies; 3) supplemental services; and 4) other influences on students' academic success and achievement.

Extended learning time. Extended learning time includes preschool, after school programs, and adding minutes to the school day or days to the school year. Both preschool and after school programs have proven to be successful in addressing factors that contribute to the low achievement of poor children. Expanded learning time in which districts add time to the day or the calendar has mixed reviews.

Preschool. Preschool is one strategy that has been used to give poor children the ability to enter first grade with the skills and language ability of their more affluent peers. Quality preschool programs provide early interventions, especially in literacy and background building that are essential for language development. Many believe that it is important to provide early childhood education and programs since this is a time when children experience critical growth in “... cognitive, emotional, social, and physical development” (Karoly, 2001, p. 315). These programs also usually include parenting classes, home visits, and day care services.

Head Start is one such program. Started in 1965 as one of the tenets of Johnson's War on Poverty, numerous studies have produced mixed reviews on its effectiveness. Karoly (2001) listed the following results in a series of studies by Janet Currie and Duncan (Grace, Thomas, \& Currie, 2000).

- Whites and Latinos improved significantly in test scores and school attainment. 
- Initial gains for Black children disappeared with some thought that this was due to inferior schools that they later attended.

- Black and White children had higher rates of immunization.

- There were no changes in long-term nutritional benefits.

- Long term cognitive gains eventually faded. (Currie \& Thomas, 1995, 1998, 2000)

Karoly (2001) also examined the effects of these other early childhood education programs in the United States. In the Carolina Abecedarian Program in North Carolina participants had higher cognitive test scores through age 21 and showed significant decreases in special education identification and grade retention; higher rates of high school graduation and achievement test scores; and a dramatic improvement in teen pregnancy rates and spacing of births (Frank Porter Graham Child Development Institute, 2014). Perry Preschool Project participants in Ypsilanti, Michigan, did better economically, earning 59\% higher incomes than a control group. They experienced lower incidences of delinquency and had higher rates of high school graduation and employment (Schweinhart, 2005). The Prenatal/Early Infancy Project in Elmira, New York, showed significant improvement in birth rates and spacing, parent time spent with children, and economic dependency (Frank Porter Graham Child Development Institute, 2014).

After school programs. After school programs provide safe places in unsafe neighborhoods, help working parents, and contribute to academic success. They can run well into the evening and sometimes charge fees. These programs can be run by school districts, nonprofit organizations, national organizations such as the Boys and Girls Club, or by for-profit entities. They may connect to the regular school day but can also be independent of the school. 
The Harvard Research Project looked at 10 years of research on afterschool programs. They concluded that afterschool programs can improve academic achievement, improve social and developmental outcomes, and contribute to healthier lifestyles including avoidance of drug and alcohol abuse, among other indicators. Successful programs were cited including the LA BEST, an after school initiative project. "Higher levels of participation in LA BEST led to better subsequent school attendance, which in turn, related to higher academic achievement on standardized tests of mathematics, reading, and language arts" (Little, Wimer, Weiss, \& Harvard Family Research Project, 2008, p. 5). A meta-analysis of 35 studies of after school programs in urban, suburban, and rural locations showed significant positive effects on reading and math achievement (Laurer et al., 2006).

Adding minutes, hours, and/or days. In these district-run extended day or expanded learning time programs, the regular school day and/or year is extended, providing more time for the district to provide instruction. Studies are mixed about the advantages of extending the school day and/or year with issues that include funding and information retention.

- A four year study of expanded learning time (ELT) in Massachusetts showed little difference between schools that used ELT and those that did not (Boulay et al., 2007).

- A Mexican study showed that extending the year by as much as 40 days had little effect on low SES students (Crawford, 2013).

- Research is mixed about the results of adding minutes and/or days but it is clear that it is the quality of extra time and not the length that is important (Silva, 2012).

Classroom strategies. Classroom strategies proposed to increase achievement for lowincome children have included instituting small class sizes, encouraging teachers to hold high 
expectations for all children, teaching children how to cope with adversity, and increasing or adding programming in physical activity and the arts. Testing is also a strategy that is used to focus on student achievement and low-performing areas and students. High stakes standardized testing is summative in nature, looks at end results, and makes comparisons among various groups, students, schools, and even districts. Formative testing uses on-going assessments to identify student weaknesses for the purpose of remediation. Some school systems also use differentiated instruction and Response to Intervention (RTI) to address low achieving students.

Class size. Class size is a significant predictor of achievement for students from lowincome families and can show increases in achievement with even three fewer students per class (Merritt, et al., 2011). The Student-Teacher Achievement Ratio (STAR) Project first investigated the effect of small class size on student achievement with over 6,000 Tennessee primary students in 1985 through 1989. "The study found a consistent and significant benefit of small classes for all students, with the greatest advantages for minority, inner-city students from low SES backgrounds" (Pate-Bain, Boyd-Zaharias, Cain, Word \& Binkley, 1997, p. 1).

Teachers' high expectations and beliefs. Teachers' high expectations and beliefs directly influence students' academic experiences. Carol Dweck in her studies of students' mindsets found that "... students who believed their intelligence could be developed (a growth mindset) outperformed those who believed their intelligence was fixed (a fixed mindset)" (Dweck, 2015, para. 2).

In studies by Rosenthal and Jacobsen $(1968,1992)$, students in the experimental group in which teachers believed that the students had the ability to excel did just that. The experimental 
group gained 27.4 IQ points in first grade and 4 points more on IQ than the control group throughout their six years at the school.

Simply put, when teachers expect students to do well and show intellectual growth, they do; when teachers do not have such expectations, performance and growth are not so encouraged and may, in fact, be discouraged in a variety of ways. (Rhem, 1999, p.1)

Teaching resiliency and coping skills. Teaching resiliency, coping skills, and stress relieving techniques to poor students helps students cope with acute and chronic stress. Resiliency refers to the ability of children in poverty to successfully use skills to adapt and make meaning for themselves. Through this type of initiative students learn how to begin and finish projects, resisting the negative messages about themselves while developing an autonomy that allows them to distance themselves from negative aspects of their lives (Bernard, 1996). Although in many studies, coping skills and resilience are discussed together they are different. Coping is defined as using skills to respond to stress. Resilience is the successful use of these skills. Rosen, Glennie, Dalton, Lennon, and Bozick (2010) examined 21 studies using the constructs of resilience, coping, and academic success. Eight of the studies on resilient students showed increased academic achievement as measured by various instruments including SAT scores, NAEP scores, Woodcock Johnson Achievement scores, and GPA.

Teaching resilience and coping skills includes teaching appropriate responses, providing students with a locus of control, increasing students' efficacy, recognizing and respecting relationships, incorporating students' different cultures and backgrounds, and teaching planning and organization and cause and effect (Tileston \& Darling, 2008). In How Children Succeed (2012) Paul Tough explains the importance of teaching these resilience and coping skills through an intentional process. In the Tools of the Mind curriculum children are taught how to cope, how 
to focus, how to manage their emotions, organize their thoughts, and control their impulses. The emphasis on reading and math skills is replaced with an emphasis on self-regulation (Tough, 2012). Low SES students who are taught resiliency have a more positive outlook toward school and better self-esteem. Borman, Rachuba and the Center for Research on the Education of Students Placed at Risk reported that "...the most powerful school characteristics for promoting resiliency were represented by the supportive school-community model, which, unlike the other school models, included elements that actively shielded children from adversity" (Borman, Rachuba, \& Center for Research, 2001, p. 1). Werner and Smith studied the power of teaching resiliency and coping skills. In summarizing their 35-year study of resiliency in childhood, they found that those components that contributed to the ability to cope effectively with life stresses were a sense of coherence, confidence that their environment was predictable, and the belief that everything would probably work out (1982). Those students “...succeeded in school, managed home and social life well, and set realistic educational and vocational goals and expectations for themselves" (Werner \& Smith, 1982, p. 11). Factors that contributed appeared to be protective factors in themselves, their family and their community. This included mentoring, independence, structure in the family, and a strong faith and belief system (Werner \& Smith, 1982).

In the San Francisco Unified Schools students have 15 minutes at the beginning and end of each day for quiet time. The students and staff practice breathing and meditation. "Many of San Francisco's schools report reductions in truancy, behavioral referrals, and suspensions after implementing Quiet Time" (Esposito, 2014, para. 8). "In summary, stress is damaging to learning. There's no one-size fits-all or quick-fix to reduce the environmental toxicity facing many of our next generation" (Esposito, 2014, para. 37). 
Increased time in physical education. Increasing the amount of time in physical education classes, providing physical activities in the classroom, and providing recess time has positive effects on cognitive skills and attitudes, academic behavior, and academic achievement (Hellmich, 2010). The United States Department of Health and Human Services conducted a study of the effects of physical education on academics. "Across all 50 sites, there were a total of 251 associations [positive outcomes] between physical activity and academic performance" (Center for Disease Control and Prevention, 2010, p. 5). "Collectively, these results suggest that physical activity is...positively related to academic performance $(50.5 \%$ of the associations summarized)" (Center for Disease Control, 2010, p. 28). The studies included school-based recess time, extracurricular physical activity, and physical activity breaks.

Arts education. Arts education is used for a range of desirable outcomes including math ability, memory skills, and reading. Training in music has been found to improve cognitive memory by making strategic changes in the brain where retrievable memories are maintained (Jonides, 2008). "Education in visual arts also improves math calculation" (Wandell, Dougherty, Ben-Shacar, \& Deutsch, 2008, p. 52). In a 2011 study of 11,000 students and 500 teachers in Bentonville, Arkansas who participated in museum tours, a strong causal relationship was established between the arts and many desirable outcomes. "Students who, by lottery, were selected to visit the museum on a field trip demonstrated stronger critical thinking skills, displayed higher levels of social tolerance, exhibited greater historical empathy, and developed a taste for art museums and cultural institutions" (Kisida, Greene \& Bowen, 2013, para.3).

Summative high-stakes standardized testing. High-stakes standardized testing which is linked to state and national standards has been a popular reform to increase achievement of all students. These tests are typically standardized and are marketed by testing companies. Although 
they can be used in a formative way, these tests are usually summative and used to compare groups, students, and teachers. In a study by Laura-Lee Kearns (2011) of 16 "at risk" youth who had failed the standardized Ontario Secondary Literacy Test, students questioned themselves and their abilities and felt inferior and, they sometimes challenged the idea that they were failures, essentially altering their vision of themselves. Diane Ravitch in Reign of Error (2013) points to testing companies where scorers make hurried and subjective decisions about tests. She also criticizes the use of tests to evaluate schools and teachers and believes there is a need to look at more appropriate assessments. "Our standards and our expectations are higher and more complex than the skills needed to pass a standardized test" (Ravitch, 2013, p. 273). Both Timar (Timar \& Maxwell-Jolly, 2012) and Berliner and Glass (2014) believe standardized testing and the resultant achievement gap of the low socioeconomic children are in large part caused by poverty which affects students before they arrive at school and throughout their school career.

Formative assessment. Formative testing is primarily used to diagnose problems or check progress. A New York City model in which teachers used formative performance assessment for evaluation showed better long term benefits than summative testing for students including fewer dropouts and more students attending and finishing college. The tests are created by teachers and include performance tasks (New York Performance Standards Consortium, 2014). Two studies also showed increased achievement with the use of formative testing (Carpenter, 1991; Fuchs, 1989).

Response to intervention. RTI is a three tiered approach to helping struggling readers through a series of interventions based on research proven programs. 
The essential elements of an RTI approach are: proven scientific research-based instruction and interventions in general education; monitoring and measuring student progress in response to the instruction and intervention; and using these measures of student progress to shape instruction and make educational decisions. (Klotz \& Canter, 2007, p. 1)

In a study by the Society for Research on Educational Effectiveness, a leveled literacy intervention program positively impacted student achievement especially for disadvantaged youth (Ransford-Kaldon, Flynt \& Ross, 2011). "Robust effects were found on LLI (Leveled Learning Intervention) across all grade levels for students who received LLI" (Ransford et al., 2011, p. A-3).

Differentiated instruction. Differentiated instruction was defined by Diane Ravitch in EdSpeak: A Glossary of Education Terms, Phrases, Buzzwords, and Jargon (2007).

In practice, it involves offering several different learning experiences in response to students' varied needs. Educators may vary learning activities and materials by difficulty, so as to challenge students at different readiness levels; by topic, in response to students' interests; and by students' preferred ways of learning or expressing themselves. (Ravitch, 2007, p. 75)

Although there is limited research on the effects of differentiated instruction, most studies show a positive correlation with achievement and attitude (Rock, Gregg, Ellis, \& Gable, 2008). Fifteen high-poverty Title I schools in Prince George's County gained between 4.1 and 19 percentile points in reading and between 3.7 and 19.6 percentile points in math more than their non-poverty peers using a differentiated instruction based program. 
Supplemental services. Supplemental services can contribute to achievement in the low SES. Early screening of children, school based health centers, and food and nutrition programs contribute to healthier students.

Early screening. Early screening of children in which language delays, developmental delays, and health problems can be diagnosed and addressed is important. These delays can be diagnosed very early.

"Developmental screenings, which indicate whether a child is meeting expected developmental milestones or may have a developmental delay that requires further assessment, are part of a broader set of preventive health care practices recommended by experts, including the American Academy of Pediatrics (AAP)" (Johnson-Staub, 2014, p. $1)$.

In the Millennium Cohort study, the correlation between performance at nine months and five years was said to be significant even after the researchers considered the impact of poverty on children's development (Mansell, 2010). "This study of nearly 15,000 children said that babies who were slow to develop their motor skills at nine months were significantly more likely to be identified as behind in their cognitive development, and also likely to be less well behaved at age five" (Mansell, 2010, para. 2). The Nationwide Children's website (2015) reports that early interventions make a significant difference when treating children in the autism disorders spectrum. Using early screening can help children come to school more prepared to learn by providing early interventions. Studies have shown that children who receive early intervention and treatment for developmental disorders are more likely to graduate from high school, to hold 
jobs as adults, and are less likely to commit criminal acts than those who do not receive early intervention (Stoppler, 2014).

School based health centers and wraparound services. School based health centers can include dental, medical, and psychological services. Some also provide reproductive information to middle and high school students (Andrews, 2011). Wraparound schools offer these health services as well as summer and after school programs and parent training and involvement (Ravitch, 2013). In a Louisiana study by the Louisiana Public Health Institute, children with access to a school based health center had better general health, were physically more active, engaged in fewer risky behaviors, were less obese, made fewer visits to the emergency room, and were more likely to seek mental health help when needed (Louisiana Public Health Institute, 2010).

Food and nutrition programs. Food and nutrition programs for families include free breakfast and lunch programs, the Child and Adult Care Food Program, and nutrition programs for women who are pregnant. Research shows that eating breakfast contributes to improved student behavior and test scores, less absenteeism, and fewer trips to the principal's office. In a study of 5200 fifth-graders, those who ate more fruits and vegetables and who had high diet quality scores including fewer calories and less saturated fat were $41 \%$ "less likely to fail a standardized reading and writing test" (“Good Food”, 2008 , para. 1). "With one in four American children living in food insecure households, schools should ensure kids have access to a healthy breakfast every school day" (Ford, 2013, p.58).

Improving nutrition increases economic growth and reduces income poverty through three routes. Bigger and healthier bodies lead to higher physical productivity. Well- 
nourished children are more intelligent, better learners in school, and more productive as adults. And well-nourished populations spend less on health care, freeing resources for investment and growth. (World Bank, 2005, p. 1)

\section{Other influences on students' academic success, achievement, and well-being. Other}

influences that have affected student achievement include National Board Certification of teachers. National Board Certification for teachers is a peer- reviewed rigorous process based on performance standards (National Board for Professional Teaching Standards, 2014). Although there are conflicting studies of the impact of National Board Certified Teachers on student achievement, several studies have found strong evidence that National Board Certified teachers increase student achievement (Cavalluzzo, 2004; Smith, Gordon, Colby \& Wang, 2005; Vandervoort, Amrein-Beardsley \& Berliner, 2004).

\section{West Virginia Initiatives Proposed to Address the Low SES Achievement Gap}

In 2009-2010 the West Virginia Department of Education (WVDE) released the third edition of Closing the Achievement Gap Report for $21^{\text {st }}$ Century Learners in West Virginia by the department's Office of Assessment, Accountability, and Research, Division of Curriculum and Instructional Services. The report addressed the literature and research about factors that impact student performance, the status and progress of subgroups, and the programs and strategies being used to address the achievement gaps. It then offered educators, policy makers, parents, and the general public data and information about student performance in West Virginia and actions being taken by the West Virginia Department of Education to address these findings. Initiatives in this section were through the Department of Education although several rely on outside funding and volunteers ( $21^{\text {st }}$ CCLC programs and the Quality Enhancement for Language and 
Literacy Project (QELL).The report concluded that "In measuring/examining academic performance between Economically Disadvantaged (ED) and All students on standardized assessments either internationally, nationally, or by state, it is clear that persistent, often significant, achievement gaps still exist between ED and All students" (WVDE, 2009, p. 31). The following initiatives to address the low SES achievement gap were outlined in the 20092010 West Virginia Department of Education report Closing the Achievement Gap Report for $21^{\text {st }}$ Century Learners in West Virginia (WVDE, 2009).

Extended time. Extended time was addressed through recommending more money for after school programs through the $21^{\text {st }}$ Century Community Learning Centers $\left(21^{\text {st }} \mathrm{CCLC}\right)$. Recommendations also included providing universal pre-k access along with special education services and other initiatives that provide early services before students enter school.

$2 \mathbf{I}^{\text {st }} \boldsymbol{C C L C}$. Twenty-first Century Community Learning Centers are funded through the Elementary and Secondary Education Act based on poverty. They provide a minimum of 36 weeks of 12 hours of academic and enrichment activities before and after school and in the summer. Between 2004 and $201421^{\text {st }}$ CCLC sites have served 102,000 students in West Virginia. In 2014 the WVDE listed 24 centers in West Virginia (WVDE, 2014a)

Early childhood education. West Virginia passed legislation that required universal prekindergarten access in all 55 West Virginia counties by 2012-2013. Half of these programs had to collaborate with private prekindergarten, Head Start and/or child care facilities (WVDE, 2013).

The state continued Even Start (Title I, Part B) which provides early language and literacy training for families and adult and early childhood education. These projects require a 
partnership between a school and at least one community partner (WVDE, 2013. Research has indicated mixed results and federal funds are limited.

Public preschool special education. This is a requirement under IDEA. Eligible children with developmental delays are provided an Individualized Education Plan (IEP) and receive a variety of services. "In 2006-2007 6,033 eligible children, ages three through five years, received services" (WVDE, 2009, p. 187).

Classroom strategies. Strategies include class size limits, Response to Intervention (RTI), differentiated instruction (Support for Personalized Learning), and testing. Fitness is monitored through the Fitnessgram and the HEAP Project. High Schools for West Virginia's Future task force recommended strategies to keep students in school. The West Virginia Summative Assessment continues to be a way to monitor student achievement through standardized testing. It is accompanied by several formative assessments including DIBELS (Dynamic Indicators of Basic Early Literacy Skills).

Class size. Under WV Code §18-5-18a teacher-pupil ratio West Virginia maintains a class size limit for students. The limit is 20 for kindergarten and 25 for grades 1-6.

RTI. Response to Intervention (RTI) which is now called Support for Personalized Learning (SPL) is a process rather than a program and is used in West Virginia Title I schools in grades K-3. It offers three tiers of reading instruction from general delivery of content to intervention to intense intervention. It is based on universal screening, the use of research based programs and interventions, and constant monitoring of students (WVDE, 2009). In a 2010 study of 83 students " $68 / 83$ (or $81.92 \%$ ) of students were able to reach grade level benchmarks using 
intensive tier 2 interventions, as compared to $15 / 83$ (or 18.08\%) who did not reach the standard of proficient" (Maskill, 2012, p. 25).

Differentiated instruction. The Differentiated Skills Cadre trained teachers to use differentiated skills in their teaching.

Fitness. In 2006-2007 West Virginia administered the Fitnessgram which assessed aerobic capacity, body composition, and muscular strength and endurance. The Health Education Assessment Project (HEAP) assessed nutrition, physical activity, growth and development, and drug, alcohol, and tobacco use (WVDE, 2009).

Testing. Standardized testing through the West Virginia General Assessment which is administered each spring is a strategy to increase achievement. West Virginia teachers also use formative assessments such as Dynamic Indicators of Basic Early Literacy Skills (DIBELS) which is a quick assessment of early literacy skills and is used for evaluating individual student development and grade-level performance (WVDE, 2009).

High Schools that Work. The Closing the Achievement Gap Report for $21^{\text {st }}$ Century Learners in West Virginia included the establishment of 42 High Schools that Work which feature high expectations, guidance systems, and other key practices including academic support, career and technical support, and work based experiences (WVDE, 2009).

Supplemental services. All counties provide health services throughout the school day although not every school has a nurse. In 2006-2007, school-based health services offered over 33,000 students health care through nurses, medical providers, clinicians, dentists, dental hygienists, and counselors (WVDE, 2009). 
In West Virginia the West Virginia Feed to Achieve Act offers food and nutrition programs. "The West Virginia Feed to Achieve Act is a progressive piece of legislation and is the first of its kind in the nation. The need for the bill was simple: Every child needs nutritious meals in order to achieve his or her potential" (WVDE, 2016b, para. 1). The West Virginia Department of Education administers many nutrition programs through the United States Department of Agriculture: National School Lunch Program, Child and Adult Care Food Program, Summer Food Service Program, Community Eligibility Option, Fresh Fruit and Vegetables Program, School Breakfast Program and the Special Milk Program (WVDE, 2015a).

\section{Other influences on students' students' academic success, achievement, and well-} being. Other influences included West Virginia initiatives in teacher training and National Board certification.

Teacher training. Initiatives listed in the report include alternate routes to certification and support for National Board Certified teachers as well as professional development institutes, cadres, e-learning opportunities, and professional development schools (WVDE, 2009).

The Teacher Leadership Institute. The Institute was established by the West Virginia Department of Education to offer an intense leadership training summer session in standards and project based learning. Teacher and county administrative leaders are chosen to participate (WVDE, 2009).

The Comprehensive Plan for Increasing Student Achievement in Math and Science. County based math teams have evolved into Regional Education Service Agency based teams with the goal of providing professional development in math and science. The Mathematics Community Advisory Committee is another result of this initiative (WVDE, 2009). 
Differentiated Skills Cadre. The Middle School Differentiated Instruction Project included 20 special education teachers and 27 general education teachers who would then provide on-going training and professional development for teachers across the state (WVDE, 2009).

National Board certification. National Board Certification, a voluntary national certification that teachers can elect and states encourage, is designed to improve the quality of teachers and is offered by the National Board for Professional Teaching Standards. Teachers submit a portfolio that reflects their content knowledge, their thinking about student work, and an analysis of a video of their teaching that is then assessed according to its standards. Over 110,000 teachers have pursued this certification, and 860 teachers have this certification within West Virginia (National Board for Professional Teaching Standards, 2015).

National Board Certification is still encouraged and financially supported through the West Virginia Legislature and the Department of Education (WVDE, 2009). Those applying for the certification receive one-half of the registration fee when applying and one-half for completion. They are also eligible for $\$ 600$ in expenses. The state gives a $\$ 3500 /$ year supplement for ten years or the life of the certificate for those who are certified, and local counties may supplement.

\section{Policies and Initiatives}

Policies and initiatives that pertain to education must first be proposed and referred to the appropriate body for study, clarification, amendments, adjustments, and, finally, referral to the enacting body. Once these initiatives become rules, regulations, and laws, they are enacted. This 
implementation can be facilitated or impeded by the presence or absence of implementation factors that have been shown to improve that implementation (Fowler, 2009).

Policy generators. Generally, policies and initiatives are generated in several ways and from various groups including legislatures, state boards of education, state departments of education, higher education, local boards of education, professional groups, and parent groups (Fowler, 2009). While teacher professional groups do promote policies and initiatives generated by teachers who are active in the association, most teachers do not have input into initiatives that are suggested for their schools and classrooms. In West Virginia, policies and initiatives usually emanate from the State Department of Education and then through the West Virginia Board of Education.

Policy implementation. Implementation is the stage of policy development where the policy that has been adopted by a government agency is put into practice. The implementers have the legal authority to make sure the policy is put into effect (Fowler, 2009). If initiatives are to be successful, they must be implemented successfully in schools and classrooms. As Mary Kennedy (2005) observed, reformers often do not take into account the realities of classrooms. Kennedy also realized that the answers to why reforms, policies, and initiatives are not used, used unsuccessfully, or used and then abandoned lie within the classrooms and schools where they are being implemented.

\section{Policy Implementation in West Virginia}

In West Virginia, policies and rules are generated through the West Virginia Department of Education and the West Virginia Board of Education. Under, §18-2-5 of the West Virginia State Code, the West Virginia Board of Education has authority to generally supervise the free 
schools in the state. The Board must meet monthly. Their duties under $\S 3-29-\mathrm{A}$ in the West Virginia State Code include attendance, school classifications, and those general powers and duties necessary to perform these duties.

Under the West Virginia Constitution the West Virginia Legislature has the constitutional responsibility for guaranteeing a thorough and efficient school system, collecting and designating taxes, and passing school laws. The legislature receives bills that have been written for them or that have been introduced by a member of the legislature. The West Virginia legislature has been recognized as being one that is "largely unprofessionalized" (Fowler, 2009, p. 145) meaning that legislators are not full-time, are not highly paid, and do not have large staffs. That makes it even more important for them to receive information about proposed laws and initiatives from the education community.

Policy factors. Once a policy or initiative is put into place by law, regulation, or policy, teachers need to make sense of the policy and how it will work in their schools and classrooms. If not, the initiative, as aforementioned, may not be implemented correctly, may be used and then abandoned, or not implemented at all (Kennedy, 2005). "People responsible can never take for granted that those under them will put a policy into effect simply because they are supposed to..." (Fowler, 2009, p. 277).

Individual cognition; situational and content factors; tacit knowledge; and values and emotions are part of the process whereby teachers are able to understand and successfully implement initiatives (Spillane et al., 2002). "Implementation involves interpretation because implementers must figure out what a policy means and whether and how it applies to their school in order to decide whether and how to ignore, adapt, or adopt a policy locally" (Spillane et al., 
2002, p. 6). This is reflected in the survey through the policy implementation factors in which teachers rate their perceptions on whether an initiative is consistent with their beliefs and then with the school and classroom culture (Appendix A).

Spillane, Reiser, and Reimer (2002) looked at policy factors that will help to ensure successful implementation. Teachers need to make sense of the initiative and then be provided with the training, input, and resources needed to facilitate implementation. This may lead to better preparation, better implementation, and better results for the academic achievement of students in the low socioeconomic subset. Too often those who create or generate policies and initiatives do not have input from teachers. Policy implementation should involve all stakeholders, especially principals and teachers (Spillane, Reiser, \& Reimer, 2002).

\section{Chapter Summary}

National and state reforms and initiatives intended to address the achievement gap between low socioeconomic students and all students have not succeeded. This has been attributed to many reasons including poverty, insufficient and unfair funding of education, lack of proper implementation of initiatives, and emphasis on high stakes standardized testing. Due to federal and state reforms, accountability has increased significantly on the school and district fronts.

Factors affecting poor students' achievement include poverty and its effect on students and families: poor nutrition; mothers who do not receive prenatal care; dangerous and unhealthy neighborhoods; parents who do not have time, ability, or understanding of appropriate child rearing methods; and chronic and acute stress (Jensen, 2009). Some initiatives and reforms have shown to positively affect poor students' achievement. The following have been studied and 
show positive results: high quality extended learning opportunities; small class size; school curricula that include the arts, physical activity, and resilience training; and supplemental health and nutrition services. Testing appears to be more effective when used in a formative way. Charter schools and school vouchers have not been shown to help. Underlying the problem is the disparity between rich and poor schools in rich and poor areas and the unequal opportunities and resources in rich and poor neighborhoods where children live.

The West Virginia Department of Education issued a report in 2009 (WVDE, 2009) that listed initiatives for addressing the low socioeconomic gap. Those initiatives included in the study were under early education, classroom strategies, supplemental services, and other influences.

Policies and initiatives in West Virginia are the responsibility of the West Virginia Department of Education, the West Virginia Board of Education, and the West Virginia Legislature. Professional organizations, higher education, and other groups can lobby or present proposals for bills to the state board or the legislature. Teachers' main path to input into the system is through their professional organizations or faculty senates and school improvement council membership.

Successful implementation of policies and initiatives in the classrooms and schools is affected by factors such as teacher preparation, teachers' beliefs in the initiative, the ease of implementation, and adequate time and materials (Spillane, Reiser, \& Reimer, 2002). These factors have been incorporated into the survey. The 16 initiatives are from the literature review. The demographic variables are those that showed significant differences in a similar study with similar reforms in Georgia. 


\section{Chapter 3}

\section{Research Design}

\section{Introduction}

The West Virginia Department of Education recently reported that West Virginia students in the low SES group were 10 percentage points below all students in math proficiency and nine percentage points behind in reading proficiency (WVDE, 2015b). The achievement gap associated with the low socioeconomic group persists in West Virginia and across the United States (Reardon, 2011). Researchers, policy makers, and educators have studied and proposed initiatives. The 2009-2010 Closing the Achievement Gap Report for 21st Century Learners in West Virginia recommended initiatives to address the achievement gap as it pertains to the low SES children in West Virginia (WVDE, 2009). Teachers' perceptions of these and other proposed initiatives may give insight into the use of these reform initiatives in increasing achievement for poor children and reducing the achievement gap. The purpose of this study was to develop a valid and reliable instrument to measure teachers' use and perceptions of initiatives that address the low socioeconomic achievement in West Virginia Title I schools. Chapter 3 includes the following: introduction, purpose of the study, and research methodology. The research had two phases: Phase 1- survey development, and Phase 2-establishing validity and reliability. It ends with a chapter summary.

\section{Research Question}

The research question is: What are the psychometric properties (i.e., reliability and validity) of a survey instrument that is designed to assess teachers' perceptions of the uses and effectiveness of reform initiatives that have been implemented in high poverty schools to address the academic achievement of low-SES students in Title I schools? 
The need for teacher input was recognized by the United States Department of Education. The Teaching Ambassador Fellowship is designed to improve education for students by involving teachers in the development and implementation of national education policy:

Teachers perform many vital leadership activities in classrooms and schools, but too often lack opportunities to contribute their knowledge to the development of education policy on a broader scale. The U.S. Department of Education designed the Teaching Ambassador Fellowship to enable outstanding teachers to bring their classroom expertise to and expand their knowledge of the national dialogue about education. In turn, Teaching Ambassador Fellows facilitate the learning and input of other educators and community members. (United States Department of Education, 2016, para. 4)

These cohorts of teachers are on leave, part-time or full-time, from their classrooms and contribute to conversations and decisions about government policies. This recognition of the need for teacher input represents one of the reasons for this study (USDE, 2016).

\section{Research Methodology}

The research was conducted in two phases. The first was the development of a survey. The second phase was establishing its validity and reliability.

Phase 1: Survey development. Phase 1 consisted of the four components in the design of the study--identifying and describing the problem; the review of literature; identifying the specific target population and the method for collecting data; and instrument development (Labree, 2016).

Identify and describe the problem. There is a lack of teacher input into the evaluation of initiatives in Title I schools. A 2012-2013 U.S. Department of Education Teaching Ambassador 
Fellow Mike Humphreys commented on the importance of ongoing conversations with teachers about reforms.

Highly visible in this document-and certainly pushed to the front in many of the teacher roundtables in which I have been involved-is the importance of teacher voice in the ongoing conversation about reform. For too long the educators on the ground have lacked an effective way to directly inform and influence education policy and programs at the federal, state, and district level. Many of those serving in education offices may not have seen the inside of a classroom from a teacher's eye view, and it is important they understand our view as they develop and implement policies that affect us in the classroom. (Homeroom, 2012, n.p.)

In a study of 450 education reforms across 34 countries, the Organization for Economic Co-operation and Development (OECD) found that only one in ten education reforms had been analyzed for their impact. The report emphasized that teacher and parent input were critical elements in the success of reforms (Ware, 2015).

The OECD found that those reforms that had been implemented most successfully (even if they had not been evaluated for impact) were those where students and learning were placed at the centre and where teachers and parents were also engaged in the process. (Ware, 2015, Drivers of Reform, para 4)

Mary Kennedy also emphasized the importance of teacher input into reforms. Reforms often do not reflect the realities of the classroom, and/or the importance of teacher knowledge, teacher beliefs and values, and teacher dispositions (Kennedy, 2005). 
Review of the literature. A review of the literature in Chapter 2, revealed that the low socioeconomic achievement gap continues to be a problem across the United States (Reardon, 2011).

The reform initiatives section of Chapter 2 contained many initiatives recommended to improve the achievement of these low socioeconomic students: quality preschool; extended time; curricula that include the arts and physical education; differentiated instruction; Response to Intervention; resilience training; wrap around services that provide mental and physical health services; prenatal care for poor mothers; nutrition programs; standardized testing and tracking, both summative and formative; early screening of children; class size limits; National Board Certification; and high expectations by teachers.

West Virginia, in the 2009-2010 report Closing the Achievement Gap Report for $21^{\text {st }}$ Century Learners in West Virginia (WVDE, 2009) listed initiatives prescribed to address the low socioeconomic achievement gap. These initiatives included: extended time, universal preschool, classroom strategies, summative and formative assessments, and other supplemental services (WVDE, 2009).

In the section on Policy Implementation of Chapter 2, nine policy factors that influence implementation of initiatives are listed: training, materials, necessary time, teacher input into the design, teacher input into implementation, opportunities to collaborate, consistent with beliefs, easy to implement, and requiring no major changes (Fowler, 2009). Teachers need to make sense of new initiatives and be provided with training, materials, time, and input into their design and implementation so that these initiatives are implemented as planned (Fowler, 2009; Spillane et al., 2002). 
Teacher input is important in successful implementation of initiatives and also in evaluating the effect of initiatives in improving the academic achievement of poor children. As Kennedy and others have observed, teacher input into designing, implementing, and evaluating initiatives for the low socioeconomic children in their classrooms is important (Kennedy, 2005)

A 1990 study of teachers' perceptions of reforms in 64 schools in 40 county service areas of the Southern Teacher Education Center in southeastern Georgia was commissioned to look at how teachers perceived the teaching profession and various educational reforms and how background variables influenced their responses. Specifically, two of their research questions related to this study: "How do SEGA (Southeast Georgia) teachers perceive various proposals for educational reform?", and "Do SEGA teachers, categorized on the basis of background variables, differ in their perception of the teaching profession and educational reform?" (Page \& Page, 1990, p. 4). The four variables chosen from the Georgia study had shown significant differences in the initiatives being included in this survey: programmatic level, age, gender, and years of experience.

The literature points to initiatives that have not worked, as well as those that have had a positive impact on student achievement. Implementation factors may play an important role in why initiatives succeed or fail. Demographic variables of teachers may also influence this process. There is a lack of research about the perceptions of teachers who work with initiatives on a daily basis.

\section{Identify the specific target population and method of collecting data. The specific} target population for the survey will be teachers in West Virginia Title I schools, including Title I Specialists. These teachers teach in 342 West Virginia public schools that are designated as Title 
I schoolwide projects and two that are targeted assistance schools. Schoolwide projects are schools in which at least $40 \%$ of their students qualify as poor children under the Title I guidelines (WVDE, 2014b). Schools that do not have $40 \%$ or who choose not to have a schoolwide project are targeted assistance schools and “...must focus Title I services on children who are failing, or most at risk of failing, to meet state academic standards" (USDE, 2014, Program Description, para 3). These teachers can be surveyed about the use of reforms in their classrooms and whether they improve their students' achievement.

Instrument development. A survey instrument is appropriate for this study. No comprehensive instrument was found in the literature. Surveys are used in quantitative research to collect data that describe "one or more characteristics of a specific population" (Gay, Mills, \& Airasian, 2009, p. 175). "Survey research is one of the most important areas of measurement in applied social research. The broad area of survey research encompasses any measurement procedures that involve asking questions of respondents" (Web Center for Social Research Methods, 2006, para. 1).

The survey was designed to collect the following data: teacher demographics, use of initiatives in Title I schools, factors that affect policy implementation, and the perception of classroom teachers as to the impact of these initiatives on the academic achievement of students. The literature formed the basis of the development of the survey items including the initiatives, implementation factors, and the demographic indicators. There are two survey sectionsdemographics and initiatives. The survey can be found in Appendix B and the Policy Implementation factors are in Appendix A. 
A draft instrument was produced by the researcher. Approximately 20 initiatives were extracted from the literature. They were listed, defined in one sentence, and research findings were summarized in one sentence. Multiple drafts were edited by the researcher and Chair. A matrix of the items with the citations from research was developed (Appendix C). A Likert scale was then selected.

Likert scales are often used in surveys, also called questionnaires. This type of scale allows for a ranking of perceptions (Gay et al., 2009). Teachers are asked if they use the initiative in their Title I school and are directed to answer yes or no. If they answer yes, they are directed to a screen where they are asked for their perceptions on factors that affect the implementation of each of these initiatives. For example, "I have had the training that I need to implement this initiative," and "I have had the opportunity to collaborate with my colleagues." Choices range from Strongly Agree to Strongly Disagree with an added choice of Does Not Apply. They are also asked if the initiative has positively affected academic achievement with the same answer choices. There is a comment box after each initiative to allow for additional information.

Construction of the survey followed these guidelines: clear directions at the beginning and end; clearly worded items with defined terms, no ambiguity, and no leading questions; and the use of close-ended items (Gay et al., 2009),

Clear directions. The directions in the invitation to participant letter to teachers (Appendix D) identified the researcher, the purpose of the survey, the availability of accessing the results of the survey, and assurances of confidentiality. The following directions were used in the introduction to the survey. 
This is a request for you to take part in a pilot test of a survey instrument that is being proposed to measure teachers' use and perceptions of policies and initiatives recommended to improve the academic achievement of the low socioeconomic children in West Virginia Title I schools and classrooms. All of these policies and initiatives have a base in researched studies.

Part 1: Demographics directions: Please answer the demographic questions. You may leave items blank.

Part 2: Initiatives Directions:

In this section, you will be asked if you use a particular initiative. If you answer yes, you will be asked to rate a series of policy factors as either strongly agree (4), agree (3), disagree (2), or strongly disagree (1). If this factor does not apply or if you are not sure, you may choose does not apply (0). You will be asked whether you have had training, materials, etc. Some factors will not apply to the particular initiative or policy, so you can mark does not apply.

Wording. Studies have shown that changing even one word can affect survey responses. Wording should be clear, direct, absent of jargon or confusing terms, and refer to familiar items and information. Definitions should be consistent. In the survey a definition and relevant research is provided for each initiative. Negative and double negative questions should be avoided. Items should be succinct and to the point (Larossi, 2006). Leading questions should not be used as they tend to push respondents in a certain direction through their content, structure, or wording. They imply or suggest a certain response (Warwick \& Lininger, 1975).

Each of the sixteen initiatives was listed with a research component. Example: 
Universal Preschool. Universal preschool is one strategy that has been used to give poor children the ability to enter first grade with the skills and language ability of their more affluent peers. Quality preschool programs can have positive effects on high school graduation, achievement scores, future employment, and economic security and can reduce delinquency rates and special education placements (Frank Porter Graham Child Development Institute, 2014; Schweinhart, 2005).

Close-ended items. Close-ended items are also called structured items. Respondents must choose from a set of items that have been provided. Surveys with structured items are easier and quicker to tabulate and provide the information needed (Gay et al., 2009). For example in the survey, respondents are asked their years of experience in categories rather than an open-ended format.

Phase 2: Establishing validity and reliability. Phase 2 established the validity and the reliability of the instrument. This was done through a panel of experts, a survey at a West Virginia Title I school, and cognitive interviewing.

Survey validity. Validity is the degree to which a survey measures what it is purported to measure. "Validity is specific to the interpretation being made and to the group being tested" (Gay et al., 2009, p. 154). There are several forms of validity. Content validity is the "degree to which a test measures an intended content area" (Gay et al., 2009, p. 155).It cannot be determined through quantitative means so experts in the field are asked to review the survey questions and to make a determination as to whether the items included in the survey represent the intended content (Gay et al., 2009). Validity measures the degree to which a survey measures what it is purported to measure. "Validity is specific to the interpretation being made and to the 
group being tested" (Gay et al., 2009, p. 154). Are the survey questions asking valid questions? Does the survey reflect what it is supposed to measure? Content validity cannot be determined through quantitative means so experts in the field are asked to review the survey questions and to determine whether the items included in the survey represent the intended content (Gay et al., 2009). Validity of the instrument was assessed through a review of the survey instrument by a panel of experts.

The survey was assessed by a panel of experts. Criteria for selection of panel members included: experience and/or familiarity with: at-risk and Title I children, reform initiatives to address the achievement gap of low-performing children, and survey development. This diverse group of educators includes a West Virginia superintendent, an expert in survey methods, a Director of Title I for the West Virginia Department of Education, who has wide experience as a principal, superintendent, and a former principal and superintendent working with at-risk children.

A letter of invitation was sent by email to the panel members (Appendix E). They were asked to evaluate the survey (Appendix F). Information linking each listed initiative to the research was provided (Appendix C). The researcher then reviewed the panel recommendations and made changes to the survey. Results are reported in Chapter 4 and in Appendix G.

Survey reliability. Reliability is basically "the degree to which a test consistently measures whatever it is measuring" (Gay et al., 2009, p. 141). Reliability was determined through a survey of 26 teachers who were representative of the larger group for whom the survey was designed (Gay et al., 2009). The survey was conducted online with these teachers in a West Virginia Title I school over a period of one week with a reminder after three days. The 
superintendent (Appendix H) and the principal of the school (Appendix I) were first notified. All survey respondents were entered into a drawing for a $\$ 50$ gift card.

Cronbach's Alpha was used to establish reliability. This statistical test measures internal consistency or expected correlation of two measures or tests of the same constructs. Tests results using the same constructs should be consistent when repeatedly administered.

The average correlation of a set of items is an accurate estimate of the average correlation of all items that pertain to a certain construct. A split-half reliability process was used in which each participant has two scores for the survey, one for the first half and one for the second (Rahadkrishna, 2007). The first half should correlate with the second half. The formula for Cronbach's Alpha is $\quad \alpha=\frac{N \cdot \bar{C}}{\bar{v}+(N-1) \cdot \bar{C}} \quad$ with $a$-Cronbach's Alpha; $N$-number of responses; c-bar is the average inter-item covariance among the items and v-bar equals the average variance. If the average inter-item correlation is low, alpha will be low; if it is above .70 it is considered to be reliable (Institute for Digital Research and Education, 2015).

Cognitive interviews. After the survey was administered to 26 teachers in a West Virginia Title I elementary school, a cognitive interview was conducted with four of the teachers. The superintendent and the principal were notified that cognitive interviews would be held with four teachers who volunteered from the West Virginia Title I school where the survey was being distributed. An invitation to participate in the cognitive interviews with a return email address was included in the Teacher Invitation for Pilot Survey sent to all teachers at the West Virginia Title I school where the survey was conducted. The invitation was sent electronically through 
their emails. (Appendix D) Four teachers volunteered. Volunteers were given a $\$ 20$ gift in appreciation for their time.

Cognitive interviewing is typically conducted with a small, manageable number of participants, usually three or four people who are representative of the population (Gay et al., 2009). Cognitive interviewing is an effective means of pretesting surveys. Respondents are encouraged to think aloud about the survey questions (Dillman \& Redline, 2004).

The cognitive interviews involved observation of the four teachers taking the survey to determine if they understood the questions and the answer choices as intended by the researcher (Collins, 2003). The observation used a scripted retrospective method and a think aloud method. These two methods are often combined (Collins, 2003). The think aloud method is more respondent driven while the retrospective method is more interviewer driven. The think aloud method allows the respondents to ask questions as they occur while taking the survey. The retrospective scripted interview allows the researcher to gather information on topics that have been chosen by asking scripted questions when teachers have finished the surveys. Scripted questions allow the researcher to find out about specific aspects of the survey (Haeger, Lambert, Kinzie, \& Gieser, 2012).

Considerations that are important when developing a survey instrument include: comprehension of the questions; ability to make a response given the information; ability of the respondent to find an appropriate answer choice and the ability to answer the question without influence from the way the questions or answers are constructed (Collins, 2003; Daugherty, Harris-Kojetin, Squire, \& Jael, 2001; Jobe, 2003; Willis, 1999, 2005). The following prompts were used during the cognitive interview as part of the retrospective interviewing process: 
a. Are the questions clear and understandable? (Comprehension of the questions)

b. Did you understand the response options? (Ability of respondent to find an appropriate answer choice)

c. Are the answer formats appropriate? (Scales used and wording of choices)

d. Are the response choices relevant to the questions? (Do the response choices allow you to choose relevant unbiased answers to the questions?)

\section{Chapter Summary}

In Chapter Three there were two phases. In Phase 1 the instrument was developed. Phase 1 consisted of the four components in the design of the study--identifying and describing the problem; the review of literature; identifying the specific target population and method for collecting data; and instrument development. In Phase 2 validity and reliability are planned for the instrument. In Phase 2 validity can be established through a panel of experts. Reliability for each initiative and all factors can be established through a survey study with a split-half reliability test using Cronbach's Alpha and cognitive interviewing. 


\section{Chapter 4}

\section{Instrument Validity and Reliability}

The purpose of the study was to develop a valid and reliable tool that will measure teachers' use and perceptions of national and West Virginia initiatives directed at the achievement gap for the low socioeconomic subset in West Virginia Title I schools. The research question was: What are the psychometric properties of a survey instrument that is designed to assess teachers' perceptions of the uses and effectiveness of reform initiatives that have been implemented in high poverty schools to address the academic achievement of low-SES students in Title I schools?

\section{Validity Results}

There are four forms of validity: content, criterion, construct, and consequential. Criterion validity relates performances on one test or survey to another; however, this is an original survey so there was no comparison possible. Construct validity measures "the degree to which a test measures an intended hypothetical construct" (Gay et al., 2009, p. 157). Consequential validity measures the harmful effects that the test or instrument on the user. Neither of these forms of validity were needed. Content validity measures the degree to which a survey measures what it is purported to measure. Validity of a survey cannot be determined through quantitative methods so a panel of experts was asked to evaluate the survey (Gay et al., 2009). Four panelists were asked to evaluate the instrument. The panel of experts was asked to carefully review the process by which the survey was developed by reading the literature review and the research for each item. Then they were asked to make a judgment as to whether the test items were relevant to the content area 
The recommendations by the Panel of Experts are in Appendix H. Panelists agreed to keep all 16 reform initiatives. Modifications were made in a title, wording, grammar, and additional research for consistency. Panelists made no changes to the policy factors. Telephone calls were made to panelists when necessary to clarify recommendations. Two panelists who had asked for changes that required additional research or a more in-depth explanation were sent copies of the instrument with changes for a second review. All panel comments appear in Appendix $\mathrm{G}$ with different panelists identified by a different number if more than one panelist commented on an item. All modifications and researcher comments that were made in reply are in bold. In some cases revisions were not made, but an explanation as to why was included.

Changes were made to demographics by the panel and by the dissertation committee. The committee added county to determine location of initiative. Two additional demographic variables were suggested in a conversation with the panelists although they did not include them in their written comments. One was the addition of National Board Certification through NBPTS and one was the addition of highest education degree attained.

\section{Reliability Results}

A survey of 26 teachers in a West Virginia elementary Title I school was used to establish reliability of the survey. Reliability is "the degree to which a test consistently measures whatever it is measuring" (Gay et al., 2009, p. 141). Each factor was tested for each reform initiative. Individuals who were chosen to participate in the pilot survey should be similar to those for whom the survey is intended (Gay et al., 2009). Reliability was determined through a survey of the 26 teachers who were of the same type of population as the larger target population; in this case, West Virginia teachers in Title I schools (Gay et al., 2009). Sixteen 
teachers returned the survey electronically over a one week time period. Ten surveys were necessary to establish reliability. Isaac and Michael (1995) suggested that "samples with N's between 10 and 30 have many practical advantages" (p. 101), including simplicity, easy calculation, and the ability to test hypotheses, yet "overlook weak treatment effects." For similar reasons, Hill (1998) suggested 10 to 30 participants for pilots in survey research.

\section{Survey Results}

Cronbach's Alpha measures consistency or expected correlation of two measures or tests of the same constructs. Tests results using the same constructs should be consistent when repeatedly administered. Instead of administering the test several times, a split-half reliability process was used in which each participant had two scores for the survey, one for the first half and one for the second (Gay et al., 2009). The first half should correlate with the second half to establish reliability. "Internal consistency results when all the items or tasks on a test are related, or in other words are measuring the same things" (Gay et al., 2009, p. 161).

Table 1 lists the reliability coefficients of the 16 reform initiatives by their strength in descending order from strongest to weakest as established through Cronbach's Alpha. 
Table 1

Reliability Coefficients of Reform Initiatives

Reform Initiative

Reliability Coefficient

Arts Education

.994

Early Screening

.977

Teaching Resilience and Coping Skills

.973

School Based Health Centers and Wraparound Services

.963

Food and Nutrition Programs

.958

Response to Intervention

.946

Differentiated Instruction

.937

Increased Time in Physical Activity

.935

High Stakes Summative Testing

.935

Universal Preschool

.929

Adding Minutes/Hours/Days to School Calendar

.921

Formative Assessment

.905

Teachers' High Expectations

.904

National Board Certified Teachers

.898

After School Programs

.758

21st Century Community Learning Centers

.749

Cronbach's alpha reliability coefficient normally ranges between 0 and 1 . However, there is actually no lower limit to the coefficient. The closer Cronbach's alpha coefficient is to 1.0 the greater the internal consistency of the items in the scale. George and Mallery (2003) provide the following guides: “__ $>90-$ Excellent, ${ }_{-}>.80-$ Good, ${ }_{-}>.70-$ Acceptable, ${ }_{-}>.60-$ Questionable,_> .50 - Poor, and _ $<.50-$ Unacceptable.” A reliability coefficient of .70 is considered to be acceptable. 
All of the 16 reform initiative coefficients in the study were above .70 with 13 coefficients above .90 which means all 16 initiatives are acceptable. Arts education had the greatest reliability. The item 21st Century Community Learning Centers had the lowest reliability coefficient, although since the coefficient was above .70, it is considered to be acceptable. Of the 16 reform initiatives, 13 had a Cronbach's coefficient above .90 , which were considered excellent. One reform initiative had a coefficient at .898 , considered to be good, and two reform initiatives had coefficients at .758 and .749 , considered to be acceptable. All of the coefficients indicated acceptable reliability.

Cognitive interview results. Cognitive interviews are a good way to pretest a survey and discover any flaws or confusion about the questions, answers, or formatting (Collins, 2003). It is meant to "identify and analyze sources of response error in survey questionnaires by focusing on the cognitive processes respondents use to answer questions on a survey or questionnaire" (Haeger et al., 2012, p. 3). Soomro (2015) used cognitive interviewing because, “...it allows evaluating the survey in a way respondents naturally read the questionnaire" (p.65). The superintendent and the principal were notified that cognitive interviews would be held with four teachers who volunteered from the West Virginia Title I school where the survey was being distributed. An invitation to participate in the cognitive interviews with a return email address was included in the Teacher Invitation for Pilot Survey sent to all teachers at the West Virginia Title I school where the survey was conducted. The invitation was sent electronically through their emails. (Appendix D) Four teachers volunteered. Volunteers were given a \$20 gift in appreciation for their time.

The cognitive interviews took place with four volunteer teachers on two different days before and after school in a teacher's classroom. The teachers used their laptops or tablets to 
complete the survey. One teacher had difficulty accessing the survey and was given a paper copy. The interviews were tape recorded with the teachers' permission to provide accuracy in reporting. The recordings did not include the names or positions of the teachers. Two of the teachers had fewer than 10 years' experience and two teachers had more than ten years' experience. One teacher was nationally certified through the NBPTS and was a Title I Specialist.

It was observed that two teachers with more than 10 years of experience took approximately five minutes longer to take the survey than younger teachers with less than ten years of experience. Average time to take the survey was 15 minutes.

The four teachers who volunteered were interviewed using both the think aloud method and the retrospective scripted method so that teachers could also ask questions or make comments as they took the survey. In the think aloud method, teachers may ask questions or make comments while taking the survey. In the scripted retrospective method the researcher asks a set of predetermined questions which are asked of each respondent at the completion of the survey. The two methods are often combined (Collins, 2003).

Think aloud. During the think aloud part of the interview teachers took the survey and asked questions or made comments. Teachers asked the following questions during the think aloud time. For the reform initiative, Adding Minutes/Days/Hours to the Calendar, one teacher asked if this meant Title I Summer School. The researcher asked her what she thought. The teacher replied that yes, it did. For the reform initiative, Increased Time in Physical Activity, the teacher thought aloud about whether that meant in her classroom or school and then concluded that she did physical activity in the room and it was offered in the school. 
One teacher did not understand the National Board Certified Teacher question and asked if there was a certified board teacher in the building. One of the teachers taking the survey was nationally certified and the teacher who had asked said, "Oh, yes, I forgot." Another teacher asked a question about Pre-K. So, I don't teach Pre-K. Do I still check it? The researcher asked if it took place in the school and that school and classroom use both counted as use.

Teachers' questions about ambiguity were usually answered by the researcher with "What do you think the question is asking? Tell me what you are think." This type of combined use of think aloud questioning is acceptable (Collins, 2003). All teachers with questions did interpret the questions as the researcher had intended. One complaint was voiced by a teacher who said that she could not go back and change an answer once she had thought about it.

This feedback suggested to the researcher to customize question stems based on whether the reform initiative was likely to be in a school or in a classroom (Appendix K).

Retrospective scripted method. In a retrospective scripted interview the researcher asked a set of predetermined questions. Each teacher's answers were recorded separately. Table 2 presents the results of the retrospective interview questions given to the four volunteer teachers. 
Table 2

Results of Cognitive Interview Questions

Question

Yes No Not Sure Comments

Q1 Are the questions clear and easy to understand?

$4 \quad 0 \quad 0 \quad$ Yes

If not, how could they be made clearer?

Q2 Did you understand the response options-

$4 \quad 0 \quad 0 \quad$ Yes

the demographics and initiatives?

Q3 Are the answer formats appropriate for the

$4 \quad 0 \quad 0$

demographics, factors, and initiatives?

Scales? Wording? Answer choices and scales?

Q4 Were the response choices relevant and

$4 \quad 0 \quad 0$

were you able to make unbiased choices?

Q5 Is the time necessary to take the survey too long? $\quad \begin{array}{llll}3 & 0\end{array}$

$\begin{array}{llllll}\text { Q6 Did the incentive offered make you more } & 2 & 2 & 0 & \text { Yes }\end{array}$ willing to participate in the survey interview?

Q7 Did the research component under each initiative help? $4 \quad 0 \quad 0 \quad$ Yes

Q8 Were any of the initiatives not relevant and $\quad \begin{array}{llllll}0 & 4 & 0 & \text { Yes }\end{array}$ should be dropped? Would you suggest adding anything?

Note. Teachers' comments follow in text.

The teachers who took the survey through the cognitive interview process reported that the initiatives chosen were relevant and that all should be kept (Question 6.) Three of the four teachers thought the time to take the survey was appropriate (Question 5). The maximum time observed was 20 minutes with the average time being fifteen minutes. The researcher observed 
no inconsistencies and there were no unexpected questions (Suskie, 1996). Individuals' comments for questions were:

Q1. One teacher said that every question had the same answers and although she" could not think of a different way to do that", it was a concern for her.

Q2. One teacher remarked that she would not want more choices and liked having the “does not apply" option.

Q6. One teacher was unaware that there was an incentive and did the survey, "as long as it helps." One teacher did the survey to, "help the researcher in the study."

Q7. Yes, it definitely explained what you wanted." "Yes, it is helpful if you are not familiar." "It helped on some questions I did not understand at first."

Q8. "If you are a good teacher, you are using them anyway." "I think everything you asked should be in the school."

\section{Related Findings}

One survey question was analyzed in more depth because of its results. Teachers were asked, "Has this initiative improved the academic achievement of your students?" Although this was a survey of one school, an analysis of the means showed some interesting information about how teachers perceived the effect of reform initiatives on academic achievement. Means in this study are based on a scale of 1-4 with 1 being strongly disagree with the statement; 2 being disagree with the statement, 3 , being agree with the statement, and 4 being strongly agree with the statement. Questions and statements are designed to reflect positive perceptions of factors, so 3.0-4.0 shows general agreement or strong agreement that the reform initiative improved 
academic achievement. Table 3 lists the means of each reform initiative on whether teachers perceived it improved academic achievement. The higher the mean was, the greater the perception that the reform initiative did improve academic achievement. Standard deviations are also included. Variance shows the range and standard deviation shows the amount of variance. 
Table 3

Improved Academic Achievement Means

\begin{tabular}{llll}
\hline Reform Initiative & Mean on 4 point scale & Variance & S.D. \\
\hline 21st Century Community Learning Center & 3.88 & 0.13 & 0.35 \\
Teachers' High Expectations & 3.88 & 0.13 & 0.35 \\
After School Programs & 3.81 & 0.16 & 0.40 \\
Teaching Resilience and Coping Skills & 3.80 & 0.18 & 0.42 \\
Differentiated Instruction & 3.80 & 0.17 & 0.41 \\
Response to Intervention & 3.79 & 0.18 & 0.43 \\
Adding Minutes/Hours/Days to School Calendar & 3.72 & 0.21 & 0.47 \\
School Based Health Centers and Wraparound Services & 3.60 & 0.27 & 0.52 \\
Formative Assessment & 3.58 & 0.81 & 0.90 \\
Early Screening & 3.50 & 0.57 & 0.76 \\
Universal Preschool & 3.50 & 0.27 & 0.51 \\
Arts Education & 3.40 & 0.27 & 0.52 \\
National Board Certified Teachers & 3.33 & 1.47 & 1.21 \\
Increased Time in Physical Activity & 3.17 & 0.88 & 0.94 \\
Food and Nutrition & 3.09 & 1.30 & 1.70 \\
High Stakes Summative Testing & & 1.30 & 1.14 \\
\hline
\end{tabular}

Each reform initiative is examined for the mean on academic achievement which was strongly agree, 4; agree, 3; disagree, 2; and strongly disagree, 1.

The academic achievement question had 15 out of 16 means all above 3.0. High Stakes Standardized Testing was the only reform initiative under 3.0 with a 1.69 mean. This may 
indicate a perception by teachers in this survey that these reform initiatives, with the exception of high stakes summative testing have increased academic achievement. The highest means were $21^{\text {st }}$ Century Community Learning Centers at 3.88, Teachers' High Expectations at 3.88, Afterschool Programs at 3.81, Teaching Resilience and Coping Skills at 3.80, Differentiated Instruction at 3.80 and Response to Intervention at 3.79. The two reform initiatives with the lowest means were High Stakes Summative Testing at 1.93 and Food and Nutrition programs at 3.09. Standard deviations are also included and show how spread out the scores are. Those reform initiatives with the most spread were Food and Nutrition with a standard deviation of 1.70, National Board Certified Teachers with a standard deviation of 1.21, and High Stakes Summative testing with a standard deviation of 1.14 .

A second finding is related to policy implementation factors. Tables 4 and 5 list the nine policy implementation questions as they appear in the display logic series in the survey. In the survey teachers indicated whether they used an initiative such as Universal Preschool. If they answered yes, a logic menu then asked them nine policy implementation questions beginning with I have had the training that I need to implement this initiative. The statement factors are listed in Appendix A. The implementation factors were: necessary training; necessary materials; necessary time; design input; input into implementation; collaboration opportunities; consistent with beliefs; easy to implement; and no major changes. 
Table 4

Means and Standard Deviations (SD) for Each Reform Initiative and by 5 Implementation Factors

\begin{tabular}{|c|c|c|c|c|c|c|c|c|c|c|}
\hline & \multicolumn{2}{|c|}{ Necessary Training } & \multicolumn{2}{|c|}{ Necessary Materials } & \multicolumn{2}{|c|}{ Necessary Time } & \multicolumn{2}{|c|}{ Input into Design } & \multicolumn{2}{|c|}{$\begin{array}{l}\text { Input into } \\
\text { Implementation }\end{array}$} \\
\hline & Mean & SD & Mean & SD & Mean & SD & Mean & SD & Mean & SD \\
\hline Universal Preschool & 3.20 & 0.97 & 3.00 & 1.00 & 3.38 & 0.74 & 3.50 & 0.67 & 3.63 & 0.74 \\
\hline Afterschool programs & 3.77 & 0.44 & 3.50 & 0.52 & 3.50 & 0.65 & 3.50 & 0.63 & 3.60 & 0.63 \\
\hline 21st CCLC & 3.86 & 0.38 & 3.71 & 0.49 & 3.57 & 0.53 & 3.63 & 0.52 & 3.63 & 0.52 \\
\hline Adding Minutes/Hours/Days & 3.60 & 0.50 & 3.40 & 0.73 & 3.11 & 0.93 & 2.81 & 0.98 & 3.00 & 1.00 \\
\hline Teachers' High Expectations & 3.60 & 0.51 & 3.57 & 0.51 & 3.43 & 0.51 & 3.67 & 0.49 & 3.47 & 0.64 \\
\hline $\begin{array}{l}\text { Teaching Resilience and } \\
\text { Coping Skills }\end{array}$ & 3.36 & 0.67 & 3.09 & 0.70 & 3.27 & 0.79 & 3.40 & 0.73 & 3.40 & 0.73 \\
\hline $\begin{array}{l}\text { Increased Time in } \\
\text { Physical Activities }\end{array}$ & 3.18 & 1.08 & 3.45 & 0.69 & 3.09 & 0.83 & 3.09 & 0.83 & 3.18 & 0.87 \\
\hline Arts Education & 3.33 & 0.87 & 3.00 & 0.87 & 3.33 & 0.71 & 3.22 & 0.83 & 3.20 & 0.73 \\
\hline High Stakes Summative Tests & 3.31 & 1.03 & 3.38 & 0.96 & 3.15 & 0.99 & 2.07 & 1.12 & 2.00 & 1.18 \\
\hline Formative Assessment & 3.50 & 0.67 & 3.50 & 0.71 & 3.30 & 0.82 & 3.10 & 1.20 & 3.30 & 0.95 \\
\hline Response to Intervention & 3.53 & 0.52 & 3.53 & 0.52 & 3.62 & 0.65 & 3.53 & 0.78 & 3.53 & 0.78 \\
\hline
\end{tabular}




\begin{tabular}{|c|c|c|c|c|c|c|c|c|c|c|}
\hline & \multicolumn{2}{|c|}{ Necessary Training } & \multicolumn{2}{|c|}{ Necessary Materials } & \multicolumn{2}{|c|}{ Necessary Time } & \multicolumn{2}{|c|}{ Input into Design } & \multicolumn{2}{|c|}{$\begin{array}{l}\text { Input into } \\
\text { Implementation }\end{array}$} \\
\hline & Mean & SD & Mean & SD & Mean & SD & Mean & SD & Mean & SD \\
\hline Differentiated Instruction & 3.53 & 0.52 & 3.47 & 0.64 & 3.33 & 0.82 & 3.60 & 0.51 & 3.60 & 0.51 \\
\hline Early Screening & 3.33 & 1.21 & 2.30 & 1.40 & 3.17 & 1.17 & 3.17 & 1.17 & 3.60 & 0.55 \\
\hline School Based Health Canters & 3.00 & 0.76 & 3.00 & 0.76 & 2.88 & 0.83 & 2.78 & 0.97 & 2.67 & 1.00 \\
\hline Food and Nutrition & 3.20 & 0.79 & 3.40 & 0.73 & 3.10 & 0.78 & 2.78 & 1.20 & 2.75 & 1.28 \\
\hline NBCT & 3.25 & 0.96 & 3.50 & 0.58 & 2.80 & 1.30 & 3.40 & 0.89 & 3.25 & 0.96 \\
\hline
\end{tabular}


Table 5

Means and Standard Deviations (SD) for Each Reform Initiative and by 4 Implementation Factors

\begin{tabular}{|c|c|c|c|c|c|c|c|c|}
\hline & \multicolumn{2}{|c|}{$\begin{array}{l}\text { Opportunity to } \\
\text { Collaborate }\end{array}$} & \multicolumn{2}{|l|}{$\begin{array}{r}\text { Consistent with } \\
\text { Beliefs }\end{array}$} & \multicolumn{2}{|c|}{ Easy to Implement } & \multicolumn{2}{|c|}{ Requires no Major Changes } \\
\hline & Mean & SD & Mean & SD & Mean & SD & Mean & SD \\
\hline Universal Preschool & 3.60 & 0.70 & 3.86 & 0.13 & 3.63 & 0.50 & 3.09 & 0.94 \\
\hline Afterschool programs & 3.63 & 0.50 & 3.63 & 0.62 & 3.13 & 0.96 & 3.75 & 0.45 \\
\hline 21st CCLC & 3.75 & 0.46 & 4.00 & 0.00 & 3.43 & 0.79 & 3.50 & 0.76 \\
\hline Adding Minutes/Hours/Days & 3.27 & 0.65 & 3.63 & 0.50 & 3.09 & 0.94 & 3.18 & 0.60 \\
\hline Teachers' High Expectations & 3.40 & 0.74 & 3.73 & 0.46 & 3.38 & 0.81 & 3.75 & 0.45 \\
\hline Teaching Resilience and Coping Skills & 3.45 & 0.69 & 3.45 & 0.69 & 3.50 & 0.71 & 3.40 & 0.70 \\
\hline Increased Time in Physical Activities & 3.18 & 0.87 & 3.33 & 0.98 & 3.25 & 0.97 & 3.25 & 0.75 \\
\hline Arts Education & 3.40 & 0.73 & 3.38 & 0.74 & 3.44 & 0.53 & 3.44 & 0.53 \\
\hline High Stakes Summative Tests & 3.00 & 1.03 & 2.07 & 1.14 & 2.21 & 1.12 & 2.47 & 1.30 \\
\hline Formative Assessment & 3.50 & 0.53 & 3.33 & 0.89 & 3.00 & 1.10 & 3.08 & 1.08 \\
\hline Response to Intervention & 3.77 & 0.44 & 3.57 & 0.51 & 2.92 & 1.12 & 3.54 & 0.66 \\
\hline Differentiated Instruction & 3.53 & 0.52 & 3.73 & 0.46 & 2.87 & 1.06 & 3.27 & 0.70 \\
\hline Early Screening & 3.43 & 0.79 & 3.38 & 1.06 & 3.13 & 1.13 & 3.25 & 0.89 \\
\hline
\end{tabular}




\begin{tabular}{|c|c|c|c|c|c|c|c|c|}
\hline & \multicolumn{2}{|c|}{$\begin{array}{l}\text { Opportunity to } \\
\text { Collaborate }\end{array}$} & \multicolumn{2}{|c|}{$\begin{array}{l}\text { Consistent with } \\
\text { Beliefs }\end{array}$} & \multicolumn{2}{|c|}{ Easy to Implement } & \multicolumn{2}{|c|}{ Requires no Major Changes } \\
\hline & Mean & SD & Mean & SD & Mean & SD & Mean & SD \\
\hline School Based Health Canters & 2.89 & 0.93 & 3.36 & 0.92 & 3.00 & 0.94 & 3.10 & 0.99 \\
\hline Food and Nutrition & 2.90 & 0.99 & 3.27 & 0.90 & 3.18 & 0.98 & 3.00 & 0.89 \\
\hline NBCT & 3.17 & 1.17 & 3.33 & 1.21 & 2.67 & 1.51 & 3.80 & 0.20 \\
\hline
\end{tabular}


Means in this table are based on a scale of 1-4 with 1 being strongly disagree with the statement; 2 being disagree with the statement, 3 being agree with the statement, and 4 being strongly agree with the statement. Survey statements about the 9 policy implementation factors were designed to reflect positive perceptions of factors, so 3.0-4.0 shows agreement to strong agreement of a perceived perception that the implementation factor was present. All zero responses were discarded. The reform initiatives are listed in the order they appear in the survey Teachers rated their agreement with this statement on the Likert scale from 4 strongly agree to 1strongly disagree as described above. With each one of the 16 reform initiatives in the survey, teachers are asked if they use a reform initiative and, if they do, they are presented with the same nine policy implementation factors.

Eight reform initiatives had means at or above 3.0 for all 9 implementation factors. These reform initiatives had at least one implementation factor mean below 3.0: Adding Minutes/Hours/Days, High Stakes Summative Testing, Response to Intervention, Differentiated Instruction, Early Screening, School Based Health Centers, Food and Nutrition, and National Board Certified Teachers. The reform initiatives 21st Century Community Learning Centers and After School Programs had eight of the nine implementation factors means above 3.50. Increased Time in Physical Activity; Arts Education; High Stakes Summative Testing; School Based Health Centers and Wraparound Services;, and Food and Nutrition had no implementation factors with means at or above 3.5

The implementation factor, Training, had means above 3.0 for all reform initiatives. The implementation factors with the most means below 3.0 for reform initiatives were: Input into Design with means lower than 3.0 for Adding Minutes/Hours/Days/Time to School Calendar, High Stakes Summative Testing, School Based Health Centers and Wraparound Services, and 
Food And Nutrition; Easy to Implement with means lower than 3.0 for High Stakes Summative Testing, Response to Intervention, Differentiated Instruction, and National Board Certified Teachers; and Input into Implementation with means lower than 3.0 for High Stakes Summative Testing, School Based Health Centers and Wraparound Services, and Food and Nutrition.

\section{Chapter Summary}

The survey instrument was evaluated for validity through a panel of experts. All modifications were addressed. A survey was conducted with 26 teachers who were invited to take the survey online at a West Virginia Title I school. Reliability for each reform initiative was assessed through a split-half reliability test using Cronbach's Alpha. Results showed satisfactory and higher reliability coefficients for all reform initiatives.

In order to check that the survey was understandable and easy to take and that there were no unexpected problems, a cognitive interview session was held with four teachers who volunteered to take the survey with the researcher. Although there were some questions, the teachers interpreted them as the researcher had intended. Teachers were familiar with all of the reform initiatives and liked the addition of the research included for each item. They felt that the initiatives included were those that they used or thought should be used to help the academic achievement of their Title I students.

One teacher recommended they be allowed to go back to any question on the survey. Other teachers suggested a change in the stem question to "This initiative is used in my classroom, school, or school/classroom as most appropriate. 


\section{Chapter 5}

\section{Findings and Recommendations}

It is unusual today to read an educational journal or attend an education conference that does not include information about achievement gaps in this country. Research affirms that poverty is one major factor in the low achievement of poor children (Barton \& Coley, 2003; Evans, 2004; Jensen, 2009). In West Virginia, with one quarter of children living in poverty, the achievement gap between low socioeconomic children and regular students in the state merits attention. Experts agree that teacher input and voice are missing in many of these reform efforts and should be addressed (Kennedy, 2005; Ravitch, 2013). The U.S. Department of Education, in recognition of this problem, now has a program that involves teacher ambassadors in looking at policies (USDE, 2016). The Teachers' Perceptions of Reform Initiatives Survey in this study allows educators and policy makers to obtain input from teachers in West Virginia Title I schools about the use of reform initiatives proposed either nationally or through the West Virginia Department of Education.

\section{Summary}

This study developed a valid and reliable tool that measures teachers' uses and perceptions of national and West Virginia initiatives directed at the achievement gap for the low socioeconomic subset of children in West Virginia Title I schools. The research questions was: What are the psychometric properties of a survey instrument that is designed to assess teachers' perceptions of the uses and effectiveness of reform initiatives that have been implemented in high poverty schools to address the academic achievement of low-SES students in Title I schools? There were two phases: 1) the development of the instrument, and 2) establishing the 
validity and reliability of the instrument. The following sections will discuss the findings related to the instrument development and the validity and reliability of the survey which was developed.

Research Question. In Phase 1 the survey was developed. A review of the literature in Chapter 2 revealed that the low socioeconomic achievement gap continues to be a problem across the United States (Reardon, 2011). Poverty and its effect on academic achievement for poor children were examined and then formed the basis for the literature review. Sixteen reform initiatives were identified that both had a research base and were directed toward the achievement of poor children: universal preschool, afterschool programs, 21st Century Community Learning Centers, adding minutes/hours/days, teachers' high expectations, teaching resilience and coping skills, increased time in physical activity, arts education, high stakes summative testing, formative assessment, Response to Intervention, differentiated instruction, early screening, school based health centers and wraparound services, food and nutrition, and National Board Certified teachers. These initiatives were then assessed for validity through a panel of experts.

Validity. In Phase 2 validity and reliability were established. Validity measures the degree to which a survey measures what it is purported to measure. The reform initiatives, teacher demographics, and policy implementation factors were developed through a review of the literature as found in Chapter 2. Validity of a survey cannot be determined through quantitative methods so a panel of four experts was asked to evaluate the survey (Gay et al., 2009). Criteria for selection of panel members included: experience and/or familiarity with: atrisk and Title I children, reform initiatives to address the achievement gap of low-performing children, and survey development. This diverse group of educators included a West Virginia 
superintendent, an expert in survey methods, a Director of Title I for the West Virginia Department of Education, and a former principal and superintendent with experience working with at-risk children. The recommendations of the Panel of Experts are in Appendix H. Panelists agreed to keep all 16 reform initiatives. Modifications were made in a title, wording, grammar, and additional research for consistency. Panelists made no changes to the policy factors. Changes were made to demographics by the panel and by the dissertation committee. The committee added county to determine location of the reform initiative. Two additional demographic variables were suggested in a conversation with the panelists although they did not include them in their written comments. One was the addition of National Board Certification through NBPTS and one was the addition of Highest Education Degree Attained. The demographics section will allow for a separate analysis on how these factors affect teachers' perceptions in West Virginia Title I schools. Validity was established for the survey. The Teachers' Perceptions of Reform Initiatives Survey is then valid for this population-Teachers in West Virginia Title I schools and for the 16 reform initiatives as validated by the panel review.

Reliability. A survey of 26 teachers in a West Virginia elementary Title I school was used to establish reliability of the survey. Reliability is "the degree to which a test consistently measures whatever it is measuring" (Gay et al., 2009, p. 141). Individuals who were chosen to participate in the pilot survey should be similar to those for whom the survey is intended (Gay et al., 2009). Reliability was determined through a survey of 26 teachers who were of the same type of population as the larger target population; in this case, West Virginia teachers in Title I schools (Gay et al., 2009). The school was chosen because it was a Title I School, it was close to the researcher, and the researcher knew the administrator. Sixteen teachers returned the survey electronically over a one week time period. All of the 16 reform initiative reliability coefficients 
in the study were above .70 with 13 coefficients above .90 which means all 16 reform initiatives are acceptable. Arts education had the greatest reliability. The item 21 st Century Community Learning Centers had the lowest reliability coefficient, although since the coefficient was above .70 , it is considered to be acceptable. Of the 16 reform initiatives, 13 had a Cronbach's coefficient above .90 , which were considered excellent. One reform initiative had a coefficient at .898 , considered to be good, and two reform initiatives had coefficients at .758 and .749, considered to be acceptable. All of the coefficients indicated acceptable reliability (Table 1).

Cognitive interviewing. In order to check that the survey was understandable and easy to take and that there were no unexpected problems, a cognitive interview session was held with four teachers who volunteered to take the survey with the researcher. Although there were some questions, the teachers interpreted them as the researcher had intended. Teachers were familiar with all of the reform initiatives and liked the addition of the research included for each item. They felt that the reform initiatives included were those that they used or thought should be used to help the academic achievement of their Title I students. As a result of the Cognitive Interviews changes were made to the question stems for clarity (Appendix J). Results of the Cognitive Interviews can be found in in Table 2.

The development of the survey is shown in Appendix J. Changes were made by the panel of experts, the dissertation committee, and the results of the cognitive interviews. Reliability was established for all reform initiatives.

\section{Related Findings}

One survey question was analyzed in more depth because of its results. Teachers were asked, "Has this initiative improved the academic achievement of your students?" Although this 
was a survey of one school, an analysis of the means showed some interesting information about how these teachers perceived the effect of reform initiatives on academic achievement (Table 3). The academic achievement question had 15 out of 16 means all above 3.0. The reform initiative that had the lowest mean was High Stakes Standardized Testing with a 1.93 mean. This may indicate a perception by teachers in this survey that these reform initiatives, with the possible exception of High Stakes Standardized Testing, have improved academic achievement. The highest means were $21^{\text {st }}$ Century Community Learning Centers at 3.88, Teachers' High Expectations at 3.88, After School programs at 3.81, Teaching Resilience and Coping Skills at 3.80, Differentiated Instruction at 3.80, and Response to Intervention at 3.79. Three of these reform initiatives, Teachers' High Expectations; Teaching Resilience and Coping Skills; and Differentiated Instruction are more classroom based with teachers having more control over them. This school had a $21^{\text {st }}$ Century Community Learning Center in the school for many years and many teachers were familiar with or had worked in the program. All of these reform initiatives also had all implementation factor means above 3.0 except for one factor under Differentiated Instruction which was 2.82 under no major changes.

High Stakes Summative Testing which had the lowest means for perceptions of improving academic achievement also had the most implementation factors below 3.0: Input into Design, Input into Implementation, Consistent with Teacher's Belief, Easy to Implement, and Requires no Major Changes (Tables 4 and 5). Again, this may suggest to policymakers and administrators that reform initiatives may need to be implemented more carefully and comprehensively. This survey suggests that policy implementation factors may impact teachers' perceptions of improved academic achievement for their students. 
Standard deviations are also included and indicate the spread of the scores. Those reform initiatives where there was the lowest variance were $21^{\text {st }}$ Century Community Learning Centers with a variance of .13 and a standard deviation of .35; Teachers' High Expectations with a variance of .13 and a standard deviation of .35; After School Programs with a variance of .16 and a standard deviation of .40; and Differentiated Instruction with a variance of .17 and a standard deviation of .40 . Those reform initiatives with the most spread out scores were Food and Nutrition with a variance of 1.30 and a standard deviation of 1.70; National Board Certified Teachers with a variance of 1.47 and a standard deviation of 1.21; and High Stakes Summative Testing with a variance of 1.30 and a standard deviation of 1.14. This type of information could be helpful as educators and policy makers look at the impact of reform initiatives as perceived by teachers who are using them in their schools and classrooms. Are scores for an initiative spread out and if so are very high or very low scores affected by teacher demographics? Do experienced teachers have different perceptions then less experienced teachers about reform initiatives that are newly implemented? Do teachers' demographics affect the perceptions of teachers about these reform initiatives in West Virginia Title I schools?

Another finding is related to policy implementation factors. Tables 4 and 5 list the nine policy implementation questions as they appear in the logic display menu in the survey. The statement factors are listed in Appendix A. The implementation factors were: necessary training; necessary materials; necessary time; design input; input into implementation; collaboration opportunities; initiatives that are consistent with teachers' beliefs; initiatives that are easy to implement; and initiatives that require no major changes.

Eight reform initiatives had means at or above 3.0 for all 9 implementation factors. These reform initiatives had at least one implementation factor mean below 3.0: Adding 
Minutes/Hours/Days, High Stakes Summative Testing, Response to Intervention, Differentiated Instruction, Early Screening, School Based Health Centers, Food and Nutrition, and National Board Certified Teachers. The reform initiatives 21st Century Community Learning Centers and After School Programs had eight of the nine implementation factors means above 3.50. Increased Time in Physical Activity; Arts Education; High Stakes Summative Testing; School Based Health Centers and Wraparound Services;, and Food and Nutrition had no implementation factors with means at or above 3.5

The implementation factor, Training, had means above 3.0 for all reform initiatives. The implementation factors with the most means below 3.0 for reform initiatives were: Input into Design with means lower than 3.0 for Adding Minutes/Hours/Days/Time to School Calendar, High Stakes Summative Testing, School Based Health Centers and Wraparound Services, and Food And Nutrition; Easy to Implement with means lower than 3.0 for High Stakes Summative Testing, Response to Intervention, Differentiated Instruction, and National Board Certified Teachers; and Input into Implementation with means lower than 3.0 for High Stakes Summative Testing, School Based Health Centers and Wraparound Services, and Food and Nutrition.

High Stakes Summative Testing was the lowest in teachers' perceptions of improving academic achievement with a mean of 1.93 and had five implementation factors below 3.0. The reform initiative 21st Century Community Learning Centers had the highest teachers' perceptions of improving academics with a mean of 3.88 and also had 8 of 9 implementation factors above 3.5 with the ninth at 3.43 and the only perfect 4.0 for Consistent with Beliefs. After School programs had a mean of 3.81 for improving academic achievement and had 8 of 9 policy implementation means above 3.5. Four of the top five highest means in teachers' perceptions of 
reform initiatives improving academic achievement had no policy implementation factors below 3.0 .

The policy implementation factors with the most means below 3.0 were Input into Design of reform initiatives, Easy to Implement, and Input into Implementation of reform initiatives. The policy implementation factor Training had all means above 3.0.

The reform initiatives and policy implementation factors may give school administrators and policy makers a better idea of why teachers' perceptions about reform initiatives' positive impacts on academic improvement for their students are high or low. Educators and policy makers could examine survey results to determine if implementation factors may be making a difference in the success of reform initiatives.

\section{Discussion}

Many school reforms and instructional policy initiatives have been proposed and instituted in U.S. schools. The federal government has funneled money and resources into special programs such as Title I and Head Start. Federal emphasis has shifted from equity-based reforms to standards-based reforms, and to standardized test-driven reforms. Charter schools and vouchers have been tried and have not shown any dramatic difference (Gleason et al., 2010; National Education Association, 2014). Classrooms and schools are often the places where initiatives directed toward improving achievement occur.

Teacher leaders and educators have the most control over these school and classroom strategies. Yet, teachers are seldom asked about their perceptions of these reform initiatives. Are proposed initiatives being used? Do teachers believe they improve achievement? Are teachers prepared for and accepting of these programs and reform initiatives? Currently there are few 
instances when teachers have been asked these questions in a format that can then be statistically analyzed and shared with policy makers, teacher leaders, and educators. This survey instrument was based on reform initiatives that have a broad base of research and a West Virginia recommended component. Teachers can also give their perceptions of possible reasons that reform initiatives are or are not working by answering a set of questions about factors that have been shown to affect implementation: materials, time, training, ease of implementation, input from teachers on the design and implementation, and whether these reform initiatives are in line with school and teacher beliefs.

The purpose of the study was to develop a valid and reliable tool that measured teachers' uses and perceptions of national and West Virginia initiatives directed at the achievement gap for the low socioeconomic subset in West Virginia Title I schools. The report, The West Virginia Closing the Achievement Gap report for $21^{\text {st }}$ Century Learners was instrumental in looking at the research by the West Virginia Department of Education and its recommendations for the low socioeconomic achievement gap (WVDE, 2009). The final 16 reform initiatives to be used in the survey were chosen after multiple drafts. Fourteen of these had also been recommended in some form in the WVDE report. Nine research based implementation factors shown to affect implementation were chosen. Teachers are also asked if initiatives have improved the academic achievement of their students. Demographic variables in the survey were those that had been determined to affect teachers' perceptions in a Georgia study of similar reforms (Page \& Page, 1990. Two additional demographics were added by the panel. The committee added county.

Validity was established through a review by a panel of experts. These experts were given the survey, a chart showing the linkage between the reform initiative and the research, the 
literature review, references, and a chart for recording their comments. Each was asked if the initiative should be kept, deleted, or modified. The panelists' comments were reviewed carefully and each concern was addressed (Appendix G). Telephone calls were made when there was any ambiguity. Two panelists who had asked for added research or more in depth changes were sent the results of those changes. The panelists chose to keep all initiatives with modifications as listed in Appendix G. This examination of the literature review and the reform initiatives and factors by the panel of experts established the reliability of this survey.

The survey was conducted using a Qualtrics survey sent to 26 teachers in a West Virginia Title I school. Of the 26 surveys distributed, 16, or $61.5 \%$ were returned within the one week timeframe. The reliability coefficients, determined through a split-half method, for the reform initiatives were all above .70 which is considered acceptable.

Reliability was determined for each initiative and factor. All reliability coefficients showed internal consistency. The National Board Certified Teachers initiative did not have $\mathrm{n}=10$, but nevertheless showed a very high reliability coefficient. Cognitive interviews were held to pretest the survey for comprehension and readability.

Although any analysis of means are for this limited study only, it is interesting to see the results of this survey study in the area of teachers' perceptions of how reform initiatives have improved the academic achievement of their Title I students and how they perceive the policy implementation factors for these reform initiatives.

These tables demonstrate the types of information that could be used to examine initiatives. If all policy implementation factors are high meaning teachers feel they have the necessary training, time, resources and the belief that they have had input into implementation 
and design of initiatives but academic achievement is rated low, then that may mean looking at the initiative itself. If implementation factors are low, and the initiative rates low in increasing academic achievement, then, perhaps, teachers need more help in implementing initiatives. If teachers say initiatives are not being used, then it may be necessary to explore why. This information on the use of initiatives is especially important when the initiatives have been prescribed for inclusion in the counties and schools. Giving this information to superintendents would be an important check on the realities of the inclusion of reform initiatives in specific schools. Regional Education Service Agencies in West Virginia could look at those schools and counties that are not meeting benchmarks or goals for information and possible ways to improve or ensure implementation of recommended or prescribed reform initiatives through staff development and training. The information on policy implementation factors also can provide specific factors that may improve successful implementation.

\section{Recommendations for Survey Administration}

The Teachers' Perceptions of Reform Initiatives Survey was designed to measure teachers' use and perceptions of initiatives for the low socioeconomic subset in West Virginia Title I schools by surveying all teachers in Title I schools, including Title I specialists, in 344 Title I schools in West Virginia.

\section{Recommended Data Analysis for the Survey}

There are four questions that can be answered by the instrument. The first is "What initiatives directed toward improving academic achievement of the low socioeconomic subset have West Virginia teachers in Title I schools used in their schools?" This will be a descriptive 
analysis and will be determined by calculating means and standard deviations for each initiative and frequency.

The second question, "According to teachers in West Virginia Title I schools, have these reform initiatives improved the achievement of their students?" would be analyzed by calculating means and standard deviations for each item and following the process used for question one. Percentages of respondents who answered at each level for each initiative would also be calculated.

The third question is "How do teachers in West Virginia Title I schools perceive nine implementation factors?" It would be analyzed by calculating means and standard deviations for each item and following the process used for questions one and two.

The fourth question is "Is there a significant difference between selected demographics and teacher perceptions of initiatives directed at improving the academic achievement of their students in West Virginia Title I schools?" The demographics section of the survey will ask for the following demographic information: programmatic level; age; gender; years of experience; National Certification through the National Board for Professional Teaching Standards; and highest education degree attained. There will be a place to write in county. There are subquestions under each demographic linking it to initiatives that have shown significant differences in a Georgia study (Page \& Page, 1990).

\section{Recommendations for Survey Design}

During the cognitive interviews teachers did not have any concerns about the answer choices, wording, or instructions. However, there was some confusion about use in classroom and use in school with some of the initiatives so future users of the survey may want to check 
that this is understood. Although the item National Board Certified Teacher had a low number of those who said they used this initiative, the Cronbach's alpha was still high at .898. This item may have low reported use in one school and very high in another due to the presence or absence of nationally certified teachers. For non-board certified teachers, (three of four who took the cognitive interviewing) judging this item seemed more difficult.

The indicator, I use this initiative, excluded information from those who may have had the initiative in the past and some strong perceptions about it. For example, this school lost their 21st CCLC afterschool program and those teachers who were interviewed had strong feelings about the initiative, but they were not using this initiative when completing the survey. Including examples, definitions, and research for the initiatives was helpful according to those teachers who participated in the cognitive interviews.

Fowler (2009) contends that all policies and initiatives should be evaluated and that policy makers should act on the findings by modifying, and even terminating, those that do not work. This survey instrument allows policy makers and education leaders to assess how teachers view reform initiatives, whether they are using them and whether they think they contribute to academic achievement (Fowler, 2009). These perceptions can be part of dialogues that occur on all levels of initiative development and implementation. An added feature of the instrument is that it will give these policy makers and leaders some insight into possible reasons that an initiative, according to teachers, does not appear to be working. Factors that enable or facilitate implementation may not be present. Teachers may believe that they have not had necessary training, or materials. When spending priorities become an issue, policy makers and education leaders will have some information that, coupled with other data, may help decide budget priorities. Perhaps additional materials and training are merited. For example, National Board 
Certified Teachers receive support from the legislature. School Faculty Senates receive money to use for supplies. This ability to collect and analyze data about education initiatives is especially important in a state with a legislature that is highly "unprofessionalized" (Fowler, 2009, p. 145) with little support staff who can research and inform legislators about education issues. These "unprofessionalized" legislatures also have shorter sessions. Information that contains information in a format that can be analyzed and presented to policy makers may help them understand issues. Education leaders can look at results and make decisions about requesting more funding for initiatives.

This instrument has been designed to measure teachers' perceptions in West Virginia Title I schools. The reform initiatives, demographics, and policy implementation factors have been drawn from a national review of literature. The 16 reform initiatives that were included in the survey have been found to be effective as reported in the research literature (Appendix C). Looking at the differences between rural and urban results, large versus small cities, or other indicators may give some insight into the success and use of proposed initiatives. It should be noted that any changes to the survey would require revalidation of the instrument.

Results could be valuable to lobbying for or against implementing and funding education initiatives. For example, if there is a broad approval of increased physical education or arts education, those might become a priority for addition into schools' curricula. Administrators may use findings to determine what implementation factors are missing. More training, more implementation time, or more information about the policy or initiative may improve its effectiveness. Faculty Senates could use this information to develop goals and agendas. 


\section{Recommendations for Future Research}

It is recommended that this survey be sent to all teachers in West Virginia Title I schools, and that analyses be made of teachers' uses of reform initiatives, perceptions of implementation factors, perceptions of the effects of reform initiatives on academic achievement of students, and the effects of demographics on perceptions. Modifications can be made for West Virginia teachers by adding or deleting demographic variables depending on the information that is being collected. Administrators may want to know about just those reform initiatives recommended for their schools or may want to include only certain implementation factors. Currently there is a designation for county but this could be further modified to ask for school or RESA or eliminated for greater anonymity. Although teachers had an opportunity for comments on each reform initiative, a more in-depth follow-up of this survey through interviewing would be important in discovering why teachers have answered as they have. The policy implementation factors could be expanded to include needed information about a particular policy or policies. An example might be year round school or ungraded classrooms. The survey could be adjusted for parents and students by revalidating the survey for other populations, implementation factors and initiatives and then assessing for perceptions of extra learning time, more arts and physical education, the importance of nutrition programs and other initiatives. Surveys could be designed to measure initiatives recommended for other subsets including special education, English Language Learners and African Americans, all subsets that have been identified as low achieving in the West Virginia Closing the Achievement Gap Report for $21^{\text {st }}$ Century learners (WVDE, 2009). In 2011-2012 there were 44,487 special education students and 13,651 African American students in West Virginia (WVDE, 2016a). 


\section{Conclusion}

This study developed a valid and reliable survey, Teachers' Perceptions of Reform Initiatives (Appendix K), to measure teachers' uses and perceptions of national and West Virginia reform initiatives directed at decreasing the achievement gap for the low socioeconomic students in West Virginia Title I schools. Reliability was determined through a split-half method using Cronbach's Alpha with all factors and initiatives determined to be above .70. The survey contains 16 reform initiatives that have been shown to affect the academic achievement of low SES children. These initiatives are in four categories: extended time, classroom strategies, supplemental services, and other influences on students' academic success, achievement, and well-being. The survey also gathers data on seven demographics: programmatic level, years of experience, age, gender, National Board Certification through the NBPTS, highest education degree attained, and county. The Teachers' Perceptions of Reforms Initiatives Survey may provide some guidance as to why some initiatives do or do not work and those factors that may be related. This instrument with further validation can be adapted for different populations of teachers in West Virginia and for different initiatives as education officials and policy makers search for answers to the academic achievement gap between the low socioeconomic child and her more affluent peers. 


\section{References}

Almeida, D. M., Neupert, S. D., Banks, S. R., \& Serido, J. (2005). Do daily stress processes account for socioeconomic health disparities? Journal of Gerontology Series B: Psychological Sciences and Social Sciences, 60(2), 34-39. Retrieved from http://www.midus.wisc.edu/findings/pdfs/276.pdf

Andrews, M. (2011, September 12). School-based health clinics play vital role in children's' lives. Los Angeles Times. Retrieved from http://articles.latimes.com/2011/sep/12/health/la-he-clinics-in-schools-20110912

Barton, P. E., \& Coley, R. J. (2003). Parsing the achievement gap. ETS Policy Information Center Report. Retrieved from http://www.ets.org/Media/Research/pdf/PICPARSINGII.pdf

Baydar, N., Brooks-Gunn, J., \& Furstenberg, F. (1993). Early warning signs of functional illiteracy. Predictors in childhood and adolescence. Child Development, 64(3), 815-829.

Berliner, D. C., \& Biddle, B. J. (1995). The manufactured crisis. Reading, MA: Perseus Books.

Berliner, D. C., \& Glass, G. V. (2014). Myths \& lies that threaten America's public schools. New York, NY: Teachers College Press.

Bernard, B. (2004). Resiliency: What we have learned. San Francisco, CA: WestEd.

Borman, G. D., Rachuba, L. T., \& Center for Research on the Education of Students Placed At Risk, B. D. (2001, February 1). Academic success among poor and minority students: An analysis of competing models of school effects. [serial online]. Available from: ERIC, Ipswich, MA. Retrieved from http://files.eric.ed.gov/fulltext/ED451281.pdf 
Boulay, B., Gamse, B., Checkoway, A., Maree, K., Fox, L., \& Society for Research on Educational Effectiveness. (2011). Evaluation of Massachusetts expanded learning time (ELT) initiative: Implementation and outcomes after four years. Society for Research on Educational Effectiveness. Retrieved From http://files.eric.ed.gov/fulltext/ED518868

Bradley, R. H., \& Corwyn, R. E. (2002, February). Socioeconomic status and child development. Annual Review of Psychology, 53, 371-300.

Bradley, R. H., Whiteside-Mansell, L., Mundfrom, D. J., Casey, P. H., Kelleher, \& K. J., Pope, S. K. (1994). Early indications of resilience and their relation to experiences in the home environments of low birth weight, premature children living in poverty. Child Development, 65(2), 346-360.

Brooks-Gunn, J., Guo, G., \& Furstenberg, F. (1993). Who drops out of and who continues beyond high school? Journal of Research on Adolescence, 3(3), 271-294.

Brown v. Board of Educ., 347 U.S. 483 (1954).

Carpenter, (1989). Using knowledge of children's mathematics thinking in classroom teaching: An experimental study. American Educational Research Journal, 26(4), 499-531.)

Castrachini, S, \& London, R.A. (2012). Positive student outcomes in community schools. Center for American Progress. Retrieved from ERIC (ED535614).

Cavalluzzo, L. (2004, November). Is national board certification an effective signal of teacher quality? (National Science Foundation Grant REC-0107014). Retrieved from ERIC (ED485515). 
Center for Disease Control and Prevention. (2010). The association between school based physical activity including physical education and academic performance. Retrieved from http://www.cdc.gov/healthyYouth/health_and_academics/pdf/pa-pe_paper.pdf

Center for Research on Education Outcomes. (2015). Overview of the urban charter school study. Retrieved from http://urbancharters.stanford.edu/overview.php

Coleman, J., Campbell, C. J., McPartland, J., Mood, A. M., Weinfeld, F. D., \& York, R. L. (1966). On equality of educational opportunity (Report No. OE-38001). Retrieved from http://files.eric.ed.gov/fulltext/ED012275.pdf

Collins, D. (2003). Pretesting survey instruments: An overview of cognitive methods. Quality of Life Research, 12, 229-238.

Cohen, D. K., \& Spillane, J. P. (1992). Policy and practice: The relations between governance and instruction. Review of Research in Education, 18, 3-49.

Crawford, A. (2013, June 2). Should the school year be longer? A large-scale study throws cold water on a popular idea. The Boston Globe. Retrieved from http://www.bostonglobe.com/ideas/2013/06/01/should-school-yearlonger/yHLI249RXCOfVVHWe1g9pO/story.html

Currie, J., \& Duncan, T. (1998). School quality and the longer-term effects of Head Start. Journal of Human Resources, 35(4) 755-774.

Currie, J., \& Thomas, D. (1995, June) Does Head Start make a difference? The American Economic Review, 85(3), 341-364. 
Daugherty, S. D., Harris-Kojetin, L., Squire, C., \& Jael, E. (2001, August 5-9). Maximizing the quality of cognitive interviewing data: An exploration of three approaches and their informational contributions. Proceedings of the Annual Meeting of the American Statistical Association. Retrieved from http://www.amstat.org/sections/srms/Proceedings/y2001/Proceed/00343.pdf

DeGarmo, D. S., Forgatch, M. S., \& Martinez, C. R. ((1999). Parenting of divorced mothers as a link between social status and boys' academic outcomes. Unpacking the effects of socioeconomic status. Child Development, 70, 1231-1245

Dillman, D. A., \& Redline, C. D. (2004). Testing paper self-administered questionnaires: Cognitive interview and field test comparisons. In Presser, S., Rothgeb, J. M., Couper, M. P., Lessler, J. T., Martin, E., Martin, J. \& Singer, E. (Eds.), Methods for testing and evaluating survey questionnaires (pp. 299-317). Hoboken: Wiley \& Sons, Inc.

Drazen, S. (1992, April). Student achievement and family and community poverty: Twenty years of education reform. Paper presented at the Annual Meeting of the Eastern Psychological Association, Boston, MA.

Duncan, G J. \& Magnuson, K. (2011). The nature and impact of early achievement skills, attention skills, and behavior problems. In Duncan, G. J., \& Murnane, R. J (Eds.) Whither Opportunity (pp. 47-70). New York, NY: Russell Sage Foundation.

Dweck, C. (2015, September 22). Carol Dweck revisits the growth mindset. Education Week. Retrieved from http://www.edweek.org/ew/articles/2015/09/23/carol-dweck-revisits-thegrowth-mindset.html 
Esposito, L. (2014, January 2). Re: What one urban school district can teach the country about stress relief [Web log message]. Retrieved from http://www.huffingtonpost.com/lindaesposito-lcsw/urban-school-meditation_b_4519576.html

Evans, G. W. (2004). The environment of childhood poverty. Developmental Psychology, 39(5), 924-933.

Evans, G. W., Wells, N. M., \& Moch, A. (2003). Housing and mental health: A review of the evidence and a methodological and conceptual critique. Journal of Social Issues, 59(3), 475-500.

Farah, M. J., Shera, D. M., Savage, J. H., Betancourt, L., Giannetta, J. M., Brodsky, N. L., Betancourt, L., Giannetta, J. M., Brodsky, N. L., Malmud, E. K., \& Hurtet, H. (2006). Childhood poverty: Specific associations with noncognitive development. Brain Research, 1110(1), 166-174.

Ford, S. (2013). Good Nutrition Links to Academic Success. Education Digest 79(1), 56-58. Academic Search Alumni Edition, EBSCOhost.

Fowler, F. C. (2009). Policy studies for educational leaders (3rd ed.). Boston, MA: Pearson.

Frank Porter Graham Child Development Institute. (2014). The abecedarian project. Retrieved from http://abc.fpg.unc.edu/

Fuchs, D. (1991). Effects of curriculum-based measurement and consultation on teacher planning and student achievement in mathematics operations. American Educational Research Journal, 28(3), 617-641. 
Gay, L. R., Mills, G. E., \& Airasian, P. (2009). Educational research: Competencies for analysis and applications $\left(9^{\text {th }}\right.$ ed.). Upper Saddle River, NJ: Pearson Education, Inc.

George, D., \& Mallery, P. (2003). SPSS for Windows step by step: A simple guide and reference. 11.0 update (4th ed.). Boston, MA: Allyn \& Bacon.

Gewertz, C. (2007, September 10). High achieving students in low-income families said likely to fall behind. Education Week. Retrieved from http://www.edweek.org/ew/articles/2007/09/10/03poor_web.h27.html?qs=gewertzwww.ed week.org

Gleason, P., Clark, M., Tuttle, C. C., \& Dwoyer, G. (2010). The evaluation of charter school impacts: Final report (NCEE 2010-4029). Washington, DC: National Center for Education Evaluation and Regional Assistance, Institute of Education Sciences, U.S. Department of Education. Retrieved from http://ies.ed.gov/ncee/pubs/20104029/pdf/20104029.pdf

Good Food =Good Grades. (2008). "Good food = good grades." Better Nutrition 70(9), 14. Academic Search Complete, EBSCOhost (accessed April 1, 2016).

Gottfried, A. W., Gottfried, A. E., Bathurst, K., Guerin, D. W., \& Parramore, M. M. (2003). Socioeconomic status in children's development and family environment: Infancy through adolescence. In M. H. Bornstein \& R. H. Bradley (Eds.), Socioeconomic status, parenting, and child development (pp. 260-285). Mahwah, NJ: Lawrence Eribaum Associates.

Gottleib, D. J., Beiser, A. S., \& O’Conner, G. T. (1995). Poverty, race, and medication use are correlates of asthma hospitalization rates: A small area analysis in Boston. Chest, 108(1), 28-35. 
Grace, E., Thomas, D., \& Currie, J. (2000). Longer effects of Head Start (NBER Working Paper No. 8054). Cambridge, MA: National Bureau of Economic Research.

Grissmer, D., Flanagan, A., \& Williamson, S. (1998). Why did the black-white score gap narrow in the 1970s and 1980s. In C. Jencks, \& M. Phillips (Eds.), The black white test score gap (pp. 182-226). Washington, DC: The Brookings Institution.

Haeger, H., Lambert, A. D., Kinzie, J., \& Gieser, J. (2012, June). Using cognitive interviews to improve survey instruments. Paper presented at the annual forum of the Association for Institutional Research, New Orleans, Louisiana. Retrieved from http://cpr.indiana.edu/uploads/AIR2012\%20Cognitive\%20Interviews.pdf

Harris, J. R. (2006). No two alike. New York: W. H. Norton.

Hazi, H. M. (1983, September). Judge defines quality education for schools. Educational Leadership. 41(1), 68-69.

Hazi, H. (1985). Co-Rechting West Virginia public schools. Educational Leadership, 42(6), 7578.

Hedges, L. V., \& Nowell, A. (1998). Black-white test score divergence since 1965. In C. Jencks \& M. Phillips (Eds.) The black-white test score gap (pp.149-181).Washington, DC: Brookings Institution.

Hellmich, N. (2010, April 14). Study: Physical activity can boost student performance. USA Today. Retrieved from http://usatoday30.usatoday.com/news/education/2010-04-14letsmoveinschool15_ST_N.htm

Hill, R. (1998). What sample size is "enough" in internet survey research? Interpersonal Computing and Technology: An Electronic Journal for the 21st Century, 6(3-4). 
Homeroom. (2012). Teacher cabinets: Bringing teacher voice to the education reform process [Web log message]. Retrieved from http://www.ed.gov/blog/tag/teaching-ambassadorfellows/page/3/

Institute for Digital Research and Education (2015). SPSS FAQ: What does Cronbach's alpha mean? Retrieved from http://www.ats.ucla.edu/stat/spss/faq/alpha.html

Institute for Research on Poverty. (2014). What are poverty thresholds and guidelines? Retrieved from http://www.irp.wisc.edu/faqs/faq1.htm

Isaac, S., \& Michael, W. B. (1995). Handbook in research and evaluation. San Diego, CA: Educational and Industrial Testing Services.

Jencks, C. \& Phillips, M. (Eds.). (1998.) The black-white test score gap. Washington, DC: Brookings Institute Press.

Jennings, J. (2000). An education agenda for the congress and the new administration. Paper presented at the December 2000 convention of the Center on Education Policy. Retrieved from http://www.cep-dc.org/meetings/index.cfm?selectedYear=2001

Jennings, J. (2012). Reflections on a half-century of school reform: Why have we fallen short and where do we go from here? Paper presented upon retirement to the Center on Education Policy, Washington, DC: CEP. Retrieved from http://www.cepdc.org/displayDocument.cfm?DocumentID=392

Jensen, E. (2009). Teaching with poverty in mind. Alexandria, VA: ASCD.

Jobe, J. B. (2003). Cognitive psychology and self-reports: Models and methods. Quality of Life 
Research, 12, 219-227.

Johnson-Staub, C. (2014, Oct.) First steps for early success: State strategies to support developmental screening in early childhood settings. Center for Law and Social Policy, Inc. Retrieved from Eric (ED561731).

Jonides, J. (2008). Musical skill and cognition. In Asbury, C., \& Rich, B. (Eds.), Language, arts, and the brain (pp. 11-17). New York: Dana press. Retrieved from http://www.dana.org/uploadedFiles/News_and_Publications/Special_Publications/Learning \%20Arts\%20and\%20the\%20Brain_ArtsAndCognition_Compl.pdf

Karoly, L. A. (2001). Changes in family structure: Implications for poverty and related policy. In Danzinger, S. H., \& Haveman, R. H. (Eds.), Understanding poverty (pp. 314-356). New York: Russell Sage Foundation.

Kearns, L. (2011). High-stakes standardized testing and marginalized youth: An examination of the Impact on those who fail. Canadian Journal of Education / Revue canadienne de l'éducation, 34(2), 112-130. Retrieved from http://www.jstor.org.www.libproxy.wvu.edu/stable/pdf/canajeducrevucan.34.2.112.pdf? $=1462123741310$

Kennedy, M. (2005). Inside teaching. Cambridge, Mass: Harvard University Press.

Kids Count. (2015). Kids count data center. Retrieved from the Annie B. Casey Foundation website: http://datacenter.kidscount.org/data\#WV/2/0 
Kids Count Data Book Ranks WV 43 in the Country for Child Well-Being. (2015, July 21). The State Journal. Retrieved from http://www.statejournal.com/story/29598372/2015-kidscount-data-book-ranks-wv-43-in-the-country-for-child-well-being

Kiely J. L., \& Kogan, M. D. (1994). Prenatal care. In: Wilcox L. S., \& Marks, J. S., (Eds.), From data to action. CDC's public health surveillance for women, infants, and children (pp. 105-118). Atlanta, GA: U.S. Department of Health and Human Services, Public Health Service, Centers for Disease Control and Prevention.

Kisida, B., Greene, J. P., \& Bowen, D. H. (2013, November 23). Art makes you smart. The New York Times. Retrieved from http://www.nytimes.com/2013/11/24/opinion/sunday/artmakes-you-smart.html?emc=edit_tnt_20131124\&tntemail0=y\&_r=1\&

Kiviat, B. J. (2000, April). The social side of schooling. John Hopkins Magazine. Retrieved from http://pages.jh.edu/ jhumag/0400web/18.html

Klotz, M. B., \& Canter, A. (2007) Response to intervention: A primer for parents. Retrieved from http://www.nasponline.org/resources/handouts/revisedPDFs/rtiprimer.pdf

Labree, R.V. (2016, May). Organizing your social sciences research paper. USC Libraries. Retrieved from http://libguides.usc.edu/srch.php?tag=citation\&default_lg=1

Ladson-Billings, G. (2006, October). From the achievement gap to the education debt: Understanding achievement in U.S. schools. Educational Researcher, 35(7) 3-12. Retrieved from http://www.jstor.org/stable/3876731 
Larossi, G. (2006). The power of survey design: A user's guide for managing surveys, interpreting results, and influencing respondents. Washington, D.C: The World Bank.

Lau v. Nichols, 414 U.S. 563 (1974).

Laureau, A. (2011).Class, race, and family life (2nd ed.). Berkeley, CA: University of California Press, Ltd.

Laurer, P. A., Akiba, M., Wilkerson, S. B., Apthorp, H. S., Snow, D., \& Martin-Glenn, M. L. (2006, Summer). Out-of-school-time programs: A meta-analysis of effects for atrisk students. Review of Educational Research, 76(2), 275-313.

Liaw, F. R., \& Brooks-Gunn, J. (1994). Cumulative familial risks and low birth-weight children's cognitive and behavioral development. Journal of Clinical Child Psychology, 23(4), 360-372.

Lichter, D. T. (1997, August). Poverty and inequality among children. Annual Review of Sociology, 23, 121-145.

Little, P. M. D., Wimer, C., Weiss, H. B., \& Harvard Family Research Project. (2008). After school programs in the 21st century: Their potential and what it takes to achieve it. Retrieved from http://www.hfrp.org/publications-resources/publicationsseries/issues-and-opportunities-in-out-of-school-time-evaluation/after-schoolprograms-in-the-21st-century-their-potential-and-what-it-takes-to-achieve-it

Louisiana Public Health Institute. (2010). Evaluation study: SBHCs making a difference. Retrieved from http://phi.org/home2/section/3-30-32-90-326/evaluation$\underline{\text { study\%3A--sbhcs-making-a-difference }}$ 
Ludwig, J., Phillips, D., \& Society for Research in Child Development. (2007). The benefits and costs of Head Start: Social policy report. Society for Research in Child Development. Retrieved from http://srcd.org/sites/default/files/documents/21$\underline{3 \_ \text {early_childhood_education.pdf }}$

Lugalia, T. (2003). A child's day: Selected indicators of child well-being. Retrieved from http://www.census.gov/prod/2003pubs/p70-89.pdf

Mansell, W. (2010, February 16). Re: Children can fall behind as early as nine months [Web log message]. Retrieved from http://www.theguardian.com/society/2010/feb/17/children-fall-behind-nine-months

Maskill, M. (2012). "Study of the Effectiveness of Response to Intervention Used in Elementary School" Master's Theses and Doctoral Dissertations. Paper 449.

Matte, T. D., \& Jacobs, D. E. (2000). Housing and health-current issues and implications for research and programs. Journal of Urban Health, 77(1), 7-25.

McCord, C., \& Freeman, H. P. (1990). Excess mortality in Harlem. New England Journal of Medicine, 3(322), 173-177.

McCoy, M B., Frick, P. J., Loney, B. R., \& Ellis, M. L. (1999). The potential mediating role of parenting practices in the development of conduct problems in a clinicreferred sample. Journal of Child and Family Studies, 8(4) 477-494.

Menyuk, P. (1980). Effect of persistent otitis media on language development. Annals of Otology, Rhinology, and Laryngology Supplement, 89(3), 257-263.

Merritt, E. G., Rimm-Kaufman, S. E., Berry, R. Q., Walkowiak, T. A., Larsen, R. A., \& Society for Research on Educational Effectiveness. (2011). The contribution of 
mathematics instructional quality and class size to student achievement for third grade students from low income families. Retrieved from http://files.eric.ed.gov/fulltext/ED528919.

National Board for Professional Teaching Standards. (2014). What if every teacher in America was expected to be board-certified? Retrieved from NBPTS website: http://www.nbpts.org/our-vision

National Board for Professional Teaching Standards. (2015). Mission. Retrieved from the NBPTS website: http://www.nbpts.org/mission

National Center for Education Statistics. (2014). Achievement gaps. Retrieved from http://nces.ed.gov/nationsreportcard/studies/gaps/

National Conference of State Legislatures. (2014). School vouchers. Retrieved from http://www.ncsl.org/research/education/school-choice-vouchers.aspx

National Education Association. (2014). School vouchers: The emerging track record. Retrieved from the NEA website: http://www.nea.org/home/16970.htm

National Longitudinal Surveys. (2006). Retrieved from http://www.bls.gov/nls/y97summary.htm

Nationwide Children's. (2015). Early screening and diagnosis. Retrieved from the Nationwide Children's website at http://www.nationwidechildrens.org/autism-early$\underline{\text { screening-and-diagnosis }}$

Nelson, C. A., \& Sheridan, M. A. (2011). Lessons from neuroscience research for understanding causal links between family and neighborhood characteristics and educational outcomes. 
In Duncan, G. J., \& Murnane, R. J (Eds.) Whither Opportunity (pp. 27-46). New York, NY: Russell Sage Foundation.

New York Performance Standards Consortium. (2014). Education for the $21^{\text {st }}$ century: Data report on the New York Performance Standards Consortium. Retrieved from http://performanceassessment.org/articles/DataReport_NY_PSC.pdf

Page, F. M., \& Page, J. A. (1990, April). Teachers' perceptions of the teaching profession and educational reform. Paper presented at the American Educational Research Association's Annual Meeting, Boston, MA.

Pate-Bain, H., Boyd-Zaharias, J., Cain, V. A., Word, E., \& Binkley, M.E. (1997, September 2). STAR follow-up studies, 1996-1997: The student/teacher achievement ratio (STAR) project. Retrieved from http://files.eric.ed.gov/fulltext/ED419593.pdf

Pauley et al. v Bailey et al, Civil Action No. 75-1268, Circuit Court, Kanawha County, West Virginia, May 14, 1982: 100.

Rahadkrishna, R. (2007). Tips for developing and testing questionnaires/instruments. Journal of Extension, 45(1). Retrieved from http://www.joe.org/joe/2007/february/tt2.phs

Ransford-Kaldon, C., Flynt, E., Ross, C., \& Society for Research on Educational Effectiveness. (2011). A randomized controlled trial of a response-to-intervention (RTI) tier 2 literacy program: Leveled literacy intervention (LLI). Society for Research on Educational Effectiveness. Retrieved from ERIC: http://files.eric.ed.gov/fulltext/ED518772.pdf 
Ravitch, D. (2007). Edspeak: A glossary of education terms, phrases, buzzwords, and jargon. Alexandria, VA: ASCD.

Ravitch, D. (2013). Reign of error. New York: Knopf.

Reardon, S.F. (2011). The widening achievement gap between the rich and the poor: New evidence and possible explanation. In Duncan, G. J., \& Murnane, R. J (Eds.) Whither Opportunity (pp. 91-116). New York: Russell Sage Foundation.

Research Institute on Poverty. (2014). What are poverty thresholds and guidelines? Retrieved from the Research Institute on Poverty website at http://www.irp.wisc.edu/faqs/faq1.htm

Rhem, J. (Ed.). (1999). Pygmalion in the classroom. The National Teaching and Learning Forum. 8(2). Retrieved from http://www.ntlf.com/issues/v8n2/v8n2.pdf

Rock, M., Gregg, M., Ellis, E., \& Gable, R. A. (2008). REACH: A framework for differentiating classroom instruction. Preventing School Failure, 52(2), 31-47.

Rosen, J. A., Glennie, E. J., Dalton, B. W., Lennon, J. M., and Bozick, R. N. (2010, September). Noncognitive skills in the classroom: New perspectives on educational research. RTI Press publication No. BK-0004-1009. Research Triangle Park, NC: RTI International. Retrieved from RTI International. Retrieved from http://www.rti.org/rtipress.

Rosenthal, R., \& Jacobsen, L. (1968). Pygmalion in the classroom: teacher expectation and pupils' intellectual development. New York: Holt, Rinehart and Winston.

Rosenthal, R. \& Jacobson, L. (1992). Pygmalion in the Classroom: Teacher Expectation and Pupils' Intellectual Development (Expanded edition). New York: Irvington Publishers 
Rothstein, R. (2008, April 7). Re: A “nation at risk” twenty-five years later [Web log message]. Retrieved from http://www.cato-unbound.org/2008/04/07/richard-rothstein/a-nation-at$\underline{\text { risk-twenty-five-years-later }}$

Rutter, M., Moffitt, T. E., \& Caspi, A. (2006). Gene environment interplay and psychopathology. Multiple varieties but real effects. Journal of Child Psychology and Psychiatry, 47(3-4) 226-261,

Sapolsky, R. (2005). Sick of poverty. Scientific American, 293(6), 92-99.

Saudino, K. J. ((2005). Behavioral genetics and child temperament. Journal of Developmental and Behavioral Pediatrics, 26(3), 214-223.

Sauter, R. C. (1993). Charter schools: A new breed of public schools. Retrieved from ERIC database. (ED361905).

Schellenberg, S. (1998, April 13-17). Does it matter where poor kids live? A look at concentrated poverty and achievement. Paper presented at the Annual Meeting of The American Educational Research Association, San Diego, CA. (ERIC Document Reproduction Service NO. ED 421573).

Schwartz, J. (1994, April). Low-level lead exposure and children's IQ: A meta-analysis and search for a threshold. Environmental Research, 65(1), 42-55.

Schweinhart, L. J., Montie, J., Xiang, Z., Barnett, W. S., Belfield, C. R., \& Nores, M. (2005). Lifetime Effects: The High/Scope Perry Preschool Study Through Age 40. Ypsilanti, MI: High/Scope Press. Chart accessed on Institute for Children, Poverty, and Homelessness website: $\underline{\text { http://www.icphusa.org/index.asp?page }=17 \& \text { asset }=140}$ 
Silva, E., \& Education, S. (2012). Off the clock: What more time can (and can't) do for school turnarounds. Education Sector Reports. Education Sector. Retrieved from http://www.educationsector.org/sites/default/files/publications/OffTheClockRELEASED.pdf

Simoes, E. A. (2003, November). Environmental and demographic risk factors for respiratory syncytial virus lower respiratory tract disease. Journal of Pediatrics, 143(5 Suppl.), S118126.

Smith, J. R., Brooks-Gunn, J., \& Klebanov, P. K. (1997). Consequences of living in poverty for young children's cognitive and verbal ability and early school achievement. In G. Duncan \& J. Brooks-Gunn (Eds.), Consequences of growing up poor (pp. 132-189). New York, NY: Russell Sage Foundation.

Smith, T. W., Gordon, B., Colby, S. A., \& Wang, J. W. (2005). An examination of the relationship between depth of student learning and national board certification status. Retrieved from http://www.nbpts.org/sites/default/files/documents/research/SmithGordonColbyWang_Rel ationshipofDepthofStudentLearningandNBCStatus.pdf

Soomro, K. A. (2015). Digital divide among Pakistani faculty regarding their information and communication technology (ICT) access (Order No. 3741896). Available from ProQuest Dissertations \& Theses Full Text. (1752219146). Retrieved from http://search.proquest.com/docview/1752219146?accountid=2837 
Sparks, S. D. (2014). 50 Years later, war on poverty yields mixed success. Education Week, 33(18), 1, 14-15. Retrieved from http://www.edweek.org/ew/articles/2014/01/22/18wopoverview_ep.h33.html?tkn=PUWFmGum300I7E4k8P77xqgdmo6\%2FwjVt\%2FmZF\&cm $\mathrm{p}=\mathrm{ENL}-\mathrm{EU}-\mathrm{NEWS} 1$

Spillane, J. P., Diamond, J.B., Burch, P., Hallett, T., Jita, L., \& Zoltners, J. (2002, November). Managing in the middle: School leaders and the enactment of accountability policy. Education Policy, 16(5), 371. DOI: 10.1177/089590402237311.

Spillane, J. P., Reiser, B. J., \& Reimer, T. (2002, Fall). Policy implementation and cognition: Reframing and refocusing implementation research. Review of Educational Research, 72(3), 387-431.

Stoppler, M. (2014). Developmental screening - Critical for every child. Retrieved from http://www.medicinenet.com/script/main/art.asp?articlekey=47688\&page $=2$

Stullich, S., Eisner, E., \& McCrary, J. (2007). National assessment of Title I: Final report (Report No. 2008-4012). Retrieved from Institute of Education Sciences at http://www.ies.ed.gov/ncee/pdf/20084012_rev.pdf

Szewcyk-Sokolowski, M, Bost, K. K., \& Wainwright, A. B. (2005, August). Attachment, temperament, and preschool children's peer acceptance. Social Development, 14, 379-397. DOI: 10.1111/j.1467-9507.2005.00307.x.

The National Commission on Excellence in Education. (1983). A nation at risk: The imperative for educational reform. Washington, DC: Author.

Tileston, D. W., \& Darling, S. (2008). Why culture counts. Bloomington, IN: Solution Tree 
Timar, T. B., \& Maxwell-Jolly. J. (Eds.). (2010). Narrowing the achievement gap: Perspectives and strategies for challenging times. Cambridge, MA: Harvard Education Press.

Tough, P. (2012). How children succeed. New York: Houghton Mifflin Harcourt Publishing.

United States Census Bureau. (2011). Income, poverty, and health insurance coverage in the United States: 2010. Retrieved from http://www.census.gov/newsroom/releases/archives/income_wealth/cb11-157.html\#tablea

United States Census Bureau. (2015). How the census bureau measures poverty. Retrieved from U.S. Census Bureau Website: http://www.census.gov/hhes/www/poverty/about/overview/measure.html

United States Census Bureau. (2016). Poverty thresholds. Retrieved from http://www.census.gov/data/tables/time-series/demo/income-poverty/historical-poverty$\underline{\text { thresholds.html }}$

United States Department of Agriculture. (2014). Food and nutrition service. Retrieved from the USDA website at http://www.fns.usda.gov/school-meals/child-nutrition-programs

United States Department of Education. (1983, April). A nation at risk. Retrieved from http://www2.ed.gov/pubs/NatAtRisk/risk.html

United States Department of Education. (2004a). Elementary and secondary education. Retrieved from http://www2.ed.gov/policy/elsec/leg/esea02/pg1.html

United States Department of Education. (2004b). Evaluation of the public charter school program: Final report. Retrieved from http://www2.ed.gov/rschstat/eval/choice/pcspfinal/execsum.html\#skipnav2. 
United States Department of Education. (2008). Laws and guidance. Retrieved from http://www2.ed.gov/policy/elsec/leg/esea02/beginning.html\#sec1

United States Department of Education. (2010). Evaluation of the DC opportunity scholarship program. National Center for Education Evaluation and Regional Assistance. Retrieved from http://ies.ed.gov/ncee/pubs/20104018/pdf/20104019.pdf

United States Department of Education. (2014). Program Description. Retrieved from the U.S. Department of Education website at http://www2.ed.gov/programs/titleiparta/index.html

United States Department of Education. (2016). Programs. Retrieved from http://www2.ed.gov/programs/teacherfellowship/index.html

United States Department of Health and Human Services. (2015). Poverty guidelines. Retrieved from

http://search.hhs.gov/search?q=poverty\&site=HHSgov\&entqr=3\&ud=1\&sort=date\%3AD \%3AL\%3Ad1\&output=xml_no_dtd\&ie=UTF-8\&oe=UTF$\underline{8 \& l r=l a n g \_ \text {en\&client=HHS\&proxystylesheet=HHS\&btnG=Search }}$

Vandervoort, L. G., Amrein-Beardsley, A. \& Berliner, D. C. (2004, September 8). National board certified teachers and their students' achievement. Education Policy Analysis Archives, 12 (46), 1-117.

Van Ijzendoorn, M. H., Vereijken, C .M. J. L., Bakermans-Kranenburg, M. J. \& RiksenWalreven, M .J. (2004). Assessing attachment security with the attachment q sort: Metaanalytic evidence for the validity of the observer AQS. Child Development, 75(4), 11881213. 
Wandell, B., Dougherty, R. F., Ben-Shacar, M., Marten, S., \& Tang, J. (2008). Training in the arts, reading, and brain functioning. In Asbury, C., \& Rich, B. (Eds.), Language, arts, and the brain (pp. 11-17). New York: Dana press. Retrieved from http://www.dana.org/uploadedFiles/News_and_Publications/Special_Publications/Learni ng,\%20Arts\%20and\%20the\%20Brain_ArtsAndCognition_Compl.pdf

Ware, G. (2015, January 19). Only one in ten education reforms analyzed for their impact: OECD. The Conversation. Retrieved from http://theconversation.com/only-one-in-ten$\underline{\text { education-reforms-analysed-for-their-impact-oecd-36461 }}$

Warwick, D. P., \& Lininger, C. A. (1975). The sample survey: Theory and practice. TX: McGraw Hill.

Web Center for Social Research Methods. (2006). Survey research. Retrieved from http://www.socialresearchmethods.net/kb/survey.php

Werner, E., \& Smith, R. (1982). Vulnerable but invincible: A longitudinal study of resilient children and youth. New York: Adams, Bannister and Cox.

West Virginia Department of Education. (2009, December). Closing the achievement gap report for $21^{\text {st }}$ century learners in West Virginia ( $3^{\text {rd }}$ ed.). Retrieved from ERIC database (ED508066).

West Virginia Department of Education. (2013). Memorandum. http://wvde.state.wv.us/oel/docs/school\%20screening\%20memo4.03.2013.pdf

West Virginia Department of Education. (2014a). 21 $1^{\text {st }}$ Century community learning centers. Retrieved from WVDE website: http://wvde.state.wv.us/21stcclc/programs.html 
West Virginia Department of Education. (2014b). 2013-2014 Title I schools. Retrieved from WVDE website: https://wvde.state.wv.us/titlei/titlei_schools.html

West Virginia Department of Education. (2014c). Welcome to West Virginia title I. Retrieved from the WVDE website: http://wvde.state.wv.us/titlei/

West Virginia Department of Education. (2014d, December 5) Hundreds of state schools showing improvements in academic proficiency and student growth. Retrieved from WVDE website: http://wvde.state.wv.us/news/3102/

West Virginia Department of Education. (2015a). School nutrition programs. Retrieved from WVDE website: https://wvde.state.wv.us/child-nutrition/school-nutrition-programs/

West Virginia Department of Education. (2015b, August 12). Preliminary statewide assessment results show positive achievement in literacy. Retrieved from WVDE website: http://wvde.state.wv.us/news/3208/

West Virginia Department of Education. (2016a). West Virginia district special education report. Retrieved from the WVDE website: http://wveis.k12.wv.us/nclb/OSEcf/data/replist1.cfm?cn=002\&rp=RPTCARD13\&pg=1

West Virginia Department of Education. (2016b). West Virginia feed to achieve. Retrieved from the WVDE website: https://wvde.state.wv.us/child-nutrition/feed-to-achieve/

White, K.R. (1982) The relation between socioeconomic status and academic achievement. Psychological Bulletin, 91, 461-481. http://dx.doi.org/10.1037/0033-2909.91.3.461

Will, M. (2016). Teachers feel their voices aren't heard in policy discussions, survey finds. Education Week. Retrieved from 
http://blogs.edweek.org/teachers/teaching_now/2016/05/teacher_voices_study.html?cmp =eml-enl-eu-news 2

Willis, G. B. (1999). Cognitive interviewing: A "how to" guide. Research Triangle Institute. 1999 Meeting of the American Statistical Association. Research Triangle Park, NC: Research Triangle Institute. Psychological Bulletin, 91(3), 461-481.

World Bank (2005). Better nutrition equals less poverty. Repositioning Nutrition as Central to Development: A Strategy for Large Scale Action. Retrieved from http://siteresources.worldbank.org/NUTRITION/Resources/2818461131636806329/NutritionStrategyBrochure.pdf 


\section{Appendix A}

\section{Policy Implementation Factors}

1. I have had the training that I need to implement this initiative.

2. I have had the materials that I need to implement this initiative.

3. I have had the necessary time to implement this initiative.

4. Teachers have had input into the design of this initiative.

5. I have had input into the implementation of this initiative.

6. I have had the opportunity to collaborate with my colleagues about this initiative.

7. This initiative is consistent with my beliefs about improving the academic achievement of my students.

8. This initiative is easy to implement.

9. This initiative does not require any major changes in my school/classroom.

10. I believe that this initiative has improved the academic achievement of the students in my classroom/school. 
Appendix B

Teacher Survey

Dear Participant:

This is a request for you to take part in a pilot test of an instrument to measure teachers' use and perceptions of initiatives recommended to improve the academic achievement of low socioeconomic children in West Virginia Title I schools. These policies and initiatives have a base in research.

Part 1: Demographics: Please answer the demographic questions. You may leave items blank.

Part 2: Initiatives: In this section you will check whether you use an initiative in your classroom or school. If yes, you will be presented with a list of questions such as, "I have had the training I need to successfully implement this initiative." Then, you may choose from strongly agree--4 to strongly disagree--1. You may also choose does not apply--0, if an item not apply.

Thank you.

Part I: Teacher Demographics: You may skip questions if you choose.

1. Programmatic configuration of your school.

Grades Pre-K-5 (1)

Grades 6-8 (2)

Grades 9-12 (3)

2. How many years of experience do you have teaching in West Virginia Title I schools?

0-5 (1)

6 6-10 (2)

O 11-15 (3)

16-20 (4)

More than 20 (5) 
3. What is your age?

- 20-30 (1)

O 31-40 (2)

O 41-50 (3)

51-(4)

4. What is your gender?

O Male (1)

O Female (2)

5. Do you have National Board Certification through the National Board for Professional Teaching Standards?

Y Yes (1)

No (2)

6. What is your highest education degree?

O Bachelor's (1)

Master's (2)

Doctorate (3)

7. In what county is your school located?

\section{Part 2: Initiatives}

In this section you will check whether you use an initiative in your classroom or school. If you choose yes, you will be presented with a list of questions such as "I have had the necessary training that I need to implement this initiative." You may choose from strongly agree-- 4 to strongly disagree--1. You may also choose does not apply if an item on the list does not apply. You may skip questions if you choose.

\section{Universal Preschool}

Universal Preschool (ages 3-5) is one strategy that has been used to give poor children the ability to enter first grade with the skills and language ability of their more affluent peers.

Quality preschool programs can have positive effects on high school graduation, achievement scores, future employment, and economic security and can reduce 
delinquency rates and special education placements (Frank Porter Graham Child Development Institute, 2014; Schweinhart, 2005). Karoly's study (2001) of Head Start 
showed that Whites and Latinos improved significantly in test scores and school attainment.

In West Virginia counties offer Universal Pre-K.

Do you use this initiative in your classroom/school?

Yes (1)

No (2)

Check all that apply for this initiative: 4--strongly agree; 3--agree; 2--disagree; 1--strongly disagree; and 0--does not apply 


\begin{tabular}{|c|c|c|c|c|c|}
\hline & $4(4)$ & $3(3)$ & $2(2)$ & $1(1)$ & $0(0)$ \\
\hline $\begin{array}{l}\text { I have had the } \\
\text { training that I } \\
\text { need to } \\
\text { implement this } \\
\text { initiative. (1) }\end{array}$ & 0 & O & 0 & 0 & 0 \\
\hline $\begin{array}{l}\text { I have had the } \\
\text { materials that I } \\
\text { need to } \\
\text { implement this } \\
\text { initiative. (2) }\end{array}$ & 0 & O & 0 & 0 & 0 \\
\hline $\begin{array}{l}\text { I have had the } \\
\text { necessary time to } \\
\text { implement this } \\
\text { initiative. (3) }\end{array}$ & 0 & O & 0 & 0 & 0 \\
\hline $\begin{array}{l}\text { Teachers have } \\
\text { had input into } \\
\text { the design of this } \\
\text { initiative. (4) }\end{array}$ & 0 & O & 0 & 0 & 0 \\
\hline $\begin{array}{l}\text { I have had input } \\
\text { into the } \\
\text { implementation } \\
\text { of this initiative. } \\
\text { (5) }\end{array}$ & 0 & O & 0 & 0 & 0 \\
\hline $\begin{array}{l}\text { I have had the } \\
\text { opportunity to } \\
\text { collaborate with } \\
\text { my colleagues } \\
\text { about this } \\
\text { initiative. (6) }\end{array}$ & 0 & 0 & 0 & 0 & 0 \\
\hline $\begin{array}{l}\text { This initiative is } \\
\text { consistent with } \\
\text { my beliefs about } \\
\text { improving the } \\
\text { academic } \\
\text { achievement of } \\
\text { my students. (7) }\end{array}$ & 0 & O & 0 & 0 & 0 \\
\hline $\begin{array}{l}\text { This initiative is } \\
\text { easy to } \\
\text { implement. (8) }\end{array}$ & 0 & O & 0 & 0 & 0 \\
\hline
\end{tabular}




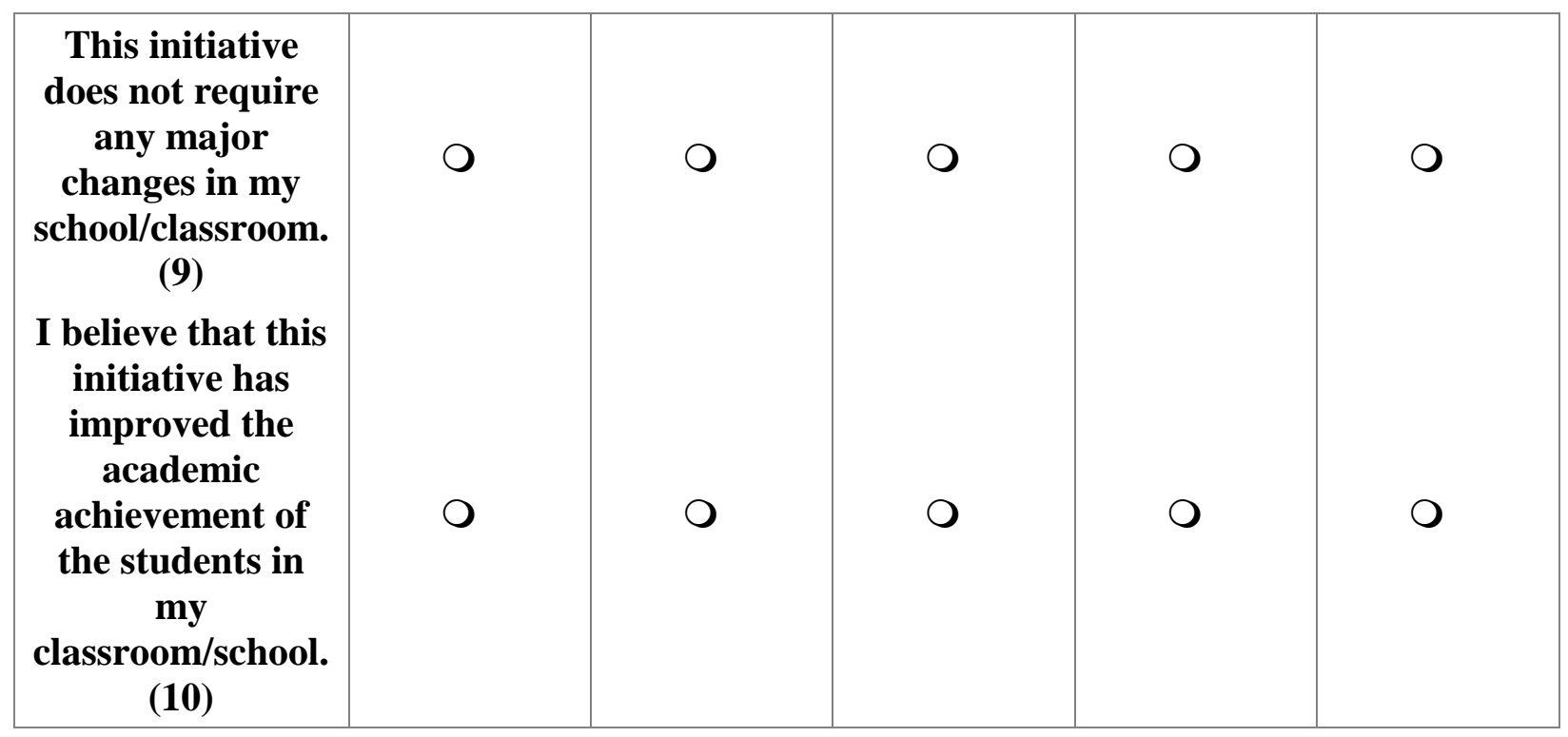

Comments

\section{After School Programs}

These programs can be run by school districts, nonprofit organizations, national organizations such as the Boys and Girls Club, or by for-profit entities. Programs may connect to the regular school day but can also be independent of the school.

A meta-analysis of 35 studies of after school programs in urban, suburban, and rural locations has been shown to have significant positive effects on reading and math achievement (Laurer et al., 2006).

In West Virginia Title I after school provides tutoring in reading and/or math at the end of the school day through the ESSA Title I program.

Do you use this initiative in your classroom/school?

Yes (1)

○ NO (2) 
Check all that apply for this initiative. 4--strongly agree; 3--agree; 2 --disagree; 1 --strongly disagree; and 0--does not apply 


\begin{tabular}{|c|c|c|c|c|c|}
\hline & $4(4)$ & 3 (3) & $2(2)$ & $1(1)$ & $0(0)$ \\
\hline $\begin{array}{l}\text { I have had the } \\
\text { training that I } \\
\text { need to } \\
\text { implement this } \\
\text { initiative. (1) }\end{array}$ & 0 & 0 & 0 & 0 & 0 \\
\hline $\begin{array}{l}\text { I have had the } \\
\text { materials that I } \\
\text { need to } \\
\text { implement this } \\
\text { initiative. (2) }\end{array}$ & 0 & 0 & 0 & 0 & 0 \\
\hline $\begin{array}{l}\text { I have had the } \\
\text { necessary time to } \\
\text { implement this } \\
\text { initiative. (3) }\end{array}$ & 0 & 0 & 0 & 0 & 0 \\
\hline $\begin{array}{l}\text { Teachers have } \\
\text { had input into } \\
\text { the design of this } \\
\text { initiative. (4) }\end{array}$ & 0 & 0 & 0 & 0 & 0 \\
\hline $\begin{array}{l}\text { I have had input } \\
\text { into the } \\
\text { implementation } \\
\text { of this initiative. } \\
\text { (5) }\end{array}$ & 0 & 0 & 0 & 0 & 0 \\
\hline $\begin{array}{l}\text { I have had the } \\
\text { opportunity to } \\
\text { collaborate with } \\
\text { my colleagues } \\
\text { about this } \\
\text { initiative. (6) }\end{array}$ & 0 & 0 & 0 & 0 & 0 \\
\hline $\begin{array}{l}\text { This initiative is } \\
\text { consistent with } \\
\text { my beliefs about } \\
\text { improving the } \\
\text { academic } \\
\text { achievement of } \\
\text { my students. ( } 7)\end{array}$ & 0 & 0 & 0 & 0 & 0 \\
\hline $\begin{array}{l}\text { This initiative is } \\
\text { easy to } \\
\text { implement. (8) }\end{array}$ & 0 & 0 & 0 & 0 & 0 \\
\hline
\end{tabular}




\begin{tabular}{|c|c|c|c|c|c|}
\hline $\begin{array}{c}\text { This initiative } \\
\text { does not require } \\
\text { major changes in } \\
\text { my } \\
\text { school/classroom. } \\
\text { (9) } \\
\text { I believe this } \\
\text { initiative has } \\
\text { improved the } \\
\text { academic } \\
\text { achievement of } \\
\text { the students in } \\
\text { my } \\
\text { classroom/school. } \\
(10)\end{array}$ & 0 & 0 & 0 & 0 & 0 \\
\hline
\end{tabular}

\section{Comments}

In West Virginia Twenty-first Century Community Learning Centers are another after school program. They provide a minimum of 36 weeks of 12 hours of academic and enrichment activities before and after school and in the summer.

Do you use this initiative in your classroom/school?

Yes (1)

No (2) 
Check all that apply for this initiative. 4--strongly agree; 3--agree; 2 --disagree; 1 --strongly disagree; and 0--does not apply 


\begin{tabular}{|c|c|c|c|c|c|}
\hline & $4(4)$ & $3(3)$ & $2(2)$ & $1(1)$ & $0(0)$ \\
\hline $\begin{array}{l}\text { I have had the } \\
\text { training that I } \\
\text { need to } \\
\text { implement this } \\
\text { initiative. (1) }\end{array}$ & 0 & O & 0 & 0 & 0 \\
\hline $\begin{array}{l}\text { I have had the } \\
\text { materials that I } \\
\text { need to } \\
\text { implement this } \\
\text { initiative. (2) }\end{array}$ & 0 & O & 0 & 0 & 0 \\
\hline $\begin{array}{l}\text { I have had the } \\
\text { necessary time to } \\
\text { implement this } \\
\text { initiative. (3) }\end{array}$ & O & O & 0 & 0 & 0 \\
\hline $\begin{array}{l}\text { Teachers have } \\
\text { had input into } \\
\text { the design of this } \\
\text { initiative. (4) }\end{array}$ & 0 & O & 0 & 0 & 0 \\
\hline $\begin{array}{l}\text { I believe that } \\
\text { teachers have } \\
\text { had input into } \\
\text { the design of this } \\
\text { initiative. (5) }\end{array}$ & O & O & 0 & 0 & 0 \\
\hline $\begin{array}{l}\text { I have had the } \\
\text { opportunity to } \\
\text { collaborate with } \\
\text { my colleagues } \\
\text { about this } \\
\text { initiative. (6) }\end{array}$ & O & 0 & 0 & 0 & 0 \\
\hline $\begin{array}{l}\text { This initiative is } \\
\text { consistent with } \\
\text { my beliefs about } \\
\text { improving the } \\
\text { academic } \\
\text { achievement of } \\
\text { my students. (7) }\end{array}$ & 0 & O & 0 & 0 & 0 \\
\hline $\begin{array}{l}\text { This initiative is } \\
\text { easy to } \\
\text { implement. (8) }\end{array}$ & 0 & O & 0 & 0 & 0 \\
\hline
\end{tabular}




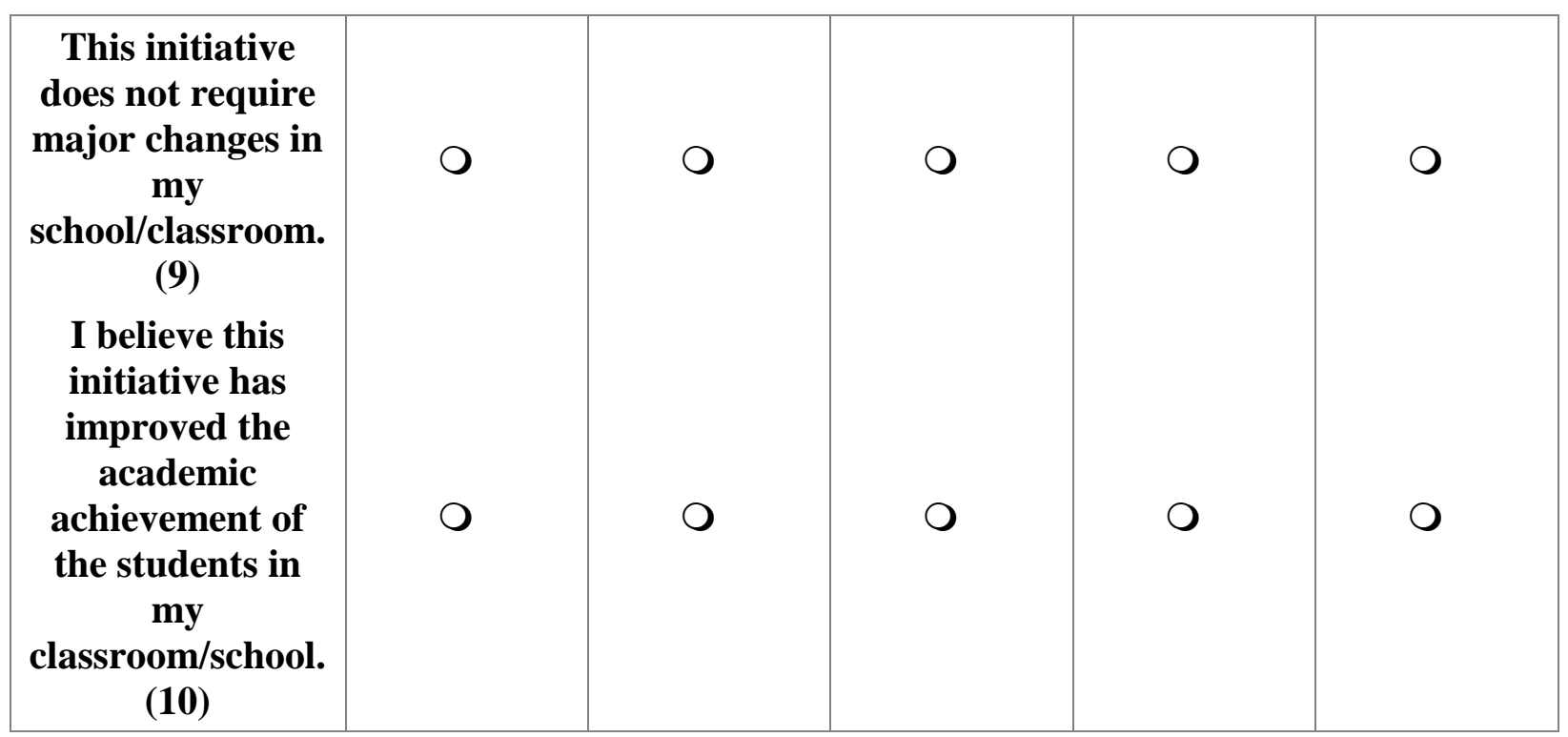

\section{Comments}

\section{Adding Minutes/Hours/Days to School Calendar}

In these district-run extended day or expanded learning time programs, the regular school day and/or year is extended, providing more time for the district to provide instruction.

Research is mixed about the results of adding minutes and/or days, but it is clear that it is the quality of extra time and not the length that is important (Silva, 2012).

In West Virginia extra time can be provided through Title I Summer School. 
Do you use this initiative in your classroom/school?

Yes (1)

No (2)

Check all that apply for this initiative. 4--strongly agree; 3--agree; 2--disagree; 1--strongly disagree; and 0--does not apply 


\begin{tabular}{|c|c|c|c|c|c|}
\hline & $4(4)$ & 3 (3) & $2(2)$ & $1(1)$ & $0(0)$ \\
\hline $\begin{array}{l}\text { I have had the } \\
\text { training that I } \\
\text { need to } \\
\text { implement this } \\
\text { initiative. (1) }\end{array}$ & 0 & 0 & 0 & 0 & 0 \\
\hline $\begin{array}{l}\text { I have had the } \\
\text { materials that I } \\
\text { need to } \\
\text { implement this } \\
\text { initiative. }(2)\end{array}$ & 0 & 0 & 0 & 0 & 0 \\
\hline $\begin{array}{l}\text { I have had the } \\
\text { necessary time to } \\
\text { implement this } \\
\text { initiative. (3) }\end{array}$ & 0 & 0 & 0 & 0 & 0 \\
\hline $\begin{array}{l}\text { Teachers have } \\
\text { had input into } \\
\text { the design of this } \\
\text { initiative. (4) }\end{array}$ & 0 & 0 & 0 & 0 & 0 \\
\hline $\begin{array}{l}\text { I have had input } \\
\text { into the } \\
\text { implementation } \\
\text { of this initiative. } \\
\text { (5) }\end{array}$ & 0 & 0 & 0 & 0 & 0 \\
\hline $\begin{array}{l}\text { I have had the } \\
\text { opportunity to } \\
\text { collaborate with } \\
\text { my colleagues } \\
\text { about this } \\
\text { initiative. (6) }\end{array}$ & 0 & 0 & 0 & 0 & 0 \\
\hline $\begin{array}{l}\text { This initiative is } \\
\text { consistent with } \\
\text { my beliefs about } \\
\text { improving the } \\
\text { academic } \\
\text { achievement of } \\
\text { my students. (7) }\end{array}$ & 0 & 0 & 0 & 0 & 0 \\
\hline $\begin{array}{l}\text { This initiative is } \\
\text { easy to } \\
\text { implement. (8) }\end{array}$ & 0 & 0 & 0 & 0 & 0 \\
\hline
\end{tabular}




\begin{tabular}{|c|c|c|c|c|c|}
\hline $\begin{array}{c}\text { This initiative } \\
\text { does not require } \\
\text { major changes in } \\
\text { my } \\
\text { classroom/school. } \\
(9) \\
\text { I believe this } \\
\text { initiative has } \\
\text { improved the } \\
\text { academic } \\
\text { achievement of } \\
\text { the students in } \\
\text { my } \\
\text { classroom/school. } \\
(10)\end{array}$ & 0 & 0 & 0 & 0 & 0 \\
\hline
\end{tabular}

\section{Comments}

\section{Teachers' High Expectations.}

Teachers' beliefs and high expectations may directly influence students' academic experiences. Students perform better when teachers believe they are competent (Johns, Schmader, \& Martens, 2005; Rosenthal \& Jacobsen, 1992). Students who believed that their intelligence could be developed (growth mindset) were more motivated and outperformed those who believed their intelligence was fixed (Dweck, 2015).

Do you use this initiative in your classroom/school?

O Yes (1)

O No (2) 
Check all that apply for this initiative. 4--strongly agree; 3--agree; 2 --disagree; 1 --strongly disagree; and 0--does not apply 


\begin{tabular}{|c|c|c|c|c|c|}
\hline & $4(4)$ & $3(3)$ & $2(2)$ & $1(1)$ & $0(0)$ \\
\hline $\begin{array}{l}\text { I have had the } \\
\text { training that I } \\
\text { need to } \\
\text { implement this } \\
\text { initiative. (1) }\end{array}$ & 0 & 0 & 0 & 0 & 0 \\
\hline $\begin{array}{l}\text { I have had the } \\
\text { materials that I } \\
\text { need to } \\
\text { implement this } \\
\text { initiative. }(2)\end{array}$ & 0 & 0 & 0 & 0 & 0 \\
\hline $\begin{array}{l}\text { I have had the } \\
\text { necessary time to } \\
\text { implement this } \\
\text { initiative. (3) }\end{array}$ & 0 & $\bigcirc$ & 0 & 0 & 0 \\
\hline $\begin{array}{l}\text { Teachers have } \\
\text { had input into } \\
\text { the design of this } \\
\text { initiative. (4) }\end{array}$ & 0 & 0 & 0 & 0 & 0 \\
\hline $\begin{array}{l}\text { I have had input } \\
\text { into the } \\
\text { implementation } \\
\text { of this initiative. } \\
\text { (5) }\end{array}$ & 0 & 0 & 0 & 0 & 0 \\
\hline $\begin{array}{l}\text { I have had the } \\
\text { opportunity to } \\
\text { collaborate with } \\
\text { my colleagues } \\
\text { about this } \\
\text { initiative (6) }\end{array}$ & 0 & 0 & 0 & 0 & 0 \\
\hline $\begin{array}{l}\text { This initiative is } \\
\text { consistent with } \\
\text { my beliefs about } \\
\text { improving the } \\
\text { academic } \\
\text { achievement of } \\
\text { my students. (7) }\end{array}$ & 0 & 0 & 0 & 0 & 0 \\
\hline $\begin{array}{l}\text { This initiative is } \\
\text { easy to } \\
\text { implement. (8) }\end{array}$ & 0 & 0 & 0 & 0 & 0 \\
\hline
\end{tabular}




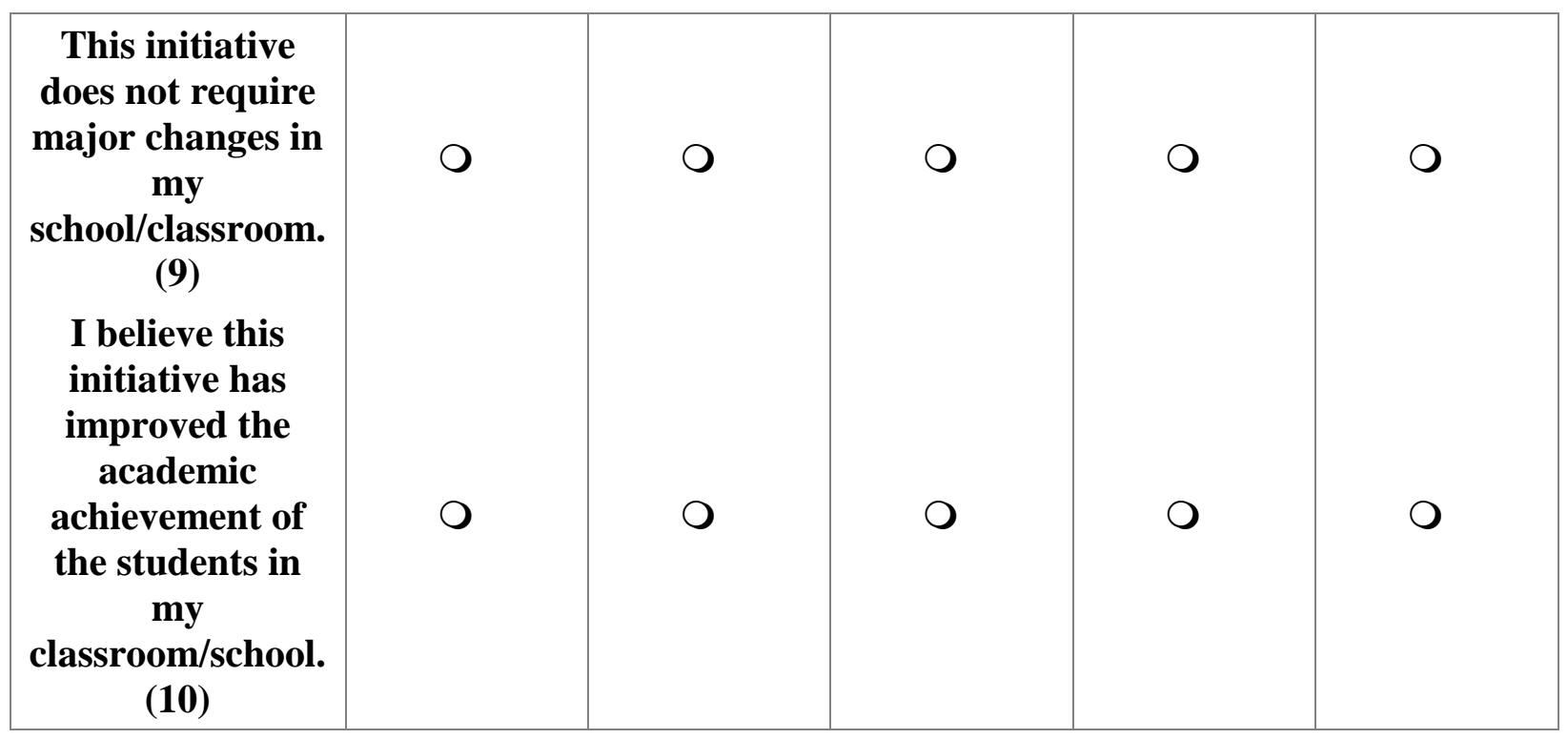

Teaching Resilience and Coping Skills

This includes teaching appropriate responses, providing students with a locus of control, increasing students' efficacy, recognizing and respecting relationships, incorporating students' different cultures and backgrounds, and teaching planning and organization and cause and effect (Tileston \& Darling, 2008).

In summarizing their 35-year study of resiliency in childhood, Werner and Smith found that resilient students "succeeded in school, managed home and social life well, and set realistic educational and vocational goals and expec-tations for themselves" $(1982$, p. 11).

In West Virginia the Responsible Students through School-Wide Behavior provides students with appropriate behavior skills.

Do you use this initiative in your classroom/school?

O Yes (1)

O No (2) 
Check all that apply for this initiative. 4--strongly agree; 3 --agree; 2 -disagree; 1 --strongly disagree; and 0--does not apply 


\begin{tabular}{|c|c|c|c|c|c|}
\hline & $4(4)$ & $3(3)$ & $2(2)$ & $1(1)$ & $0(0)$ \\
\hline $\begin{array}{l}\text { I have had the } \\
\text { training that I } \\
\text { need to } \\
\text { implement this } \\
\text { initiative. (1) }\end{array}$ & 0 & O & 0 & 0 & 0 \\
\hline $\begin{array}{l}\text { I have had the } \\
\text { materials that I } \\
\text { need to } \\
\text { implement this } \\
\text { initiative. (2) }\end{array}$ & 0 & O & 0 & 0 & 0 \\
\hline $\begin{array}{l}\text { I have had the } \\
\text { necessary time to } \\
\text { implement this } \\
\text { initiative. (3) }\end{array}$ & 0 & O & 0 & 0 & 0 \\
\hline $\begin{array}{l}\text { Teachers have } \\
\text { had input into } \\
\text { the design of this } \\
\text { initiative. (4) }\end{array}$ & 0 & O & 0 & 0 & 0 \\
\hline $\begin{array}{l}\text { I have had input } \\
\text { into the } \\
\text { implementation } \\
\text { of this initiative. } \\
\text { (5) }\end{array}$ & 0 & O & 0 & 0 & 0 \\
\hline $\begin{array}{l}\text { I have had the } \\
\text { opportunity to } \\
\text { collaborate with } \\
\text { my colleagues } \\
\text { about this } \\
\text { initiative. (6) }\end{array}$ & 0 & 0 & 0 & 0 & 0 \\
\hline $\begin{array}{l}\text { This initiative is } \\
\text { consistent with } \\
\text { my beliefs about } \\
\text { improving the } \\
\text { academic } \\
\text { achievement of } \\
\text { my students. (7) }\end{array}$ & 0 & O & 0 & 0 & 0 \\
\hline $\begin{array}{l}\text { This initiative is } \\
\text { easy to } \\
\text { implement. (8) }\end{array}$ & 0 & O & 0 & 0 & 0 \\
\hline
\end{tabular}




\begin{tabular}{|c|c|c|c|c|c|}
\hline $\begin{array}{c}\text { This initiative } \\
\text { does not require } \\
\text { major changes in } \\
\text { my } \\
\text { school/classroom. } \\
\text { (9) } \\
\text { I believe this } \\
\text { initiative has } \\
\text { improved the } \\
\text { academic } \\
\text { achievement of } \\
\text { the students in } \\
\text { my } \\
\text { classroom/school. } \\
(10)\end{array}$ & O & 0 & 0 & 0 & 0 \\
\hline
\end{tabular}

\section{Comments}

Increased Time in Physical Activity

Increasing the amount of time in physical education classes, providing physical activities in the classroom, and providing recess time have been shown to have positive effects on cognitive skills and attitudes, academic behavior, and academic achievement (Hellmich, 2010).

In West Virginia Policy 2520.6 contains the content standards for a rigorous physical education program including the Fitnessgram.

Do you use this initiative in your classroom/school?

O Yes (1)

O No (2) 
Check all that apply for this initiative. 4--strongly agree; 3--agree; 2 --disagree; 1 --strongly disagree; and 0--does not apply 


\begin{tabular}{|c|c|c|c|c|c|}
\hline & $4(4)$ & $3(3)$ & $2(2)$ & $1(1)$ & $0(0)$ \\
\hline $\begin{array}{l}\text { I have had the } \\
\text { training that I } \\
\text { need to } \\
\text { implement this } \\
\text { initiative. (1) }\end{array}$ & 0 & O & 0 & 0 & 0 \\
\hline $\begin{array}{l}\text { I have had the } \\
\text { materials that I } \\
\text { need to } \\
\text { implement this } \\
\text { initiative. (2) }\end{array}$ & 0 & O & 0 & 0 & 0 \\
\hline $\begin{array}{l}\text { I have had the } \\
\text { necessary time to } \\
\text { implement this } \\
\text { initiative. (3) }\end{array}$ & 0 & O & 0 & 0 & 0 \\
\hline $\begin{array}{l}\text { Teachers have } \\
\text { had input into } \\
\text { the design of this } \\
\text { initiative. (4) }\end{array}$ & 0 & O & 0 & 0 & 0 \\
\hline $\begin{array}{l}\text { I have had input } \\
\text { into the } \\
\text { implementation } \\
\text { of this initiative. } \\
\text { (5) }\end{array}$ & 0 & O & 0 & 0 & 0 \\
\hline $\begin{array}{l}\text { I have had the } \\
\text { opportunity to } \\
\text { collaborate with } \\
\text { my colleagues } \\
\text { about this } \\
\text { initiative. (6) }\end{array}$ & 0 & 0 & 0 & 0 & 0 \\
\hline $\begin{array}{l}\text { This initiative is } \\
\text { consistent with } \\
\text { my beliefs about } \\
\text { improving the } \\
\text { academic } \\
\text { achievement of } \\
\text { my students. (7) }\end{array}$ & 0 & O & 0 & 0 & 0 \\
\hline $\begin{array}{l}\text { This initiative is } \\
\text { easy to } \\
\text { implement. (8) }\end{array}$ & 0 & O & 0 & 0 & 0 \\
\hline
\end{tabular}




\begin{tabular}{|c|c|c|c|c|c|}
\hline $\begin{array}{c}\text { This initiative } \\
\text { does not require } \\
\text { major changes in } \\
\text { my } \\
\text { school/classroom. } \\
\text { (9) } \\
\text { I believe this } \\
\text { initiative has } \\
\text { improved the } \\
\text { academic } \\
\text { achievement of } \\
\text { the students in } \\
\text { my } \\
\text { classroom/school. } \\
(10)\end{array}$ & 0 & 0 & 0 & 0 & 0 \\
\hline
\end{tabular}

\section{Comments}

\section{Arts Education.}

Arts education is used for a range of desirable outcomes including math ability, memory skills, and reading.

Training in music has been shown to improve cognitive memory by making strategic changes in the brain where retrievable memories are maintained (Jonides, 2008). Education in visual arts also has been shown to improve math calculation (Wandell et al., 2008).

Do you use this initiative in your classroom/school?

O Yes (1)

O No (2) 
Check all that apply for this initiative. 4--strongly agree; 3--agree; 2 --disagree; 1 --strongly disagree; and 0--does not apply 


\begin{tabular}{|c|c|c|c|c|c|}
\hline & $4(4)$ & $3(3)$ & $2(2)$ & $1(1)$ & $0(0)$ \\
\hline $\begin{array}{l}\text { I have had the } \\
\text { training that I } \\
\text { need to } \\
\text { implement this } \\
\text { initiative. (1) }\end{array}$ & 0 & O & 0 & 0 & 0 \\
\hline $\begin{array}{l}\text { I have had the } \\
\text { materials that I } \\
\text { need to } \\
\text { implement this } \\
\text { initiative. (2) }\end{array}$ & 0 & O & 0 & 0 & 0 \\
\hline $\begin{array}{l}\text { I have had the } \\
\text { necessary time to } \\
\text { implement this } \\
\text { initiative. (3) }\end{array}$ & 0 & O & 0 & 0 & 0 \\
\hline $\begin{array}{l}\text { Teachers have } \\
\text { had input into } \\
\text { the design of this } \\
\text { initiative. (4) }\end{array}$ & 0 & O & 0 & 0 & 0 \\
\hline $\begin{array}{l}\text { I have had input } \\
\text { into the } \\
\text { implementation } \\
\text { of this initiative. } \\
\text { (5) }\end{array}$ & 0 & O & 0 & 0 & 0 \\
\hline $\begin{array}{l}\text { I have had the } \\
\text { opportunity to } \\
\text { collaborate with } \\
\text { my colleagues } \\
\text { about this } \\
\text { initiative. (6) }\end{array}$ & 0 & 0 & 0 & 0 & 0 \\
\hline $\begin{array}{l}\text { This initiative is } \\
\text { consistent with } \\
\text { my beliefs about } \\
\text { improving the } \\
\text { academic } \\
\text { achievement of } \\
\text { my students. (7) }\end{array}$ & 0 & O & 0 & 0 & 0 \\
\hline $\begin{array}{l}\text { This initiative is } \\
\text { easy to } \\
\text { implement. (8) }\end{array}$ & 0 & O & 0 & 0 & 0 \\
\hline
\end{tabular}




\begin{tabular}{|c|c|c|c|c|c|}
\hline $\begin{array}{c}\text { This initiative } \\
\text { does not require } \\
\text { major changes in } \\
\text { my } \\
\text { school/classroom. } \\
\text { (9) } \\
\text { I believe this } \\
\text { initiative has } \\
\text { improved the } \\
\text { academic } \\
\text { achievement of } \\
\text { the students in } \\
\text { my } \\
\text { classroom/school. } \\
(10)\end{array}$ & 0 & 0 & 0 & 0 & 0 \\
\hline
\end{tabular}

High Stakes Summative Testing

High stakes summative standardized testing is linked to state and national standards and student and teacher evaluation. These tests are typically standardized and are marketed by testing companies. Although they can be used in a formative way, these tests are usually summative and used to compare groups, students, and teachers.

In West Virginia the West Virginia General Summative Assessment is administered each spring. 
Do you use this initiative in your classroom/school?

Yes (1)

No (2)

Check all that apply for this initiative. 4--strongly agree; 3--agree; 2--disagree; 1--strongly disagree; and 0--does not apply 


\begin{tabular}{|c|c|c|c|c|c|}
\hline & $4(4)$ & 3 (3) & $2(2)$ & $1(1)$ & $0(0)$ \\
\hline $\begin{array}{l}\text { I have had the } \\
\text { training that I } \\
\text { need to } \\
\text { implement this } \\
\text { initiative. (1) }\end{array}$ & 0 & 0 & 0 & 0 & 0 \\
\hline $\begin{array}{l}\text { I have had the } \\
\text { materials that I } \\
\text { need to } \\
\text { implement this } \\
\text { initiative. (2) }\end{array}$ & 0 & 0 & 0 & 0 & 0 \\
\hline $\begin{array}{l}\text { I have had the } \\
\text { necessary time to } \\
\text { implement this } \\
\text { initiative. (3) }\end{array}$ & $\bigcirc$ & 0 & 0 & 0 & 0 \\
\hline $\begin{array}{l}\text { Teachers have } \\
\text { had input into } \\
\text { the design of this } \\
\text { initiative. (4) }\end{array}$ & 0 & 0 & $\bigcirc$ & 0 & 0 \\
\hline $\begin{array}{l}\text { I have had input } \\
\text { into the } \\
\text { implementation } \\
\text { of this initiative. } \\
\text { (5) }\end{array}$ & 0 & 0 & 0 & 0 & 0 \\
\hline $\begin{array}{l}\text { I have had the } \\
\text { opportunity to } \\
\text { collaborate with } \\
\text { my colleagues } \\
\text { about this } \\
\text { initiative. (6) }\end{array}$ & 0 & 0 & 0 & 0 & 0 \\
\hline $\begin{array}{l}\text { This initiative is } \\
\text { consistent with } \\
\text { my beliefs about } \\
\text { improving the } \\
\text { academic } \\
\text { achievement of } \\
\text { my students. (7) }\end{array}$ & 0 & 0 & 0 & 0 & 0 \\
\hline $\begin{array}{l}\text { This initiative is } \\
\text { easy to } \\
\text { implement. (8) }\end{array}$ & 0 & 0 & 0 & 0 & 0 \\
\hline
\end{tabular}




\begin{tabular}{|c|c|c|c|c|c|}
\hline $\begin{array}{c}\text { This initiative } \\
\text { does not require } \\
\text { major changes in } \\
\text { my } \\
\text { school/classroom. } \\
\text { (9) } \\
\text { I believe this } \\
\text { initiative has } \\
\text { improved the } \\
\text { academic } \\
\text { achievement of } \\
\text { the students in } \\
\text { my } \\
\text { classroom/school. } \\
(10)\end{array}$ & 0 & 0 & 0 & 0 & 0 \\
\hline
\end{tabular}

\section{Comments}

Formative Assessment

Formative Performance Assessment is a type of formative testing used to diagnose problems or check progress.

A New York City model in which teachers used formative performance assessment for evaluation showed better long term effects than summative assessment for students including fewer dropouts and more students attending and finishing college (New York Performance Standards Consortium, 2014). Studies have shown higher student achievement with the use of formative assessment (Carpenter, 1991; Fuchs, 1989).

Do you use this initiative in your classroom/school?

Yes (1)

No (2) 
Check all that apply for this initiative. 4--strongly agree; 3--agree; 2 --disagree; 1 --strongly disagree; and 0--does not apply 


\begin{tabular}{|c|c|c|c|c|c|}
\hline & $4(4)$ & $3(3)$ & $2(2)$ & $1(1)$ & $0(0)$ \\
\hline $\begin{array}{l}\text { I have had the } \\
\text { training that I } \\
\text { need to } \\
\text { implement this } \\
\text { initiative. (1) }\end{array}$ & 0 & 0 & 0 & 0 & 0 \\
\hline $\begin{array}{l}\text { I have had the } \\
\text { materials that I } \\
\text { need to } \\
\text { implement this } \\
\text { initiative. (2) }\end{array}$ & 0 & 0 & 0 & 0 & 0 \\
\hline $\begin{array}{l}\text { I have had the } \\
\text { necessary time to } \\
\text { implement this } \\
\text { initiative. (3) }\end{array}$ & 0 & 0 & 0 & 0 & 0 \\
\hline $\begin{array}{l}\text { Teachers have } \\
\text { had input into } \\
\text { the design of this } \\
\text { initiative. (4) }\end{array}$ & 0 & 0 & 0 & 0 & 0 \\
\hline $\begin{array}{l}\text { I have had input } \\
\text { into the } \\
\text { implementation } \\
\text { of this initiative. } \\
\text { (5) }\end{array}$ & 0 & 0 & 0 & 0 & 0 \\
\hline $\begin{array}{l}\text { I have had the } \\
\text { opportunity to } \\
\text { collaborate with } \\
\text { my colleagues } \\
\text { about this } \\
\text { initiative. (6) }\end{array}$ & 0 & 0 & 0 & 0 & 0 \\
\hline $\begin{array}{l}\text { This initiative is } \\
\text { consistent with } \\
\text { my beliefs about } \\
\text { improving the } \\
\text { academic } \\
\text { achievement of } \\
\text { my students. (7) }\end{array}$ & 0 & 0 & 0 & 0 & 0 \\
\hline $\begin{array}{l}\text { This initiative is } \\
\text { easy to } \\
\text { implement. (8) }\end{array}$ & 0 & 0 & 0 & 0 & 0 \\
\hline
\end{tabular}




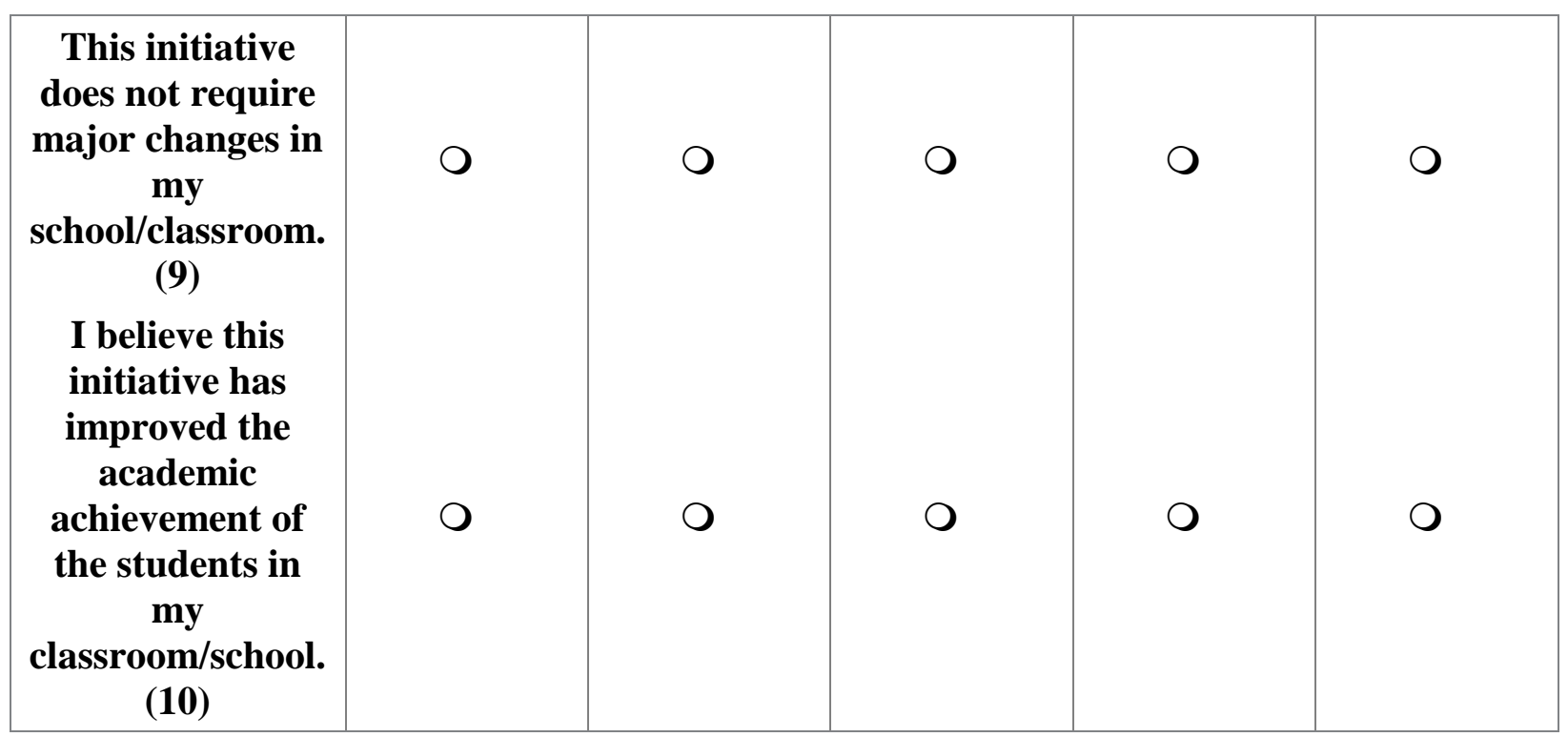

\section{Comments}

Response to Intervention (RTI)

RTI is a three-tiered approach to helping struggling readers through a series of interventions based on research proven programs.

In a study by the Society for Research on Educational Effectiveness, a leveled literacy intervention program positively impacted student achievement especially for disadvantaged youth (Ransford-Kaldon et al., 2011). In a 2010 study of 83 students who used RTI, 82\% achieved grade level benchmarks using intensive tier 2 interventions (Maskill, 2012).

In West Virginia RTI, renamed in 2010-2011 to Support for Personalized Learning (SPL), is used in Title I schools in grades K-3.

Do you use this initiative in your classroom/school?

Yes (1)

No (2) 
Check all that apply for this initiative. 4--strongly agree; 3--agree; 2 --disagree; 1 --strongly disagree; and 0--does not apply 


\begin{tabular}{|c|c|c|c|c|c|}
\hline & $4(4)$ & $3(3)$ & $2(2)$ & $1(1)$ & $0(0)$ \\
\hline $\begin{array}{l}\text { I have had the } \\
\text { training that I } \\
\text { need to } \\
\text { implement this } \\
\text { initiative. (1) }\end{array}$ & 0 & O & 0 & 0 & 0 \\
\hline $\begin{array}{l}\text { I have had the } \\
\text { materials that I } \\
\text { need to } \\
\text { implement this } \\
\text { initiative. (2) }\end{array}$ & 0 & O & 0 & 0 & 0 \\
\hline $\begin{array}{l}\text { I have had the } \\
\text { necessary time to } \\
\text { implement this } \\
\text { initiative. (3) }\end{array}$ & 0 & O & 0 & 0 & 0 \\
\hline $\begin{array}{l}\text { Teachers have } \\
\text { had input into } \\
\text { the design of this } \\
\text { initiative. (4) }\end{array}$ & 0 & O & 0 & 0 & 0 \\
\hline $\begin{array}{l}\text { I have had input } \\
\text { into the } \\
\text { implementation } \\
\text { of this initiative. } \\
\text { (5) }\end{array}$ & 0 & O & 0 & 0 & 0 \\
\hline $\begin{array}{l}\text { I have had the } \\
\text { opportunity to } \\
\text { collaborate with } \\
\text { my colleagues } \\
\text { about this } \\
\text { initiative. (6) }\end{array}$ & 0 & 0 & 0 & 0 & 0 \\
\hline $\begin{array}{l}\text { This initiative is } \\
\text { consistent with } \\
\text { my beliefs about } \\
\text { improving the } \\
\text { academic } \\
\text { achievement of } \\
\text { my students. (7) }\end{array}$ & 0 & O & 0 & 0 & 0 \\
\hline $\begin{array}{l}\text { This initiative is } \\
\text { easy to } \\
\text { implement. (8) }\end{array}$ & 0 & O & 0 & 0 & 0 \\
\hline
\end{tabular}




\begin{tabular}{|c|c|c|c|c|c|}
\hline $\begin{array}{c}\text { This initiative } \\
\text { does not require } \\
\text { major changes in } \\
\text { my } \\
\text { school/classroom. } \\
\text { (9) } \\
\text { I believe this } \\
\text { initiative has } \\
\text { improved the } \\
\text { academic } \\
\text { achievement of } \\
\text { the students in } \\
\text { my } \\
\text { classroom/school. } \\
(10)\end{array}$ & 0 & 0 & 0 & 0 & 0 \\
\hline
\end{tabular}

\section{Comments}

\section{Differentiated Instruction}

In practice, it involves "...offering several different learning experiences in response to students' varied needs” (Ravitch, 2007, p. 75).

Although there is limited research on the effects of differentiated instruction, most studies show a positive correlation with achievement and attitude (Rock et al., 2008).

In West Virginia the Middle School Differentiated Instruction Project included 20 special education teachers and 27 general education teachers who then provided on-going training and professional development for teachers across the state.

Do you use this initiative in your classroom/school?

O Yes (1)

No (2) 
Check all that apply for this initiative. 4--strongly agree; 3--agree; 2 --disagree; 1 --strongly disagree; and 0--does not apply 


\begin{tabular}{|c|c|c|c|c|c|}
\hline & $4(4)$ & $3(3)$ & $2(2)$ & $1(1)$ & $0(0)$ \\
\hline $\begin{array}{l}\text { I have had the } \\
\text { training that I } \\
\text { need to } \\
\text { implement this } \\
\text { initiative. (1) }\end{array}$ & 0 & 0 & 0 & 0 & 0 \\
\hline $\begin{array}{l}\text { I have had the } \\
\text { materials that I } \\
\text { need to } \\
\text { implement this } \\
\text { initiative. }(2)\end{array}$ & 0 & 0 & 0 & 0 & 0 \\
\hline $\begin{array}{l}\text { I have had the } \\
\text { necessary time to } \\
\text { implement this } \\
\text { initiative. (3) }\end{array}$ & 0 & $\bigcirc$ & 0 & 0 & 0 \\
\hline $\begin{array}{l}\text { Teachers have } \\
\text { had input into } \\
\text { the design of this } \\
\text { initiative. (4) }\end{array}$ & 0 & 0 & 0 & 0 & 0 \\
\hline $\begin{array}{l}\text { I have had input } \\
\text { into the } \\
\text { implementation } \\
\text { of this initiative. } \\
\text { (5) }\end{array}$ & 0 & 0 & 0 & 0 & 0 \\
\hline $\begin{array}{l}\text { I have had the } \\
\text { opportunity to } \\
\text { collaborate with } \\
\text { my colleagues } \\
\text { about this } \\
\text { initiative. (6) }\end{array}$ & 0 & 0 & 0 & 0 & 0 \\
\hline $\begin{array}{l}\text { This initiative is } \\
\text { consistent with } \\
\text { my beliefs about } \\
\text { improving the } \\
\text { academic } \\
\text { achievement of } \\
\text { my students. (7) }\end{array}$ & 0 & 0 & 0 & 0 & 0 \\
\hline $\begin{array}{l}\text { This initiative is } \\
\text { easy to } \\
\text { implement. (8) }\end{array}$ & 0 & 0 & 0 & 0 & 0 \\
\hline
\end{tabular}




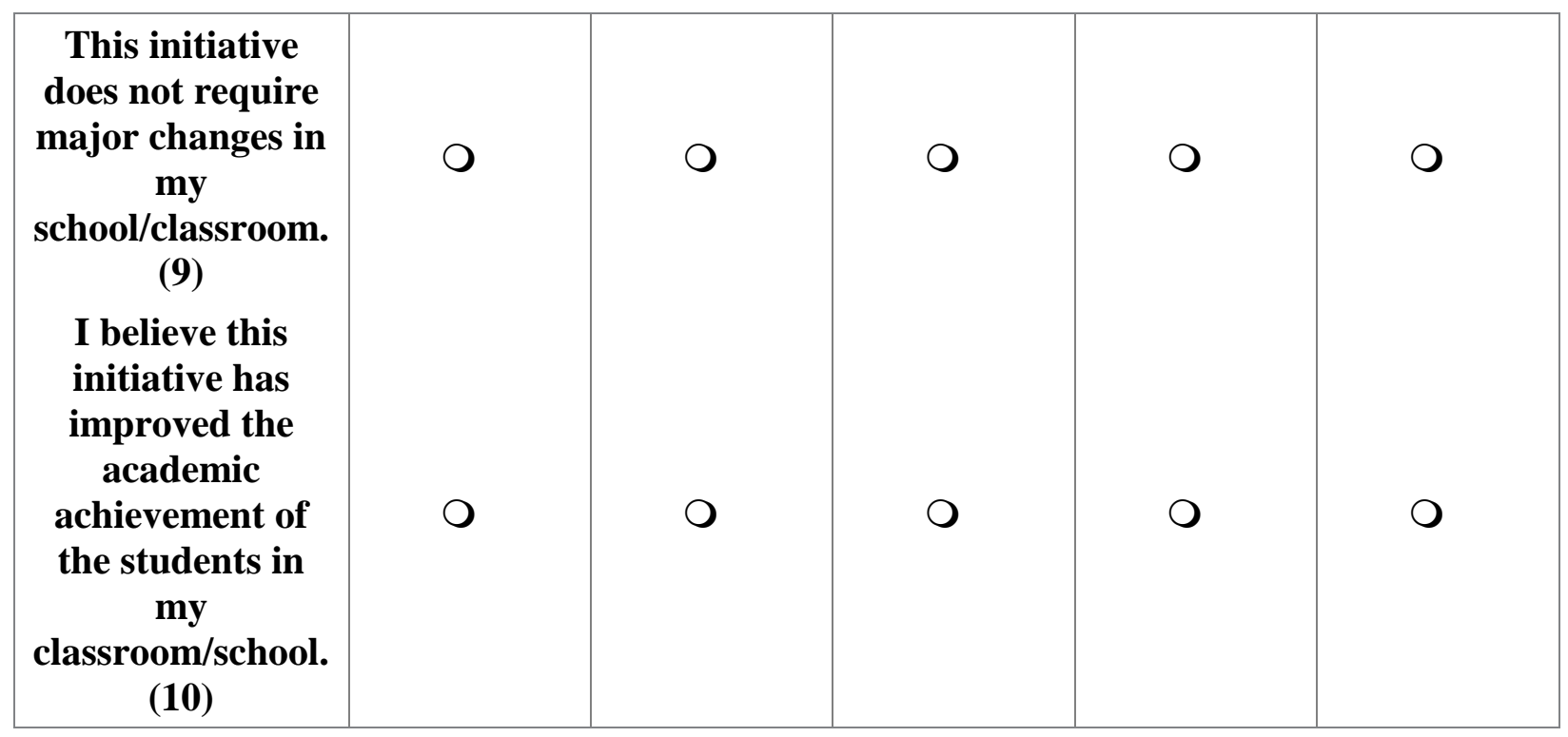

Early Screening

Early screening of children can include diagnoses of language delays, developmental delays, and health problems.

The Nationwide Children's Website (2015) reports that early interventions make a significant difference when treating children in the autism disorders spectrum. Studies have shown that children who receive early intervention and treatment for developmental disorders are more likely to graduate from high school, to hold jobs as adults, and are less likely to commit criminal acts than those who do not receive early intervention (Stoppler, 2014).

In West Virginia a Health Check or comparable comprehensive physical examination is required for enrollment into Pre-K.

Do you use this initiative in your classroom/school?

O Yes (1)

O No (2) 
Check all that apply for this initiative. 4--strongly agree; 3--agree; 2 --disagree; 1 --strongly disagree; and 0--does not apply 


\begin{tabular}{|c|c|c|c|c|c|}
\hline & $4(4)$ & $3(3)$ & $2(2)$ & $1(1)$ & $0(0)$ \\
\hline $\begin{array}{l}\text { I have had the } \\
\text { training that I } \\
\text { need to } \\
\text { implement this } \\
\text { initiative. (1) }\end{array}$ & 0 & 0 & 0 & 0 & 0 \\
\hline $\begin{array}{l}\text { I have had the } \\
\text { materials that I } \\
\text { need to } \\
\text { implement this } \\
\text { initiative. }(2)\end{array}$ & 0 & 0 & 0 & 0 & 0 \\
\hline $\begin{array}{l}\text { I have had the } \\
\text { necessary time to } \\
\text { implement this } \\
\text { initiative. (3) }\end{array}$ & 0 & $\bigcirc$ & 0 & 0 & 0 \\
\hline $\begin{array}{l}\text { Teachers have } \\
\text { had input into } \\
\text { the design of this } \\
\text { initiative. (4) }\end{array}$ & 0 & 0 & 0 & 0 & 0 \\
\hline $\begin{array}{l}\text { I have had input } \\
\text { into the } \\
\text { implementation } \\
\text { of this initiative. } \\
\text { (5) }\end{array}$ & 0 & 0 & 0 & 0 & 0 \\
\hline $\begin{array}{l}\text { I have had the } \\
\text { opportunity to } \\
\text { collaborate with } \\
\text { my colleagues } \\
\text { about this } \\
\text { initiative. (6) }\end{array}$ & 0 & 0 & 0 & 0 & 0 \\
\hline $\begin{array}{l}\text { This initiative is } \\
\text { consistent with } \\
\text { my beliefs about } \\
\text { improving the } \\
\text { academic } \\
\text { achievement of } \\
\text { my students. (7) }\end{array}$ & 0 & 0 & 0 & 0 & 0 \\
\hline $\begin{array}{l}\text { This initiative is } \\
\text { easy to } \\
\text { implement. (8) }\end{array}$ & 0 & 0 & 0 & 0 & 0 \\
\hline
\end{tabular}




\begin{tabular}{|c|c|c|c|c|c|}
\hline $\begin{array}{c}\text { This initiative } \\
\text { does not require } \\
\text { major changes in } \\
\text { my } \\
\text { classroom/school. } \\
(9) \\
\text { I believe this } \\
\text { initiative has } \\
\text { improved the } \\
\text { academic } \\
\text { achievement of } \\
\text { the students in } \\
\text { my } \\
\text { classroom/school. } \\
(10)\end{array}$ & 0 & 0 & 0 & 0 & 0 \\
\hline
\end{tabular}

\section{Comments}

School Based Health Centers and Wraparound Services

School based health centers can include dental, medical, and psychological services. Some also provide reproductive information to middle and high school students (Andrews, 2011).

Community school programs that featured more than 250 services and events were linked to positive attitudes about school for middle school students in a California study of five community schools (Castrachini \& London, 2012).

In West Virginia counties can provide health services throughout the school day to include nurses, medical providers, clinicians, dentists, dental hygienists, and counselors.

Do you use this initiative in your classroom/school?

O Yes (1)

O No (2) 
Check all that apply for this initiative. 4--strongly agree; 3--agree; 2--disagree; 1--strongly disagree; and 0--does not apply 


\begin{tabular}{|c|c|c|c|c|c|}
\hline & $4(4)$ & $3(3)$ & $2(2)$ & $1(1)$ & $0(0)$ \\
\hline $\begin{array}{l}\text { I have had the } \\
\text { training that I } \\
\text { need to } \\
\text { implement this } \\
\text { initiative. (1) }\end{array}$ & 0 & O & 0 & 0 & 0 \\
\hline $\begin{array}{l}\text { I have had the } \\
\text { materials that I } \\
\text { need to } \\
\text { implement this } \\
\text { initiative. (2) }\end{array}$ & 0 & O & 0 & 0 & 0 \\
\hline $\begin{array}{l}\text { I have had the } \\
\text { necessary time to } \\
\text { implement this } \\
\text { initiative. (3) }\end{array}$ & 0 & O & 0 & 0 & 0 \\
\hline $\begin{array}{l}\text { Teachers have } \\
\text { had input into } \\
\text { the design of this } \\
\text { initiative. (4) }\end{array}$ & 0 & O & 0 & 0 & 0 \\
\hline $\begin{array}{l}\text { I have had input } \\
\text { into the } \\
\text { implementation } \\
\text { of this initiative. } \\
\text { (5) }\end{array}$ & 0 & O & 0 & 0 & 0 \\
\hline $\begin{array}{l}\text { I have had the } \\
\text { opportunity to } \\
\text { collaborate with } \\
\text { my colleagues } \\
\text { about this } \\
\text { initiative. (6) }\end{array}$ & 0 & 0 & 0 & 0 & 0 \\
\hline $\begin{array}{l}\text { This initiative is } \\
\text { consistent with } \\
\text { my beliefs about } \\
\text { improving the } \\
\text { academic } \\
\text { achievement of } \\
\text { my students. (7) }\end{array}$ & 0 & O & 0 & 0 & 0 \\
\hline $\begin{array}{l}\text { This initiative is } \\
\text { easy to } \\
\text { implement. (8) }\end{array}$ & 0 & O & 0 & 0 & 0 \\
\hline
\end{tabular}




\begin{tabular}{|c|c|c|c|c|c|}
\hline $\begin{array}{c}\text { This initiative } \\
\text { does not require } \\
\text { major changes in } \\
\text { my } \\
\text { school/classroom. } \\
\text { (9) } \\
\text { I believe this } \\
\text { initiative has } \\
\text { improved the } \\
\text { academic } \\
\text { achievement of } \\
\text { the students in } \\
\text { my } \\
\text { classroom/school. } \\
\text { (10) }\end{array}$ & O & 0 & 0 & 0 & 0 \\
\hline
\end{tabular}

\section{Comments}

Food and Nutrition Programs.

Food and nutrition programs for families include free breakfast and lunch programs, the Child and Adult Care Food Program and nutrition programs for women who are pregnant.

Studies show that nutrition programs lead to improved behavior, attendance, and test scores (Ford, 2013). In a study of $\mathbf{5 2 0 0}$ fifth-graders, those who ate more fruits and vegetables and who had high diet quality scores including fewer calories and less saturated fat were $41 \%$ "...less likely to fail a standardized reading and writing test" ("Good Food," 2008).

In West Virginia the Department of Education administers many nutrition programs: Community Eligibility Option; National School Lunch Program; Child and Adult Care Food Program; Summer Food Service Program; Fresh Fruit and Vegetable Program; School Breakfast Program; and the Special Milk Program.

Do you use this initiative in your classroom/school?

O Yes (1)

O No (2) 
Check all that apply for this initiative. 4--strongly agree; 3--agree; 2 --disagree; 1 --strongly disagree; and 0--does not apply 


\begin{tabular}{|c|c|c|c|c|c|}
\hline & $4(4)$ & $3(3)$ & $2(2)$ & $1(1)$ & $0(0)$ \\
\hline $\begin{array}{l}\text { I have had the } \\
\text { training that I } \\
\text { need to } \\
\text { implement this } \\
\text { initiative. (1) }\end{array}$ & 0 & 0 & 0 & 0 & 0 \\
\hline $\begin{array}{l}\text { I have had the } \\
\text { materials that I } \\
\text { need to } \\
\text { implement this } \\
\text { initiative. }(2)\end{array}$ & 0 & 0 & 0 & 0 & 0 \\
\hline $\begin{array}{l}\text { I have had the } \\
\text { necessary time to } \\
\text { implement this } \\
\text { initiative. (3) }\end{array}$ & 0 & $\bigcirc$ & 0 & 0 & 0 \\
\hline $\begin{array}{l}\text { Teachers have } \\
\text { had input into } \\
\text { the design of this } \\
\text { initiative. (4) }\end{array}$ & 0 & 0 & 0 & 0 & 0 \\
\hline $\begin{array}{l}\text { I have had input } \\
\text { into the } \\
\text { implementation } \\
\text { of this initiative. } \\
\text { (5) }\end{array}$ & 0 & 0 & 0 & 0 & 0 \\
\hline $\begin{array}{l}\text { I have had the } \\
\text { opportunity to } \\
\text { collaborate with } \\
\text { my colleagues } \\
\text { about this } \\
\text { initiative. (6) }\end{array}$ & 0 & 0 & 0 & 0 & 0 \\
\hline $\begin{array}{l}\text { This initiative is } \\
\text { consistent with } \\
\text { my beliefs about } \\
\text { improving the } \\
\text { academic } \\
\text { achievement of } \\
\text { my students. (7) }\end{array}$ & 0 & 0 & 0 & 0 & 0 \\
\hline $\begin{array}{l}\text { This initiative is } \\
\text { easy to } \\
\text { implement. (8) }\end{array}$ & 0 & 0 & 0 & 0 & 0 \\
\hline
\end{tabular}




\begin{tabular}{|c|c|c|c|c|c|}
\hline $\begin{array}{c}\text { This initiative } \\
\text { does not require } \\
\text { major changes in } \\
\text { my } \\
\text { school/classroom. } \\
\text { (9) } \\
\text { I believe this } \\
\text { initiative has } \\
\text { improved the } \\
\text { academic } \\
\text { achievement of } \\
\text { the students in } \\
\text { my } \\
\text { classroom/school. } \\
(10)\end{array}$ & 0 & 0 & 0 & 0 & 0 \\
\hline
\end{tabular}

\section{Comments}

National Board Certified Teachers.

National board certification for teachers is a peer-reviewed rigorous process based on performance standards (National Board for Professional Teaching Standards, 2014).

Although there are conflicting studies of its impact on student achievement, several studies have found strong evidence that National Board Certified teachers increase student achievement (Cavalluzzo, 2004).

In West Virginia National Board certification is encouraged and financially supported through the West Virginia Legislature and the Department of Education.

Do you use this initiative in your classroom/school?

Yes (1)

No (2) 
Check all that apply for this initiative. 4--strongly agree; 3--agree; 2 --disagree; 1 --strongly disagree; and 0--does not apply 


\begin{tabular}{|c|c|c|c|c|c|}
\hline & $4(4)$ & $3(\mathbf{3})$ & $2(2)$ & $1(1)$ & $0(0)$ \\
\hline $\begin{array}{l}\text { I have had the } \\
\text { training that I } \\
\text { need to } \\
\text { implement this } \\
\text { initiative. (1) }\end{array}$ & 0 & 0 & 0 & 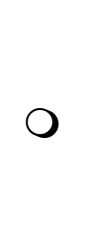 & 0 \\
\hline $\begin{array}{l}\text { I have had the } \\
\text { materials that I } \\
\text { need to } \\
\text { implement this } \\
\text { initiative. (2) }\end{array}$ & 0 & 0 & 0 & 0 & 0 \\
\hline $\begin{array}{l}\text { I have had the } \\
\text { necessary time to } \\
\text { implement this } \\
\text { initiative. (3) }\end{array}$ & 0 & 0 & 0 & 0 & 0 \\
\hline $\begin{array}{l}\text { Teachers have } \\
\text { had input into } \\
\text { the design of this } \\
\text { initiative. (4) }\end{array}$ & 0 & 0 & 0 & 0 & 0 \\
\hline $\begin{array}{l}\text { I have had input } \\
\text { into the } \\
\text { implementation } \\
\text { of this initiative. } \\
\text { (5) }\end{array}$ & 0 & 0 & 0 & 0 & 0 \\
\hline $\begin{array}{l}\text { I have had the } \\
\text { opportunity to } \\
\text { collaborate with } \\
\text { my colleagues } \\
\text { about this } \\
\text { initiative. (6) }\end{array}$ & 0 & 0 & 0 & O & $\mathrm{O}$ \\
\hline $\begin{array}{l}\text { This initiative is } \\
\text { consistent with } \\
\text { my beliefs about } \\
\text { improving the } \\
\text { academic } \\
\text { achievement of } \\
\text { my students. (7) }\end{array}$ & 0 & 0 & 0 & 0 & 0 \\
\hline $\begin{array}{l}\text { This initiative is } \\
\text { easy to } \\
\text { implement. (8) }\end{array}$ & 0 & 0 & 0 & 0 & 0 \\
\hline
\end{tabular}




\begin{tabular}{|c|c|c|c|c|c|}
\hline $\begin{array}{c}\text { This initiative } \\
\text { does not require } \\
\text { major changes in } \\
\text { my } \\
\text { school/classroom. } \\
\text { (9) } \\
\text { I believe this } \\
\text { initiative has } \\
\text { improved the } \\
\text { academic } \\
\text { achievement of } \\
\text { the students in } \\
\text { my } \\
\text { classroom/school. } \\
(10)\end{array}$ & 0 & 0 & 0 & 0 & 0 \\
\hline
\end{tabular}

\section{Comments}

Thank you for taking this survey. If I receive an email with your name and email address saying that you took the survey, you will be entered into a drawing for a $\$ 50$ gift certificate. If you would like to see the results, please email me at rander4312@aol.com., and I will send you a copy. 


\section{Appendix C}

Chart Linking Initiatives and Research

\begin{tabular}{|c|c|c|}
\hline Initiative from Research & $\begin{array}{l}\text { Research on Initiatives from } \\
\text { Literature Review }\end{array}$ & West Virginia Initiative(s) \\
\hline 1. Universal preschool & $\begin{array}{l}\text { Karoly, 2001, 2011; Frank } \\
\text { Porter Child Development } \\
\text { Institute, 2014; Schweinhart, } \\
2005\end{array}$ & Universal Pre-K \\
\hline 2. After school programs & Harvard Research Project, 2008 & $\begin{array}{l}\text { Title I Afterschool Tutoring } \\
21^{\text {st }} \text { CCLC }\end{array}$ \\
\hline $\begin{array}{l}\text { 3. Adding minutes/hours/ } \\
\text { days to school calendar }\end{array}$ & $\begin{array}{l}\text { Boulay et al., 2007; Crawford, } \\
\text { 2013; Silva, } 2012\end{array}$ & $\begin{array}{l}\text { Title I Summer School or } \\
\text { Extended Year }\end{array}$ \\
\hline $\begin{array}{l}\text { 4. Teachers' high } \\
\text { expectations }\end{array}$ & $\begin{array}{l}\text { Dweck, 2015;; Jacobsen, 1992; } \\
\text { Rhem, 1999; Rosenthal, } 1968\end{array}$ & \\
\hline $\begin{array}{l}\text { 5. Teaching resilience and } \\
\text { coping Skills }\end{array}$ & $\begin{array}{l}\text { Bernard, 1996; Borman \& } \\
\text { Rachuba 2001; Esposito, 2013; } \\
\text { Rosen, Glennie, Dalton, Lennon, } \\
\text { \& Bozick, 2010: Tileston \& } \\
\text { Darling, 2008; Werner \& Smith, } \\
1982\end{array}$ & $\begin{array}{l}\text { Responsible Students } \\
\text { Through School-Wide } \\
\text { Behavior }\end{array}$ \\
\hline $\begin{array}{l}\text { 6. Increased time in } \\
\text { physical activity }\end{array}$ & $\begin{array}{l}\text { Hellmich, 2010; Centers for } \\
\text { Disease Control and Prevention, } \\
2010\end{array}$ & $\begin{array}{l}\text { West Virginia Policy } 2520.6 \\
\text { contains the content } \\
\text { standards for a rigorous } \\
\text { physical education program } \\
\text { including the Fitnessgram. }\end{array}$ \\
\hline 7. Arts education & $\begin{array}{l}\text { Jonides, 2008; Wandell et al., } \\
2008 \text {; Kisida, Greene \& Bowen, } \\
2013\end{array}$ & \\
\hline $\begin{array}{l}\text { 8. High stakes summative } \\
\text { testing }\end{array}$ & $\begin{array}{l}\text { Reardon, 2011; Timar \& } \\
\text { Maxwell-Jolly, } 2012\end{array}$ & $\begin{array}{l}\text { Students in grades 3-11 take } \\
\text { the West Virginia General } \\
\text { Summative Assessment in }\end{array}$ \\
\hline
\end{tabular}




\begin{tabular}{|c|c|c|}
\hline & & $\begin{array}{l}\text { ELA and mathematics. This } \\
\text { includes the General } \\
\text { Summative Assessment } \\
\text { which also includes science } \\
\text { for grades } 4,6 \text {, and } 10 \text {. }\end{array}$ \\
\hline 9. Formative Assessment & $\begin{array}{l}\text { Carpenter, 1991; Fuchs, 1989; } \\
\text { New York Performance } \\
\text { Standards Consortium, } 2014\end{array}$ & $\begin{array}{l}\text { DIBELS (Dynamic } \\
\text { Indicators of Basic Early } \\
\text { Literacy Skills) (WVDE, } \\
\text { 2009). }\end{array}$ \\
\hline $\begin{array}{l}\text { 10. Response to } \\
\text { Intervention }\end{array}$ & $\begin{array}{l}\text { Klotz \& Canter, 2007; Maskill, } \\
\text { 2012; Ransford et al., } 2011\end{array}$ & $\begin{array}{l}\text { *Response to Intervention } \\
\text { offers three tiers of reading } \\
\text { instruction. }\end{array}$ \\
\hline $\begin{array}{l}\text { 11. Differentiated } \\
\text { Instruction }\end{array}$ & Ravitch, 2007; Rock et al., 2008 & $\begin{array}{l}\text { *A Differentiated } \\
\text { Instruction cadre was } \\
\text { developed for middle school } \\
\text { to provide ongoing } \\
\text { professional development in } \\
\text { differentiated instruction. }\end{array}$ \\
\hline 12. Early screening & $\begin{array}{l}\text { Johnson-Staub, 2014, Mansell, } \\
\text { 2010; Nationwide Children's } \\
\text { website, } 2015\end{array}$ & $\begin{array}{l}\text { The WV Board of } \\
\text { Education's Policy } 2525 \text { has } \\
\text { required a Health Check or } \\
\text { comparable comprehensive } \\
\text { physical examination only } \\
\text { for enrollment into Pre-K } \\
\text { since } 2007 \text { (WVDE, 2013). }\end{array}$ \\
\hline $\begin{array}{l}\text { 13. School based health } \\
\text { centers and wraparound } \\
\text { services. }\end{array}$ & $\begin{array}{l}\text { Andrews, 2011; Ravitch, 2013; } \\
\text { Louisiana Public Health } \\
\text { Institute, 2010; Castrachini \& } \\
\text { London, 2012. }\end{array}$ & $\begin{array}{l}\text { In West Virginia, counties } \\
\text { can provide health services } \\
\text { throughout the school day to } \\
\text { include nurses, medical } \\
\text { providers, clinicians, } \\
\text { dentists, dental hygienists, } \\
\text { and counselors. }\end{array}$ \\
\hline $\begin{array}{l}\text { 14. Food and nutrition } \\
\text { programs }\end{array}$ & $\begin{array}{l}\text { Ford, 2013; Good Food, 2008; } \\
\text { World Bank, 2005. }\end{array}$ & $\begin{array}{l}\text { WV participates in the } \\
\text { National School Lunch } \\
\text { Program, the School } \\
\text { Breakfast Program, the } \\
\text { Child and Adult Care Food } \\
\text { Program, Farm-to-School }\end{array}$ \\
\hline
\end{tabular}




\begin{tabular}{|l|l|l|}
\hline & & $\begin{array}{l}\text { Program, Afterschool } \\
\text { Snacks, Fresh Fruit and } \\
\text { Vegetable Program, } \\
\text { Seamless Summer Option, } \\
\text { and Special Milk Program. }\end{array}$ \\
\hline 15. NBCT teachers & $\begin{array}{l}\text { National Board for Professional } \\
\text { Teaching Standards, 2014; } \\
\text { Cavalluzzo, 2004; Vandervoort, } \\
\text { et al., 2004; Smith, et al., 2005 }\end{array}$ & $\begin{array}{l}\text { Financial support provided. } \\
\text { (WVDE, 2010). }\end{array}$ \\
\hline
\end{tabular}

*New initiative(s) with report 


\title{
Appendix D
}

\section{Teacher Invitation for Pilot Survey}

\section{WestVirginiaUniversity}

\author{
College of Education and Human Services
}

Dear Teacher:

This letter is a request for you to take part in a pilot test of a survey instrument that is being proposed to measure teachers' use and perceptions of policies and initiatives recommended to improve the academic achievement of the low socioeconomic children in West Virginia Title I schools and classrooms. This project is being conducted by Rosemary Anderson, doctoral candidate, with supervision of Dr. Helen Hazi, Professor in the College of Education and Human Services. Your participation in this project is greatly appreciated and will take approximately 15 20 minutes to complete. The survey will be sent to you electronically and returned through an anonymous process.

Your involvement in this project will be kept as confidential as legally possible. All data will be reported in the aggregate. I will not ask any information that should lead back to your identity as a participant. Your participation is completely voluntary. You may skip any question that you do not wish to answer and you may discontinue at any time. West Virginia University's Institutional Review Board's acknowledgement of this project is on file. The survey period following the sending of the survey will be one week with a reminder sent after 4 days. All teachers who email or text that they have taken the survey will be entered in a drawing for a $\$ 50$ gift certificate. (rander4312@aol.com, 304-312-8862)

I am also conducting interviews with teachers to check their experiences taking the survey and to then make necessary adjustments. If you are willing to volunteer to provide feedback on your experience taking this survey, please contact Rosemary Anderson at 304-547-1414 or rander4312@aol.com. The four teachers who volunteer to be interviewed will receive a \$20 gift card in appreciation. Interviews will be recorded in order that I can check for accuracy. No one will be recorded without permission.

I hope that you will participate in this research project, as it could be beneficial in providing policy makers and education leaders with input about teachers' use and perceptions of these policies and initiatives. This instrument will also give these same policy makers and leaders insight into the factors that impede or facilitate implementation of the policies and initiatives. Thank you very much for your time. Should you have any questions about this letter or the research project, or if you would like to see the results of this pilot test, please feel free to contact Rosemary Anderson at (304) 547-1414 or by e-mail at rander4312@aol.com. 
Thank you.

Helen M. Hazi, Ph. D.

Rosemary Anderson

Professor and Committee Chair

Doctoral Candidate

Helen.Hazi@mail.wvu.edu

Phone: 304-293-1885

Fax: 304-293-2279

\section{Department of Curriculum \& Instruction/Literacy}

Program of Educational Leadership Studies

608 Allen PO Box 6122

Morgantown, WV 26506-6122
Equal opportunity/Affirmative Action Institution 


\title{
Appendix E
}

\section{Panel Request}

\section{WestVirginiaUniversity}

\author{
College of Education and Human Services
}

\section{Dear Panel Member:}

My name is Rosemary Anderson and I am a doctoral candidate in Educational Leadership Studies at West Virginia University. I am writing to ask you to serve on a panel of distinguished experts to check the validity of a set of survey questions about initiatives intended to address the academic achievement of the low socioeconomic subset in Title I schools in West Virginia. This research will develop a valid and reliable instrument to measure teachers' use and perceptions of 16 initiatives that are intended to address the achievement gap of poor children in West Virginia Title I schools. Teachers will also be asked four demographic questions to see if these variables impact their perceptions of these initiatives: Programmatic Level, Years of experience, Age, and Gender. They will also be asked to list their county. In addition they will be asked to give their perceptions of ten factors that have been shown to influence the implementation of initiatives. This instrument will be piloted with 31 teachers at a West Virginia Title I Elementary school.

As a former teacher who spent 37 years in Title I schools, I have witnessed the impact of poverty on students. I also believe that teachers who are in Title I schools have valuable knowledge that they can share about the use of these initiatives and whether these initiatives improve student achievement. I would be honored to have your input into the validity.

These four research questions are the basis for the development of this instrument.

1. What initiatives directed toward improving academic achievement of the low socioeconomic subset have West Virginia teachers used in their Title I schools

2. According to teachers in West Virginia Title I schools, have these initiatives improved the achievement of their students?

3. Is there a significant difference between selected demographics and teacher perceptions of initiatives directed at improving the academic achievement of their students in West Virginia Title I schools?

4. How do teachers perceive factors that have been shown to influence the implementation of initiatives?

If you are willing to evaluate the validity of these initiative items, please see the attached: 
- Teacher Survey

- Interventions Linked to Research

- Survey Item Review for Panel

- Chapter 2

- References

Please indicate by email as soon as possible if you are willing to serve.

Thank you very much for your consideration.

Helen M. Hazi, Ph. D.

Professor and Committee Chair

Attachment: Teacher Invitation and Cover Letter

\author{
Rosemary Anderson \\ Doctoral Candidate
}

Helen.Hazi@mail.wvu.edu Phone: 304-293-1885

Fax: 304-293-2279
Department of Curriculum \& Instruction/Literacy Program of Educational Leadership Studies 608 Allen PO Box 6122

Morgantown, WV 26506-6122
Equal opportunity/Affirmative Action Institution 


\section{Appendix F}

\section{Panel Item Review}

Directions to Panel:

The instrument (titled IRB Copy of Survey) has three sections: 1) Dear Participant, 2) Teacher Demographics (5 questions), and 3) Part 2 Interventions. In the Dear Participant, teachers are provided these directions:

\section{Dear Participant:}

This is a request for you to take part in a pilot test of a survey instrument that is being proposed to measure teachers' use and perceptions of policies and initiatives recommended to improve the academic achievement of the low socioeconomic children in West Virginia Title I schools and classrooms. All of these policies and initiatives have a base in researched studies.

Part 1: Demographics: Please answer the demographic questions. You may leave items blank.

Part 2: Initiatives: In this section, you will be asked if you use a particular initiative. If you answer yes, you will be asked to rate a series of policy factors as either strongly agree (4), agree (3), disagree (2), or strongly disagree (1). If this factor does not apply or if you are not sure, you may choose does not apply (0). You will be asked whether you have had training, materials, etc. Some factors will not apply to the particular initiative or policy, so you can mark does not apply.

Thank you.

2) Teacher Demographics section Teacher Demographics section contains 5 questions related to variables found in the literature. These include: Programmatic Level, Years of experience, Age, Gender, and County.

3) Part 2 Interventions. Each intervention has: 1) a title and a 2) description with research. For example: 


\section{After School Programs}

These programs can be run by school districts, nonprofit organizations, national organizations such as the Boys and Girls Club, or by for-profit entities. They may connect to the regular school day but can also be independent of the school. A meta-analysis of $\mathbf{3 5}$ studies of after school programs in urban, suburban, and rural locations showed significant positive effects on reading and math achievement (Laurer et al., 2006).

In West Virginia Title I Afterschool and 21st Century Community Learning Centers are initiatives in this category.

Title I afterschool provides tutoring in reading and/or math at the end of the school day through the ESEA Title I program.

The research is found in the following attached •) Interventions linked to research, •) Chapter 2, and $\bullet$ ) found in the References.

A question follows the description, "Do you use this initiative in your classroom/school?"

If YES, then a dropdown menu provides 4) a list of 9 factors affecting implementation, with the final question asking them if they believe the initiative has improved the achievement of the students in my classroom/school. Space is also provided for comments.

If $\mathrm{NO}$, then the teacher goes on to the next Intervention. 
Check all that apply for this initiative

4--strongly agree; 3--agree; 2--disagree; 1--strongly disagree; and 0--does not apply

\begin{tabular}{|c|c|c|c|c|c|}
\hline & 4 & 3 & 2 & 1 & 0 \\
\hline I have had adequate training. & 0 & 0 & $\mathrm{O}$ & 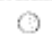 & 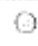 \\
\hline I have had adequate materials. & 0 & $\bigcirc$ & 0 & $\odot$ & 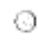 \\
\hline $\begin{array}{l}\text { I have had adequate time to } \\
\text { implement this initiative. }\end{array}$ & $\odot$ & $\odot$ & $\bigcirc$ & $\odot$ & $\odot$ \\
\hline $\begin{array}{l}\text { Teachers have had input into } \\
\text { the design of this initiative. }\end{array}$ & 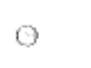 & 0 & 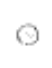 & 0 & $\odot$ \\
\hline $\begin{array}{l}\text { I have had input into the } \\
\text { implementation of this initiative. }\end{array}$ & $\mathrm{O}$ & 0 & $\mathrm{O}$ & $\Theta$ & $\odot$ \\
\hline $\begin{array}{l}\text { I have had the opportunity to } \\
\text { collaborate with my colleagues } \\
\text { about this initiative. }\end{array}$ & 0 & $\mathrm{O}$ & ९ & $\mathrm{O}$ & $\odot$ \\
\hline $\begin{array}{l}\text { This initiative is consistent with } \\
\text { my beliefs about improving the } \\
\text { academic achievement of my } \\
\text { students. }\end{array}$ & $\odot$ & $\mathrm{O}$ & $\odot$ & $\bigcirc$ & ○ \\
\hline $\begin{array}{l}\text { This initiative is easy to } \\
\text { implement }\end{array}$ & $\odot$ & $\odot$ & $\odot$ & $\ominus$ & $\odot$ \\
\hline $\begin{array}{l}\text { This initlative does not require } \\
\text { any major changes in my } \\
\text { school/classroom. }\end{array}$ & $\mathrm{O}$ & $\mathrm{O}$ & $\odot$ & 9 & $\mathrm{O}$ \\
\hline $\begin{array}{l}\text { I believe that this initiative has } \\
\text { improved the academic } \\
\text { achievement of the students in } \\
\text { my classroom/school. }\end{array}$ & 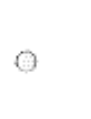 & $\odot$ & 0 & $\odot$ & $\odot$ \\
\hline
\end{tabular}

Do you have any comments about directions, demographics, factors affecting implementation, or design thus far? 
As a member of the panel, please provide feedback on the following descriptions of the interventions by marking "yes' and "no" or revising item.

\begin{tabular}{|l|l|l|l|l|}
\hline Intervention & $\begin{array}{l}\text { Item is } \\
\text { clearly } \\
\text { worded. }\end{array}$ & $\begin{array}{l}\text { Item is } \\
\text { pertinent to } \\
\text { study and } \\
\text { research } \\
\text { questions. }\end{array}$ & $\begin{array}{l}\text { Keep/Delete } \\
\text { /Modify this } \\
\text { item. }\end{array}$ & Comments \\
\hline $\begin{array}{l}\text { 1. Universal preschool. } \\
\text { Preschool is one strategy that has been used to } \\
\text { give poor children the ability to enter first } \\
\text { grade with the skills and language ability of } \\
\text { their more affluent peers. Quality preschool } \\
\text { programs can have positive effects on high } \\
\text { school graduation, achievement scores, future } \\
\text { employment, and economic security and can } \\
\text { reduce delinquency rates and special education } \\
\text { placements (Frank Porter Graham Child } \\
\text { Development Institute, 2014; Schweinhart, } \\
\text { 2005; Frank Porter Graham Child }\end{array}$ & & & \\
\begin{tabular}{l} 
Development Institute, 2014). \\
\hline
\end{tabular} & & & \\
\hline
\end{tabular}




\begin{tabular}{|c|c|c|c|c|}
\hline Intervention & $\begin{array}{l}\text { Item is } \\
\text { clearly } \\
\text { worded. }\end{array}$ & $\begin{array}{l}\text { Item is } \\
\text { pertinent } \\
\text { to study } \\
\text { and } \\
\text { research } \\
\text { questions. }\end{array}$ & $\begin{array}{l}\text { Keep/Delete/ } \\
\text { Modify this } \\
\text { item. }\end{array}$ & Comments \\
\hline $\begin{array}{l}\text { 2. After School Programs. } \\
\text { These programs can be run by school districts, } \\
\text { nonprofit organizations, national organizations } \\
\text { such as the Boys and Girls Club, or by for- } \\
\text { profit entities. Programs may connect to the } \\
\text { regular school day but can also be independent } \\
\text { of the school. A meta-analysis of } 35 \text { studies of } \\
\text { after school programs in urban, suburban, and } \\
\text { rural locations showed that after school } \\
\text { activities can have significant positive effects } \\
\text { on reading and math achievement (Laurer et } \\
\text { al., 2006). }\end{array}$ & & & & \\
\hline $\begin{array}{l}\text { 3. Adding minutes/hours/ days to school } \\
\text { calendar. } \\
\text { In these district-run extended day or expanded } \\
\text { learning time programs, the regular school day } \\
\text { and/or year is extended, providing more time } \\
\text { for the district to provide instruction. Research } \\
\text { is mixed about the results of adding minutes } \\
\text { and/or days but it is clear that it is the quality } \\
\text { of extra time and not the length that is } \\
\text { important (Silva, 2012). }\end{array}$ & & & & \\
\hline
\end{tabular}




\begin{tabular}{|c|c|c|c|c|}
\hline Intervention & $\begin{array}{l}\text { Item is } \\
\text { clearly } \\
\text { worded. }\end{array}$ & $\begin{array}{l}\text { Item is } \\
\text { pertinent } \\
\text { to study } \\
\text { and } \\
\text { research } \\
\text { questions. }\end{array}$ & $\begin{array}{l}\text { Keep/Delete/ } \\
\text { Modify this } \\
\text { item. }\end{array}$ & Comments \\
\hline $\begin{array}{l}\text { 4. Teachers' high expectations. } \\
\text { Teachers' beliefs and high expectations } \\
\text { directly influence students' academic } \\
\text { experiences. Students perform better when } \\
\text { teachers believe they are competent (Johns, } \\
\text { Schmader, \& Martens, 2005; Rosenthal \& } \\
\text { Jacobsen, 1992). }\end{array}$ & & & & \\
\hline $\begin{array}{l}\text { 5. Teaching resilience and coping skills. } \\
\text { Teaching resilience and coping skills includes } \\
\text { teaching appropriate responses, providing } \\
\text { students with a locus of control, increasing } \\
\text { students' efficacy, recognizing and respecting } \\
\text { relationships, incorporating students' different } \\
\text { cultures and backgrounds, and teaching } \\
\text { planning and organization and cause and effect } \\
\text { (Tileston \& Darling, 2008). }\end{array}$ & & & & \\
\hline
\end{tabular}




\begin{tabular}{|c|c|c|c|c|}
\hline Intervention & $\begin{array}{l}\text { Item is } \\
\text { clearly } \\
\text { worded. }\end{array}$ & $\begin{array}{l}\text { Item is } \\
\text { pertinent } \\
\text { to study } \\
\text { and } \\
\text { research } \\
\text { questions. }\end{array}$ & $\begin{array}{l}\text { Keep/Delete/ } \\
\text { Modify this } \\
\text { item. }\end{array}$ & Comments \\
\hline $\begin{array}{l}\text { 6. Increased time in physical activity. } \\
\text { Increasing the amount of time in physical } \\
\text { education classes, providing physical activities in } \\
\text { the classroom, and providing recess time has been } \\
\text { shown to have positive effects on cognitive skills } \\
\text { and attitudes, academic behavior, and academic } \\
\text { achievement (Hellmich, 2010). }\end{array}$ & & & & \\
\hline $\begin{array}{l}\text { 7. Arts education } \\
\text { Arts education is used for a range of desirable } \\
\text { outcomes including math ability, memory skills, } \\
\text { and reading. Training in music has been found to } \\
\text { improve cognitive memory by making strategic } \\
\text { changes in the brain where retrievable memories } \\
\text { are maintained (Jonides, 2008). Education in } \\
\text { visual arts has also been shown to improve math } \\
\text { calculation (Wandell et al., 2008, p. 52). }\end{array}$ & & & & \\
\hline $\begin{array}{l}\text { 8. High stakes summative testing. } \\
\text { High-stakes summative standardized testing is } \\
\text { linked to state and national standards and student } \\
\text { and teacher evaluation. These tests are typically } \\
\text { standardized and are marketed by testing } \\
\text { companies. Although they can be used in a } \\
\text { formative way, these tests are usually summative } \\
\text { and used to compare groups, students, and teachers } \\
\text { (Reardon, 2011; Timar \& Maxwell-Jolly, } \\
\text { 2012). }\end{array}$ & & & & \\
\hline
\end{tabular}




\begin{tabular}{|c|c|c|c|c|}
\hline Intervention & $\begin{array}{l}\text { Item is } \\
\text { clearly } \\
\text { worded. }\end{array}$ & $\begin{array}{l}\text { Item is } \\
\text { pertinent } \\
\text { to study } \\
\text { and } \\
\text { research } \\
\text { questions. }\end{array}$ & $\begin{array}{l}\text { Keep/Delete/ } \\
\text { Modify this } \\
\text { item. }\end{array}$ & Comments \\
\hline $\begin{array}{l}\text { 9. Formative testing. } \\
\text { Formative testing is primarily used to diagnose } \\
\text { problems or check progress. A New York City } \\
\text { model in which teachers used formative } \\
\text { performance assessment for evaluation showed } \\
\text { better long term benefits for students including } \\
\text { fewer dropouts and more students attending and } \\
\text { finishing college. The tests are created by teachers } \\
\text { and include performance tasks (New York } \\
\text { Performance Standards Consortium, 2014). }\end{array}$ & & & & \\
\hline $\begin{array}{l}\text { 11. Differentiated Instruction. } \\
\text { In practice, it involves “...offering several different } \\
\text { learning experiences in response to students' varied } \\
\text { needs” (Ravitch, 2007, p. 75). Although there is } \\
\text { limited research on the effects of differentiated } \\
\text { instruction, most studies show a positive } \\
\text { correlation with achievement and attitude (Rock et } \\
\text { al., 2008). }\end{array}$ & & & & \\
\hline
\end{tabular}




\begin{tabular}{|c|c|c|c|c|}
\hline Intervention & $\begin{array}{l}\text { Item is } \\
\text { clearly } \\
\text { worded. }\end{array}$ & $\begin{array}{l}\text { Item is } \\
\text { pertinent } \\
\text { to study } \\
\text { and } \\
\text { research } \\
\text { questions. }\end{array}$ & $\begin{array}{l}\text { Keep/Delete/ } \\
\text { Modify this } \\
\text { item. }\end{array}$ & Comments \\
\hline $\begin{array}{l}\text { 12. Early screening. } \\
\text { Early screening of children can include diagnoses } \\
\text { of language delays, developmental delays, and } \\
\text { health problems. The Nationwide Children's } \\
\text { website (2015) reports that early interventions } \\
\text { make a significant difference when treating } \\
\text { children in the autism disorders spectrum. In the } \\
\text { Millennium Cohort study, the correlation } \\
\text { between performance at nine months and five } \\
\text { years was said to be significant even after the } \\
\text { researchers considered the impact of poverty } \\
\text { on children's development (Mansell, 2010). }\end{array}$ & & & & \\
\hline $\begin{array}{l}\text { 13. School based health centers and wraparound } \\
\text { services. } \\
\text { School based health centers can include dental, } \\
\text { medical, and psychological services. Some also } \\
\text { provide reproductive information to middle and } \\
\text { high school students (Andrews, 2011). Community } \\
\text { school programs that featured more than } 250 \\
\text { services and events were linked to positive } \\
\text { attitudes about school for middle school students in } \\
\text { a California study of five community schools } \\
\text { (Castrachini \& London, 2012). }\end{array}$ & & & & \\
\hline $\begin{array}{l}\text { 14. Food and Nutrition Programs. } \\
\text { Food and nutrition programs for families include } \\
\text { free breakfast and lunch programs, the Child and } \\
\text { Adult Care Food Program and nutrition programs } \\
\text { for women who are pregnant. Studies show that }\end{array}$ & & & & \\
\hline
\end{tabular}


nutrition programs lead to improved behavior,

attendance, and test scores (Ford, 2013). 


\begin{tabular}{|l|l|l|l|l|}
\hline Intervention & $\begin{array}{l}\text { Item is } \\
\text { clearly } \\
\text { worded. }\end{array}$ & $\begin{array}{l}\text { Item is } \\
\text { pertinent } \\
\text { to study } \\
\text { and } \\
\text { research } \\
\text { questions. }\end{array}$ & $\begin{array}{l}\text { Keep/Delete/ } \\
\text { Modify this } \\
\text { item. }\end{array}$ & Comments \\
\hline $\begin{array}{l}\text { 15. National Board Certified Teachers. } \\
\text { National board certification for teachers is a } \\
\text { peer- reviewed rigorous process based on } \\
\text { performance standards (National Board for } \\
\text { Professional Teaching Standards, 2014). } \\
\begin{array}{l}\text { Although there are conflicting studies of the } \\
\text { impact of National Board Certified Teachers } \\
\text { on student achievement, several studies have } \\
\text { found strong evidence that National Board } \\
\text { Certified teachers increase student }\end{array}\end{array}$ & & & \\
achievement (Cavalluzzo, 2004). & & & \\
\hline
\end{tabular}

Thank you for your response! 


\section{Appendix G}

\section{Panel Review Results}

\begin{tabular}{|c|c|c|c|c|}
\hline Initiative & $\begin{array}{l}\text { Item is } \\
\text { clearly } \\
\text { worded. }\end{array}$ & $\begin{array}{l}\text { Item is } \\
\text { pertinent to } \\
\text { study and } \\
\text { research } \\
\text { questions. }\end{array}$ & $\begin{array}{l}\text { Keep/Delete } \\
\text { /Modify this } \\
\text { item. }\end{array}$ & Comments \\
\hline $\begin{array}{l}\text { 1. Universal preschool. } \\
\text { Preschool is one strategy that has been used to } \\
\text { give poor children the ability to enter first } \\
\text { grade with the skills and language ability of } \\
\text { their more affluent peers. Quality preschool } \\
\text { programs can have positive effects on high } \\
\text { school graduation, achievement scores, future } \\
\text { employment, and economic security and can } \\
\text { reduce delinquency rates and special education } \\
\text { placements (Frank Porter Graham Child } \\
\text { Development Institute, 2014; Schweinhart, } \\
\text { 2005; Frank Porter Graham Child } \\
\text { Development Institute, 2014). }\end{array}$ & Yes (4) & Yes (4) & Keep (4) & $\begin{array}{l}\text { It might be good to give ages you are } \\
\text { referencing. Is Head Start understood here? } \\
\text { The ages for preschool 3-5 were added to } \\
\text { the survey. }\end{array}$ \\
\hline
\end{tabular}




\begin{tabular}{|c|c|c|c|c|}
\hline Initiative & $\begin{array}{l}\text { Item is } \\
\text { clearly } \\
\text { worded. }\end{array}$ & $\begin{array}{l}\text { Item is } \\
\text { pertinent } \\
\text { to study } \\
\text { and } \\
\text { research } \\
\text { questions. }\end{array}$ & $\begin{array}{l}\text { Keep/Delete/ } \\
\text { Modify this } \\
\text { item. }\end{array}$ & Comments \\
\hline $\begin{array}{l}\text { 2. After School Programs. } \\
\text { These programs can be run by school districts, } \\
\text { nonprofit organizations, national organizations } \\
\text { such as the Boys and Girls Club, or by for- } \\
\text { profit entities. They may connect to the regular } \\
\text { school day but can also be independent of the } \\
\text { school. A meta-analysis of } 35 \text { studies of after } \\
\text { school programs in urban, suburban, and rural } \\
\text { locations showed that after school activities } \\
\text { can have significant positive effects on reading } \\
\text { and math achievement (Laurer et al., 2006). }\end{array}$ & Yes (4) & Yes (4) & $\begin{array}{l}\text { Keep (Yes) } \\
\text { Keep/Modify } \\
\text { (1) }\end{array}$ & $\begin{array}{l}\text { 1. Should you distinguish among } \\
\text { elementary, middle and high school level? } \\
\text { Specific programmatic information is } \\
\text { included in the demographics section. } \\
\text { 2. Change "they" in sentence } 2 \text { to } \\
\text { activities. Sentence three references } \\
\text { research with evidence for program } \\
\text { positive outcomes. The wording is } \\
\text { different than Intervention } 1 \text {. Above it is } \\
\text { framed as "can" have positive impact. This } \\
\text { intervention is worded as "showed } \\
\text { significant pos. effect." I would make sure } \\
\text { the language across all is consistent. I } \\
\text { would use "can" or "has been shown" to } \\
\text { yield positive results. } \\
\text { Language in survey now reflects the } \\
\text { word programs instead of "they". The } \\
\text { word "can" and "has been shown" are } \\
\text { used in place of "showed," etc. }\end{array}$ \\
\hline $\begin{array}{l}\text { 3. Adding minutes/hours/ days to school } \\
\text { calendar. }\end{array}$ & Yes (4) & Yes (4) & Keep (3) & $\begin{array}{l}\text { I would try to be as consistent as possible. } \\
\text { "Research is mixed" as compared to "can" } \\
\text { have positive impact and "showed }\end{array}$ \\
\hline
\end{tabular}




\begin{tabular}{|c|c|c|c|c|}
\hline $\begin{array}{l}\text { In these district-run extended day or expanded } \\
\text { learning time programs, the regular school day } \\
\text { and/or year is extended, providing more time } \\
\text { for the district to provide instruction. Research } \\
\text { is mixed about the results of adding minutes } \\
\text { and/or days but it is clear that it is the quality } \\
\text { of extra time and not the length that is } \\
\text { important (Silva, 2012). }\end{array}$ & & & $\begin{array}{l}\text { Keep/Modify } \\
\text { (1) }\end{array}$ & $\begin{array}{l}\text { significant pos. effect" could influence } \\
\text { respondents. Personally, I would use "can" } \\
\text { language and leave it to the respondent to } \\
\text { gauge whether in their experience they } \\
\text { have found a compelling argument for the } \\
\text { intervention's impact. } \\
\text { New language was incorporated in } \\
\text { initiative } 2 \text { but the phrase "Research is } \\
\text { mixed" had a different connotation so } \\
\text { the study language was not changed. }\end{array}$ \\
\hline Initiative & $\begin{array}{l}\text { Item is } \\
\text { clearly } \\
\text { worded. }\end{array}$ & $\begin{array}{l}\text { Item is } \\
\text { pertinent } \\
\text { to study } \\
\text { and } \\
\text { research } \\
\text { questions. }\end{array}$ & $\begin{array}{l}\text { Keep/Delete/ } \\
\text { Modify this } \\
\text { item. }\end{array}$ & Comments \\
\hline $\begin{array}{l}\text { 5. Teaching resilience and coping skills. } \\
\text { Teaching resilience and coping skills includes } \\
\text { teaching appropriate responses, providing } \\
\text { students with a locus of control, increasing } \\
\text { students' efficacy, recognizing and respecting } \\
\text { relationships, incorporating students' different }\end{array}$ & Yes (4) & Yes (4) & $\begin{array}{l}\text { Keep (3) } \\
\text { Keep/Modify } \\
(1)\end{array}$ & $\begin{array}{l}\text { 1. Important multiple interventions that do } \\
\text { not seem to fit into one statement. } \\
\text { The terms were combined in the } \\
\text { literature review. }\end{array}$ \\
\hline
\end{tabular}




\begin{tabular}{|l|l|l|l|}
\hline $\begin{array}{l}\text { cultures and backgrounds, and teaching } \\
\text { planning and organization and cause and effect } \\
\text { (Tileston \& Darling, 2008). }\end{array}$ & & $\begin{array}{l}\text { This is description only. I would add some } \\
\text { reference to the research as you did in } \\
\text { previous items. Or, I would add some } \\
\text { reference to research outcomes and stick to } \\
\text { just description for all items. I would do } \\
\text { the latter. However, either way is fine, just } \\
\text { be consistent. }\end{array}$ \\
A 35 year study by Werner and Smith \\
study was added to the survey item.
\end{tabular}




\begin{tabular}{|c|c|c|c|c|}
\hline Initiative & $\begin{array}{l}\text { Item is } \\
\text { clearly } \\
\text { worded. }\end{array}$ & $\begin{array}{l}\text { Item is } \\
\text { pertinent } \\
\text { to study } \\
\text { and } \\
\text { research } \\
\text { questions. }\end{array}$ & $\begin{array}{l}\text { Keep/Delete/ } \\
\text { Modify this } \\
\text { item. }\end{array}$ & Comments \\
\hline $\begin{array}{l}\text { 6. Increased time in physical activity. } \\
\text { Increasing the amount of time in physical } \\
\text { education classes, providing physical activities in } \\
\text { the classroom, and providing recess time have been } \\
\text { shown to have positive effects on cognitive skills } \\
\text { and attitudes, academic behavior, and academic } \\
\text { achievement (Hellmich, 2010). }\end{array}$ & Yes (4) & Yes (4) & $\begin{array}{l}\text { Keep (3) } \\
\text { Keep/Modify } \\
\text { (1) }\end{array}$ & $\begin{array}{l}\text { 1. Perhaps quote is incorrect-but it should } \\
\text { be "have" for plural statement. } \\
\text { Corrected. } \\
\text { 2. I would just revise to read "has been } \\
\text { shown to have positive effects on..." } \\
\text { The language was changed to this new } \\
\text { language. }\end{array}$ \\
\hline $\begin{array}{l}\text { 7. Arts education } \\
\text { Arts education is used for a range of desirable } \\
\text { outcomes including math ability, memory skills, } \\
\text { and reading. Training in music has been found to } \\
\text { improve cognitive memory by making strategic } \\
\text { changes in the brain where retrievable memories } \\
\text { are maintained (Jonides, 2008). Education in } \\
\text { visual arts has also been shown to improve math } \\
\text { calculation (Wandell et al., 2008, p. 52). }\end{array}$ & Yes (4) & Yes (4) & $\begin{array}{l}\text { Keep (3) } \\
\text { Keep/Modify } \\
\text { (1) }\end{array}$ & $\begin{array}{l}\text { I would change sentence three to read "has } \\
\text { also been shown to improve math } \\
\text { calculation abilities." } \\
\text { Language was changed. }\end{array}$ \\
\hline $\begin{array}{l}\text { 8. High stakes summative testing. } \\
\text { High-stakes summative standardized testing is } \\
\text { linked to state and national standards and student } \\
\text { and teacher evaluation. These tests are typically } \\
\text { standardized and are marketed by testing } \\
\text { companies. Although they can be used in a } \\
\text { formative way, these tests are usually summative } \\
\text { and used to compare groups, students, and teachers } \\
\text { (Reardon, 2011; Timar \& Maxwell-Jolly, } 2012\end{array}$ & Yes (4) & Yes (4) & $\begin{array}{l}\text { Keep (3) } \\
\text { Keep/Modify } \\
\text { (1) }\end{array}$ & $\begin{array}{l}\text { Westest is not the correct term to use. It is } \\
\text { now called the West Virginia General } \\
\text { Summative Assessment. } \\
\text { The test name was changed in the survey. }\end{array}$ \\
\hline
\end{tabular}




\begin{tabular}{|c|c|c|c|c|}
\hline Initiative & $\begin{array}{l}\text { Item is } \\
\text { clearly } \\
\text { worded. }\end{array}$ & $\begin{array}{l}\text { Item is } \\
\text { pertinent } \\
\text { to study } \\
\text { and } \\
\text { research } \\
\text { questions. }\end{array}$ & $\begin{array}{l}\text { Keep/Delete/ } \\
\text { Modify this } \\
\text { item. }\end{array}$ & Comments \\
\hline $\begin{array}{l}\text { 9. Formative assessment. } \\
\text { Formative assessment is primarily used to diagnose } \\
\text { problems or check progress. A New York City } \\
\text { model in which teachers used formative } \\
\text { performance assessment for evaluation showed } \\
\text { better long term benefits for students including } \\
\text { fewer dropouts and more students attending and } \\
\text { finishing college. The tests are created by teachers } \\
\text { and include performance tasks (New York } \\
\text { Performance Standards Consortium, 2014). }\end{array}$ & Yes (4) & Yes (4) & $\begin{array}{l}\text { Keep (3) } \\
\text { Modify (1) }\end{array}$ & 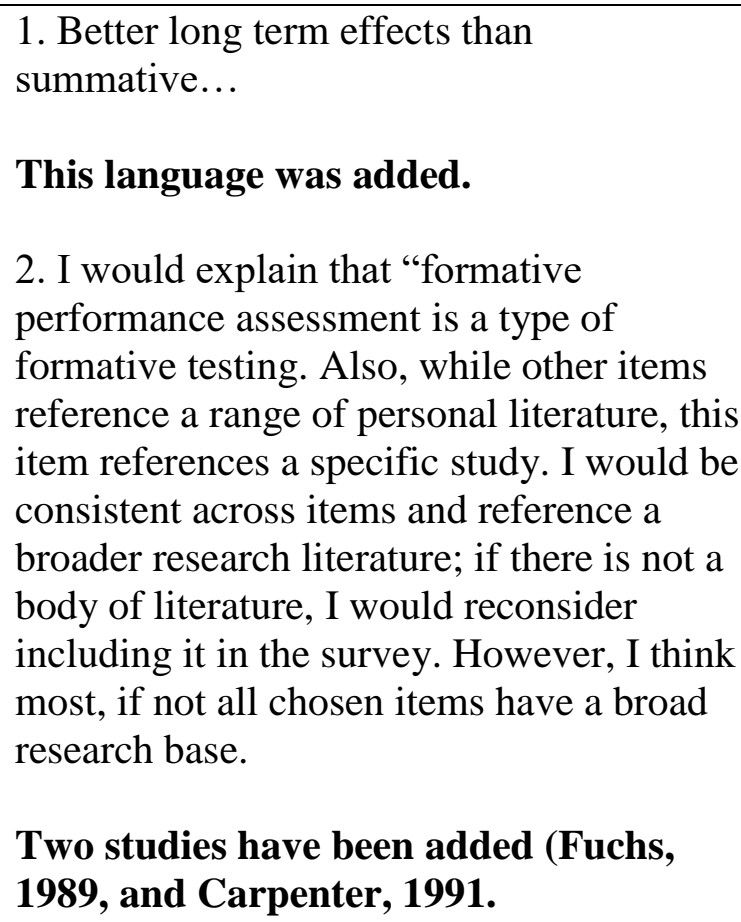 \\
\hline $\begin{array}{l}\text { 10. RTI (Response to Intervention). } \\
\text { RTI is a three-tiered approach to helping struggling } \\
\text { readers through a series of interventions based on } \\
\text { research proven programs. In a study by the } \\
\text { Society for Research on Educational Effectiveness, } \\
\text { a leveled literacy intervention program positively }\end{array}$ & Yes (4) & Yes (4) & $\begin{array}{l}\text { Keep (2) } \\
\text { Keep/Modify } \\
\text { (2) }\end{array}$ & $\begin{array}{l}\text { 1. The West Virginia Department of } \\
\text { Education renamed RTI in 2010-2011 and } \\
\text { it may be more commonly known by WV } \\
\text { educators as Support for Personalized } \\
\text { Learning (SPL). }\end{array}$ \\
\hline
\end{tabular}




\begin{tabular}{|c|c|c|c|c|}
\hline $\begin{array}{l}\text { impacted student achievement especially for } \\
\text { disadvantaged youth (Ransford-Kaldon et al., } \\
\text { 2011). }\end{array}$ & & & & $\begin{array}{l}\text { The new name was entered in the } \\
\text { survey. } \\
\text { Similar to \#9, I would reference a body of } \\
\text { literature instead of a single study. } \\
\text { A } 2010 \text { study was added to chapter } 2 \\
\text { and to the survey item. }\end{array}$ \\
\hline $\begin{array}{l}\text { 11. Differentiated Instruction. } \\
\text { In practice, it involves “... offering several different } \\
\text { learning experiences in response to students' varied } \\
\text { needs" (Ravitch, 2007, p. 75). Although there is } \\
\text { limited research on the effects of differentiated } \\
\text { instruction, most studies show a positive } \\
\text { correlation with achievement and attitude (Rock et } \\
\text { al., 2008). }\end{array}$ & Yes (4) & Yes (4) & Yes (4) & $\begin{array}{l}\text { This follows the structure of the first few } \\
\text { items in the table: defining the intervention } \\
\text { and pointing to a body of literature. I } \\
\text { would try to make all items match this } \\
\text { format. }\end{array}$ \\
\hline Initiative & $\begin{array}{l}\text { Item is } \\
\text { clearly } \\
\text { worded. }\end{array}$ & $\begin{array}{l}\text { Item is } \\
\text { pertinent } \\
\text { to study } \\
\text { and } \\
\text { research } \\
\text { questions. }\end{array}$ & $\begin{array}{l}\text { Keep/Delete/ } \\
\text { Modify this } \\
\text { item. }\end{array}$ & Comments \\
\hline $\begin{array}{l}\text { 12. Early screening. } \\
\text { Early screening of children can include diagnoses } \\
\text { of language delays, developmental delays, and } \\
\text { health problems. The Nationwide Children's } \\
\text { website (2015) reports that early interventions } \\
\text { make a significant difference when treating } \\
\text { children in the autism disorders spectrum. In the } \\
\text { Millennium Cohort study, the correlation } \\
\text { between performance at nine months and five } \\
\text { years was said to be significant even after the }\end{array}$ & Yes (4) & Yes (4) & $\begin{array}{l}\text { Keep (3) } \\
\text { Keep/Modify } \\
\text { (1) }\end{array}$ & $\begin{array}{l}\text { 1. Why only list autism? There may be a } \\
\text { broader quote. } \\
\text { The Mansell study was included which } \\
\text { was broader. } \\
\text { 2. Also, while other items reference a range } \\
\text { of research literature, this item references a } \\
\text { specific study. I would be consistent across } \\
\text { items and reference a broader research } \\
\text { literature. }\end{array}$ \\
\hline
\end{tabular}




\begin{tabular}{|c|c|c|c|c|}
\hline $\begin{array}{l}\text { researchers considered the impact of poverty } \\
\text { on children's development (Mansell, 2010). }\end{array}$ & & & & $\begin{array}{l}\text { The Mansell study was further explained } \\
\text { as consisting of } 15,000 \text { children. Stoppler } \\
\text { was added. }\end{array}$ \\
\hline $\begin{array}{l}\text { 13. School based health centers and wraparound } \\
\text { services. } \\
\text { School based health centers can include dental, } \\
\text { medical, and psychological services. Some also } \\
\text { provide reproductive information to middle and } \\
\text { high school students (Andrews, 2011). Community } \\
\text { school programs that featured more than } 250 \\
\text { services and events were linked to positive } \\
\text { attitudes about school for middle school students in } \\
\text { a California study of five community schools } \\
\text { (Castrachini \& London, 2012). }\end{array}$ & Yes (4) & Yes (4) & Keep (4) & $\begin{array}{l}\text { Can you also find a high school quote? } \\
\text { The proposed population, Title I schools, } \\
\text { will include only several high schools. }\end{array}$ \\
\hline
\end{tabular}




\begin{tabular}{|c|c|c|c|c|}
\hline Initiative & $\begin{array}{l}\text { Item is } \\
\text { clearly } \\
\text { worded. }\end{array}$ & $\begin{array}{l}\text { Item is } \\
\text { pertinent } \\
\text { to study } \\
\text { and } \\
\text { research } \\
\text { questions. }\end{array}$ & $\begin{array}{l}\text { Keep/Delete/ } \\
\text { Modify this } \\
\text { item. }\end{array}$ & Comments \\
\hline $\begin{array}{l}\text { 15. National Board Certified Teachers. } \\
\text { National board certification for teachers is a } \\
\text { peer- reviewed rigorous process based on } \\
\text { performance standards (National Board for } \\
\text { Professional Teaching Standards, 2014). } \\
\text { Although there are conflicting studies of the } \\
\text { impact of National Board Certified Teachers } \\
\text { on student achievement, several studies have } \\
\text { found strong evidence that National Board } \\
\text { Certified teachers increase student } \\
\text { achievement (Cavalluzzo, 2004). }\end{array}$ & Yes (4) & Yes (4) & Keep (4) & \\
\hline
\end{tabular}




\section{Appendix H}

\section{Superintendent Letter}

\section{West VurginiaUniversity}

\section{College of Education and Human Services}

\section{Dear Superintendent:}

In partial fulfillment of the educational leadership doctoral program at West Virginia University, I am required to conduct a pilot test of a survey at a West Virginia Title I School. The purpose of the study is to develop an instrument that will measure teachers' use and perceptions of policies and initiatives that are directed to increasing the academic achievement of students in West Virginia Title I schools and to examine teachers' perceptions of factors that affect policy implementation. I would like to do this pilot survey at an Elementary School.

The purpose of this letter is to inform you that I will be contacting the Principal at the Elementary School about a time when I can distribute invitation letters to teachers to participate in this survey. At that time I will ask for volunteers to allow me to send them an electronic survey through Qualtrics, an online survey distributor. I will be asking that all surveys be returned electronically within one week after electronic distribution. I will also ask for volunteers to be interviewed about their experience when taking the survey. These interviews will be after school. The survey will take only 15 to 20 minutes to complete. Participation is voluntary and teachers may answer all, some, or none of the questions. Results will be in aggregate form and individual responses will be confidential and anonymous.

I believe that this survey instrument will allow for valuable teacher input into discussions about policies and initiatives in West Virginia that are directed at increasing the achievement of low socioeconomic students.

Kindly indicate by email or letter that this is acceptable.

Please contact me if you have any questions at rander4312@aol.com or by phone 304-547-1414.

Thank you.

Helen M. Hazi, Ph. D.

Rosemary Anderson

Professor and Committee Chair

Doctoral Candidate

Helen.Hazi@mail.wvu.edu

Phone: 304-293-1885

Fax: 304-293-2279

\section{Department of Curriculum \& Instruction/Literacy} Program of Educational Leadership Studies 608 Allen PO Box 6122

Morgantown, WV 26506-6122
Equal opportunity/Affirmative Action Institution 


\title{
Appendix I
}

\section{Principal Letter}

\section{West VurginiaUniversity}

\author{
College of Education and Human Services
}

\section{Dear Principal:}

In partial fulfillment of the educational leadership doctoral program at West Virginia University, I am required to conduct a pilot test of a survey at a West Virginia Title I School. The purpose of the study is to develop an instrument that will measure teachers' use and perceptions of policies and initiatives that are directed to increasing the academic achievement of students in West Virginia Title I schools and to examine their perception of factors that affect policy implementation.

The purpose of this letter is to inform you that I would like to distribute an invitation to participate in this survey to the teachers at this Elementary School. I will be asking that all surveys be returned electronically within one week after distribution. I will also ask for volunteers to be interviewed about their experience when taking the survey. With their permission, those teachers will be recorded for accuracy.

The survey will take only 15 to 20 minutes to complete. Participation is voluntary and teachers may answer all, some, or none of the questions. Results will be in aggregate form and individual responses will be anonymous and confidential. I will not ask anything that could identify participants' identities.

I believe that this survey instrument will allow for valuable teacher input into discussions about policies and initiatives in West Virginia that are directed at increasing the achievement of low socioeconomic students.

I have also contacted the Superintendent.

Please contact me by letter or email if this is agreeable. If you have any questions, you can contact me at rander4312@aol.com or by phone 304-547-1414.

Thank you.

Helen M. Hazi, Ph. D.

Professor and Committee Chair
Rosemary Anderson

Doctoral Candidate

Attachment: Teacher Invitation and Cover Letter 
Department of Curriculum \& Instruction/Literacy

Helen.Hazi@mail.wvu.edu

Phone: 304-293-1885

Program of Educational Leadership Studies

Fax: 304-293-2279 Morgantown, WV 26506-6122 
Appendix J

Survey Development

\begin{tabular}{|c|c|c|c|c|}
\hline & Demographics & Initiatives & Policy Factors & $\begin{array}{l}\text { Use and } \\
\text { Academic } \\
\text { Improvement }\end{array}$ \\
\hline Prospectus & 4 & 16 & NA & $\begin{array}{l}\text { Perceptions on } \\
\text { Use and } \\
\text { Academic } \\
\text { Achievement }\end{array}$ \\
\hline Committee & County & & 9 Policy Factors & $\begin{array}{l}\text { Use now triggers } \\
\text { logic questions on } \\
\text { policy factors }\end{array}$ \\
\hline Panel & $\begin{array}{l}\text { 1. National } \\
\text { Board } \\
\text { Certification } \\
\text { 2. Highest } \\
\text { Education } \\
\text { Degree }\end{array}$ & $\begin{array}{l}\text { 1. Changed } \\
\text { wording as needed. } \\
\text { 2. Added research } \\
\text { on } 7 \text { items } \\
\text { 3. Added } \\
\text { modifications/clarif } \\
\text { ications on } 7 \text { items }\end{array}$ & & \\
\hline $\begin{array}{l}\text { Cognitive } \\
\text { Interviews }\end{array}$ & & & & $\begin{array}{l}\text { Changed stems to } \\
\text { read, This } \\
\text { initiative is used } \\
\text { in my } \\
\text { school/classroom } \\
\text { and listing only } \\
\text { what is } \\
\text { appropriate. }\end{array}$ \\
\hline $\begin{array}{l}\text { Current } \\
\text { Survey: } \\
\text { Teachers' } \\
\text { Perceptions } \\
\text { of Reform } \\
\text { Initiatives }\end{array}$ & $\begin{array}{l}7 \\
\text { Demographics }\end{array}$ & $\begin{array}{l}16 \text { Initiatives as } \\
\text { modified }\end{array}$ & $\begin{array}{l}9 \text { Policy } \\
\text { Implementation } \\
\text { Factors }\end{array}$ & $\begin{array}{l}\text { New Stems as } \\
\text { appropriate }\end{array}$ \\
\hline
\end{tabular}




\title{
Appendix K
}

Teachers' Perceptions of Reform Initiatives Survey

\begin{abstract}
Universal Preschool
Universal Preschool (ages 3-5) is one strategy that has been used to give poor children the ability to enter first grade with the skills and language ability of their more affluent peers.

Quality preschool programs can have positive effects on high school graduation, achievement scores, future employment, and economic security and can reduce delinquency rates and special education placements (Frank Porter Graham Child Development Institute, 2014; Schweinhart, 2005). Karoly's study (2001) of Head Start
\end{abstract}


showed that Whites and Latinos improved significantly in test scores and school attainment.

In West Virginia counties offer Universal Pre-K.

Is this initiative use9d in your school?

O Yes (1)

No (2)

Check all that apply for this initiative: 4--strongly agree; 3--agree; 2 --disagree; 1 --strongly disagree; and 0--does not apply 


\begin{tabular}{|c|c|c|c|c|c|}
\hline & $4(4)$ & $3(3)$ & $2(2)$ & $1(1)$ & $0(0)$ \\
\hline $\begin{array}{l}\text { I have had the } \\
\text { training that I } \\
\text { need to } \\
\text { implement this } \\
\text { initiative. (1) }\end{array}$ & 0 & O & 0 & 0 & 0 \\
\hline $\begin{array}{l}\text { I have had the } \\
\text { materials that I } \\
\text { need to } \\
\text { implement this } \\
\text { initiative. (2) }\end{array}$ & 0 & O & 0 & 0 & 0 \\
\hline $\begin{array}{l}\text { I have had the } \\
\text { necessary time to } \\
\text { implement this } \\
\text { initiative. (3) }\end{array}$ & 0 & O & 0 & 0 & 0 \\
\hline $\begin{array}{l}\text { Teachers have } \\
\text { had input into } \\
\text { the design of this } \\
\text { initiative. (4) }\end{array}$ & 0 & O & 0 & 0 & 0 \\
\hline $\begin{array}{l}\text { I have had input } \\
\text { into the } \\
\text { implementation } \\
\text { of this initiative. } \\
\text { (5) }\end{array}$ & 0 & O & 0 & 0 & 0 \\
\hline $\begin{array}{l}\text { I have had the } \\
\text { opportunity to } \\
\text { collaborate with } \\
\text { my colleagues } \\
\text { about this } \\
\text { initiative. (6) }\end{array}$ & 0 & 0 & 0 & 0 & 0 \\
\hline $\begin{array}{l}\text { This initiative is } \\
\text { consistent with } \\
\text { my beliefs about } \\
\text { improving the } \\
\text { academic } \\
\text { achievement of } \\
\text { my students. (7) }\end{array}$ & 0 & O & 0 & 0 & 0 \\
\hline $\begin{array}{l}\text { This initiative is } \\
\text { easy to } \\
\text { implement. (8) }\end{array}$ & 0 & O & 0 & 0 & 0 \\
\hline
\end{tabular}




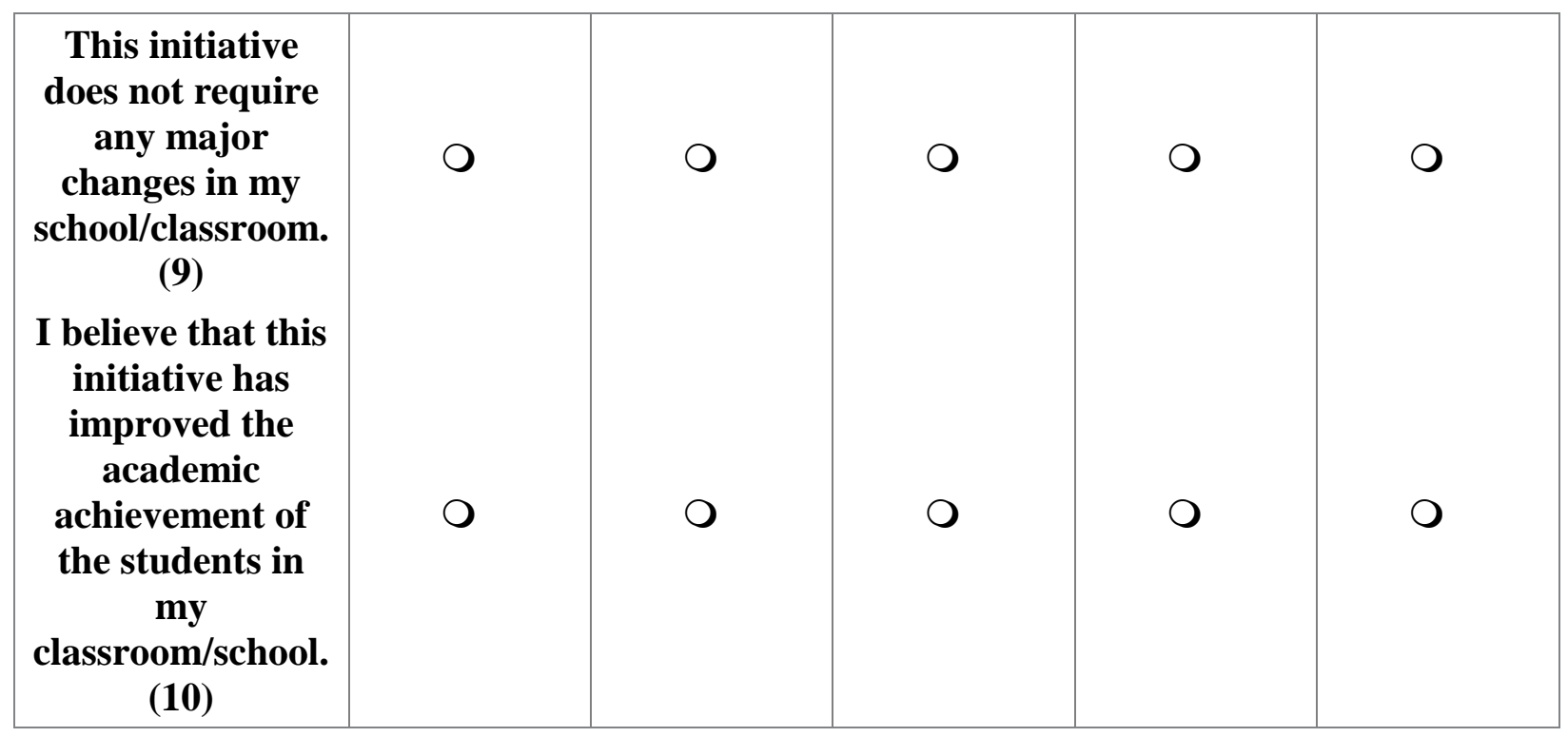

Comments

\section{After School Programs}

These programs can be run by school districts, nonprofit organizations, national organizations such as the Boys and Girls Club, or by for-profit entities. Programs may connect to the regular school day but can also be independent of the school.

A meta-analysis of 35 studies of after school programs in urban, suburban, and rural locations has been shown to have significant positive effects on reading and math achievement (Laurer et al., 2006).

In West Virginia Title I after school provides tutoring in reading and/or math at the end of the school day through the ESSA Title I program.

Is this initiative used in your school?

Yes (1)

NO (2) 
Check all that apply for this initiative. 4--strongly agree; 3--agree; 2 --disagree; 1 --strongly disagree; and 0--does not apply 


\begin{tabular}{|c|c|c|c|c|c|}
\hline & $4(4)$ & $3(3)$ & $2(2)$ & $1(1)$ & $0(0)$ \\
\hline $\begin{array}{l}\text { I have had the } \\
\text { training that I } \\
\text { need to } \\
\text { implement this } \\
\text { initiative. (1) }\end{array}$ & 0 & 0 & 0 & 0 & 0 \\
\hline $\begin{array}{l}\text { I have had the } \\
\text { materials that I } \\
\text { need to } \\
\text { implement this } \\
\text { initiative. }(2)\end{array}$ & 0 & 0 & 0 & 0 & 0 \\
\hline $\begin{array}{l}\text { I have had the } \\
\text { necessary time to } \\
\text { implement this } \\
\text { initiative. (3) }\end{array}$ & 0 & $\bigcirc$ & 0 & 0 & 0 \\
\hline $\begin{array}{l}\text { Teachers have } \\
\text { had input into } \\
\text { the design of this } \\
\text { initiative. (4) }\end{array}$ & 0 & 0 & 0 & 0 & 0 \\
\hline $\begin{array}{l}\text { I have had input } \\
\text { into the } \\
\text { implementation } \\
\text { of this initiative. } \\
\text { (5) }\end{array}$ & 0 & 0 & 0 & 0 & 0 \\
\hline $\begin{array}{l}\text { I have had the } \\
\text { opportunity to } \\
\text { collaborate with } \\
\text { my colleagues } \\
\text { about this } \\
\text { initiative. (6) }\end{array}$ & 0 & 0 & 0 & 0 & 0 \\
\hline $\begin{array}{l}\text { This initiative is } \\
\text { consistent with } \\
\text { my beliefs about } \\
\text { improving the } \\
\text { academic } \\
\text { achievement of } \\
\text { my students. (7) }\end{array}$ & 0 & 0 & 0 & 0 & 0 \\
\hline $\begin{array}{l}\text { This initiative is } \\
\text { easy to } \\
\text { implement. (8) }\end{array}$ & 0 & 0 & 0 & 0 & 0 \\
\hline
\end{tabular}




\begin{tabular}{|c|c|c|c|c|c|}
\hline $\begin{array}{c}\text { This initiative } \\
\text { does not require } \\
\text { major changes in } \\
\text { my } \\
\text { school/classroom. } \\
\text { (9) } \\
\text { I believe this } \\
\text { initiative has } \\
\text { improved the } \\
\text { academic } \\
\text { achievement of } \\
\text { the students in } \\
\text { my } \\
\text { classroom/school. } \\
(10)\end{array}$ & 0 & 0 & 0 & 0 & 0 \\
\hline
\end{tabular}

\section{Comments}

In West Virginia Twenty-first Century Community Learning Centers are another after school program. They provide a minimum of 36 weeks of 12 hours of academic and enrichment activities before and after school and in the summer.

Is this initiative used in your school?

Yes (1)

No (2) 
Check all that apply for this initiative. 4--strongly agree; 3--agree; 2 --disagree; 1 --strongly disagree; and 0--does not apply 


\begin{tabular}{|c|c|c|c|c|c|}
\hline & $4(4)$ & $3(\mathbf{3})$ & $2(2)$ & $1(1)$ & $0(0)$ \\
\hline $\begin{array}{l}\text { I have had the } \\
\text { training that I } \\
\text { need to } \\
\text { implement this } \\
\text { initiative. (1) }\end{array}$ & 0 & O & 0 & 0 & 0 \\
\hline $\begin{array}{l}\text { I have had the } \\
\text { materials that I } \\
\text { need to } \\
\text { implement this } \\
\text { initiative. (2) }\end{array}$ & 0 & O & 0 & 0 & 0 \\
\hline $\begin{array}{l}\text { I have had the } \\
\text { necessary time to } \\
\text { implement this } \\
\text { initiative. (3) }\end{array}$ & 0 & O & 0 & 0 & 0 \\
\hline $\begin{array}{l}\text { Teachers have } \\
\text { had input into } \\
\text { the design of this } \\
\text { initiative. (4) }\end{array}$ & 0 & 0 & 0 & 0 & 0 \\
\hline $\begin{array}{l}\text { I believe that } \\
\text { teachers have } \\
\text { had input into } \\
\text { the design of this } \\
\text { initiative. (5) }\end{array}$ & O & O & 0 & 0 & 0 \\
\hline $\begin{array}{l}\text { I have had the } \\
\text { opportunity to } \\
\text { collaborate with } \\
\text { my colleagues } \\
\text { about this } \\
\text { initiative. (6) }\end{array}$ & O & 0 & 0 & 0 & 0 \\
\hline $\begin{array}{l}\text { This initiative is } \\
\text { consistent with } \\
\text { my beliefs about } \\
\text { improving the } \\
\text { academic } \\
\text { achievement of } \\
\text { my students. (7) }\end{array}$ & O & O & 0 & 0 & 0 \\
\hline $\begin{array}{l}\text { This initiative is } \\
\text { easy to } \\
\text { implement. (8) }\end{array}$ & 0 & O & 0 & 0 & 0 \\
\hline
\end{tabular}




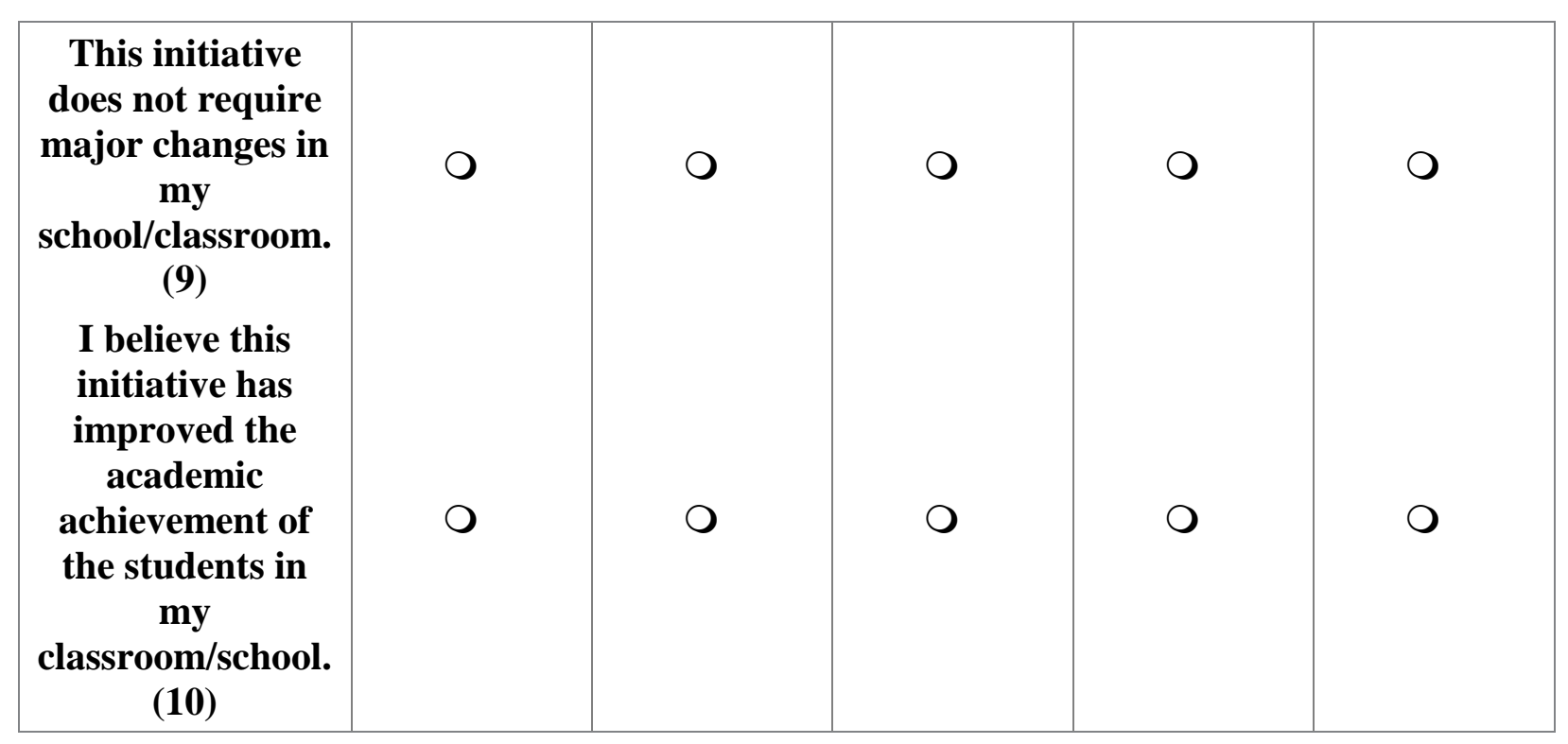

\section{Comments}

\section{Adding Minutes/Hours/Days to School Calendar}

In these district-run extended day or expanded learning time programs, the regular school day and/or year is extended, providing more time for the district to provide instruction.

Research is mixed about the results of adding minutes and/or days, but it is clear that it is the quality of extra time and not the length that is important (Silva, 2012).

In West Virginia extra time can be provided through Title I Summer School. 
Is this initiative used in your school?

Yes (1)

No (2)

Check all that apply for this initiative. 4--strongly agree; 3--agree; 2--disagree; 1--strongly disagree; and 0--does not apply 


\begin{tabular}{|c|c|c|c|c|c|}
\hline & $4(4)$ & $3(3)$ & $2(2)$ & $1(1)$ & $0(0)$ \\
\hline $\begin{array}{l}\text { I have had the } \\
\text { training that I } \\
\text { need to } \\
\text { implement this } \\
\text { initiative. (1) }\end{array}$ & 0 & 0 & 0 & 0 & 0 \\
\hline $\begin{array}{l}\text { I have had the } \\
\text { materials that I } \\
\text { need to } \\
\text { implement this } \\
\text { initiative. }(2)\end{array}$ & 0 & 0 & 0 & 0 & 0 \\
\hline $\begin{array}{l}\text { I have had the } \\
\text { necessary time to } \\
\text { implement this } \\
\text { initiative. (3) }\end{array}$ & 0 & $\bigcirc$ & 0 & 0 & 0 \\
\hline $\begin{array}{l}\text { Teachers have } \\
\text { had input into } \\
\text { the design of this } \\
\text { initiative. (4) }\end{array}$ & 0 & 0 & 0 & 0 & 0 \\
\hline $\begin{array}{l}\text { I have had input } \\
\text { into the } \\
\text { implementation } \\
\text { of this initiative. } \\
\text { (5) }\end{array}$ & 0 & 0 & 0 & 0 & 0 \\
\hline $\begin{array}{l}\text { I have had the } \\
\text { opportunity to } \\
\text { collaborate with } \\
\text { my colleagues } \\
\text { about this } \\
\text { initiative. (6) }\end{array}$ & 0 & 0 & 0 & 0 & 0 \\
\hline $\begin{array}{l}\text { This initiative is } \\
\text { consistent with } \\
\text { my beliefs about } \\
\text { improving the } \\
\text { academic } \\
\text { achievement of } \\
\text { my students. (7) }\end{array}$ & 0 & 0 & 0 & 0 & 0 \\
\hline $\begin{array}{l}\text { This initiative is } \\
\text { easy to } \\
\text { implement. (8) }\end{array}$ & 0 & 0 & 0 & 0 & 0 \\
\hline
\end{tabular}




\begin{tabular}{|c|c|c|c|c|c|}
\hline $\begin{array}{c}\text { This initiative } \\
\text { does not require } \\
\text { major changes in } \\
\text { my } \\
\text { classroom/school. } \\
(9) \\
\text { I believe this } \\
\text { initiative has } \\
\text { improved the } \\
\text { academic } \\
\text { achievement of } \\
\text { the students in } \\
\text { my } \\
\text { classroom/school. } \\
(10)\end{array}$ & 0 & 0 & 0 & 0 & 0 \\
\hline
\end{tabular}

\section{Comments}

\section{Teachers' High Expectations.}

Teachers' beliefs and high expectations may directly influence students' academic experiences. Students perform better when teachers believe they are competent (Johns, Schmader, \& Martens, 2005; Rosenthal \& Jacobsen, 1992). Students who believed that their intelligence could be developed (growth mindset) were more motivated and outperformed those who believed their intelligence was fixed (Dweck, 2015).

Is this initiative used in your classroom/school?

O Yes (1)

O No(2) 
Check all that apply for this initiative. 4--strongly agree; 3--agree; 2 --disagree; 1 --strongly disagree; and 0--does not apply 


\begin{tabular}{|c|c|c|c|c|c|}
\hline & $4(4)$ & $3(3)$ & $2(2)$ & $1(1)$ & $0(0)$ \\
\hline $\begin{array}{l}\text { I have had the } \\
\text { training that I } \\
\text { need to } \\
\text { implement this } \\
\text { initiative. (1) }\end{array}$ & 0 & 0 & 0 & 0 & 0 \\
\hline $\begin{array}{l}\text { I have had the } \\
\text { materials that I } \\
\text { need to } \\
\text { implement this } \\
\text { initiative. }(2)\end{array}$ & 0 & 0 & 0 & 0 & 0 \\
\hline $\begin{array}{l}\text { I have had the } \\
\text { necessary time to } \\
\text { implement this } \\
\text { initiative. (3) }\end{array}$ & 0 & $\bigcirc$ & 0 & 0 & 0 \\
\hline $\begin{array}{l}\text { Teachers have } \\
\text { had input into } \\
\text { the design of this } \\
\text { initiative. (4) }\end{array}$ & 0 & 0 & 0 & 0 & 0 \\
\hline $\begin{array}{l}\text { I have had input } \\
\text { into the } \\
\text { implementation } \\
\text { of this initiative. } \\
\text { (5) }\end{array}$ & 0 & 0 & 0 & 0 & 0 \\
\hline $\begin{array}{l}\text { I have had the } \\
\text { opportunity to } \\
\text { collaborate with } \\
\text { my colleagues } \\
\text { about this } \\
\text { initiative (6) }\end{array}$ & 0 & 0 & 0 & 0 & 0 \\
\hline $\begin{array}{l}\text { This initiative is } \\
\text { consistent with } \\
\text { my beliefs about } \\
\text { improving the } \\
\text { academic } \\
\text { achievement of } \\
\text { my students. (7) }\end{array}$ & 0 & 0 & 0 & 0 & 0 \\
\hline $\begin{array}{l}\text { This initiative is } \\
\text { easy to } \\
\text { implement. (8) }\end{array}$ & 0 & 0 & 0 & 0 & 0 \\
\hline
\end{tabular}




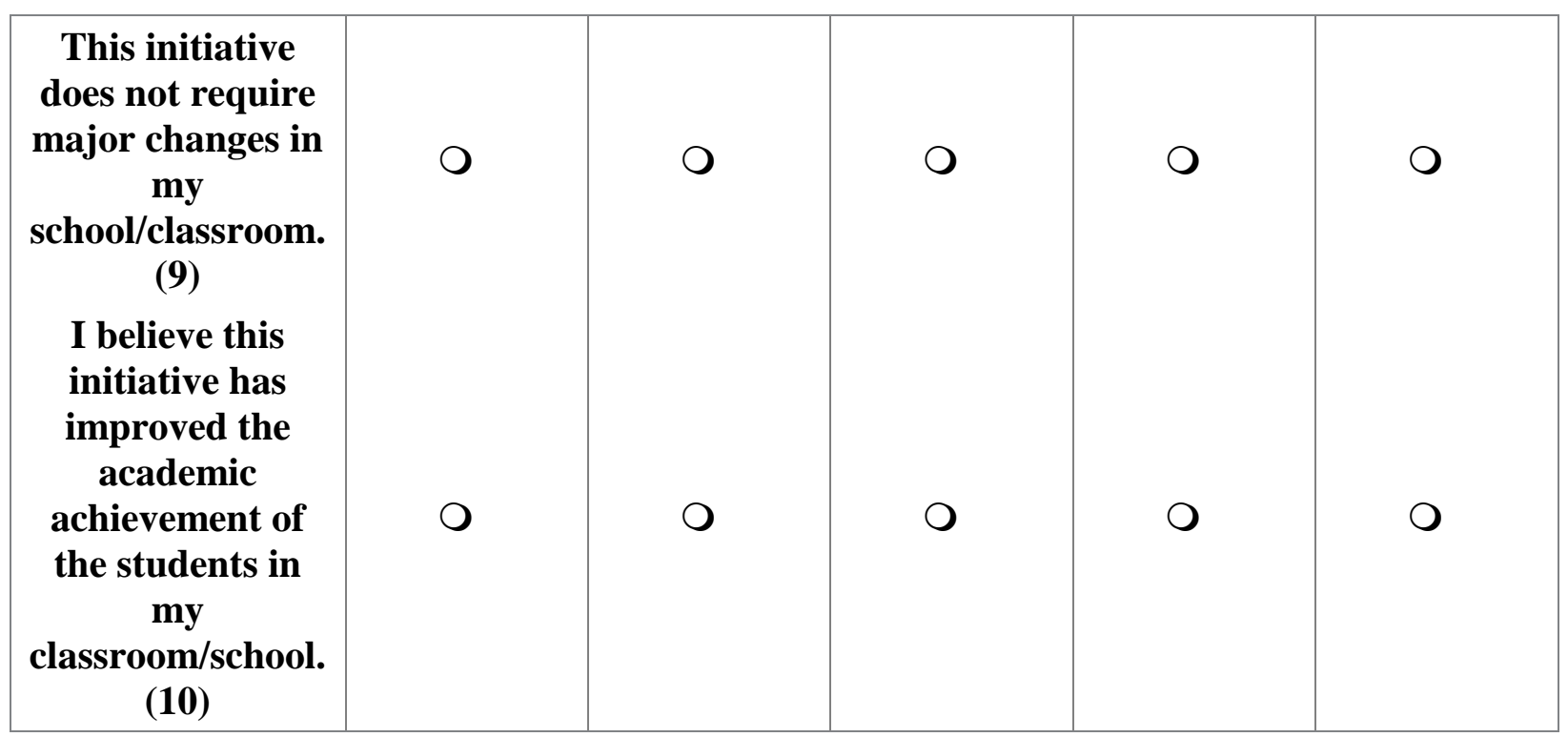

Teaching Resilience and Coping Skills

This includes teaching appropriate responses, providing students with a locus of control, increasing students' efficacy, recognizing and respecting relationships, incorporating students' different cultures and backgrounds, and teaching planning and organization and cause and effect (Tileston \& Darling, 2008).

In summarizing their 35-year study of resiliency in childhood, Werner and Smith found that resilient students "succeeded in school, managed home and social life well, and set realistic educational and vocational goals and expec-tations for themselves" $(1982$, p. 11).

In West Virginia the Responsible Students through School-Wide Behavior provides students with appropriate behavior skills.

Is this initiative used in your classroom/school?

O Yes (1)

O No (2) 
Check all that apply for this initiative. 4--strongly agree; 3--agree; 2 -disagree; 1--strongly disagree; and 0--does not apply 


\begin{tabular}{|c|c|c|c|c|c|}
\hline & $4(4)$ & $3(3)$ & $2(2)$ & $1(1)$ & $0(0)$ \\
\hline $\begin{array}{l}\text { I have had the } \\
\text { training that I } \\
\text { need to } \\
\text { implement this } \\
\text { initiative. (1) }\end{array}$ & 0 & O & 0 & 0 & 0 \\
\hline $\begin{array}{l}\text { I have had the } \\
\text { materials that I } \\
\text { need to } \\
\text { implement this } \\
\text { initiative. (2) }\end{array}$ & 0 & O & 0 & 0 & 0 \\
\hline $\begin{array}{l}\text { I have had the } \\
\text { necessary time to } \\
\text { implement this } \\
\text { initiative. (3) }\end{array}$ & 0 & O & 0 & 0 & 0 \\
\hline $\begin{array}{l}\text { Teachers have } \\
\text { had input into } \\
\text { the design of this } \\
\text { initiative. (4) }\end{array}$ & 0 & O & 0 & 0 & 0 \\
\hline $\begin{array}{l}\text { I have had input } \\
\text { into the } \\
\text { implementation } \\
\text { of this initiative. } \\
\text { (5) }\end{array}$ & 0 & O & 0 & 0 & 0 \\
\hline $\begin{array}{l}\text { I have had the } \\
\text { opportunity to } \\
\text { collaborate with } \\
\text { my colleagues } \\
\text { about this } \\
\text { initiative. (6) }\end{array}$ & 0 & 0 & 0 & 0 & 0 \\
\hline $\begin{array}{l}\text { This initiative is } \\
\text { consistent with } \\
\text { my beliefs about } \\
\text { improving the } \\
\text { academic } \\
\text { achievement of } \\
\text { my students. (7) }\end{array}$ & 0 & O & 0 & 0 & 0 \\
\hline $\begin{array}{l}\text { This initiative is } \\
\text { easy to } \\
\text { implement. (8) }\end{array}$ & 0 & 0 & 0 & 0 & 0 \\
\hline
\end{tabular}




\begin{tabular}{|c|c|c|c|c|c|}
\hline $\begin{array}{c}\text { This initiative } \\
\text { does not require } \\
\text { major changes in } \\
\text { my } \\
\text { school/classroom. } \\
\text { (9) } \\
\text { I believe this } \\
\text { initiative has } \\
\text { improved the } \\
\text { academic } \\
\text { achievement of } \\
\text { the students in } \\
\text { my } \\
\text { classroom/school. } \\
(10)\end{array}$ & O & 0 & 0 & 0 & 0 \\
\hline
\end{tabular}

\section{Comments}

Increased Time in Physical Activity

Increasing the amount of time in physical education classes, providing physical activities in the classroom, and providing recess time have been shown to have positive effects on cognitive skills and attitudes, academic behavior, and academic achievement (Hellmich, 2010).

In West Virginia Policy 2520.6 contains the content standards for a rigorous physical education program including the Fitnessgram.

Is this initiative used in your classroom/school?

Y Yes (1)

No (2) 
Check all that apply for this initiative. 4--strongly agree; 3--agree; 2 --disagree; 1 --strongly disagree; and 0--does not apply 


\begin{tabular}{|c|c|c|c|c|c|}
\hline & $4(4)$ & $3(3)$ & $2(2)$ & $1(1)$ & $0(0)$ \\
\hline $\begin{array}{l}\text { I have had the } \\
\text { training that I } \\
\text { need to } \\
\text { implement this } \\
\text { initiative. (1) }\end{array}$ & 0 & O & 0 & 0 & 0 \\
\hline $\begin{array}{l}\text { I have had the } \\
\text { materials that I } \\
\text { need to } \\
\text { implement this } \\
\text { initiative. (2) }\end{array}$ & 0 & O & 0 & 0 & 0 \\
\hline $\begin{array}{l}\text { I have had the } \\
\text { necessary time to } \\
\text { implement this } \\
\text { initiative. (3) }\end{array}$ & 0 & O & 0 & 0 & 0 \\
\hline $\begin{array}{l}\text { Teachers have } \\
\text { had input into } \\
\text { the design of this } \\
\text { initiative. (4) }\end{array}$ & 0 & O & 0 & 0 & 0 \\
\hline $\begin{array}{l}\text { I have had input } \\
\text { into the } \\
\text { implementation } \\
\text { of this initiative. } \\
\text { (5) }\end{array}$ & 0 & O & 0 & 0 & 0 \\
\hline $\begin{array}{l}\text { I have had the } \\
\text { opportunity to } \\
\text { collaborate with } \\
\text { my colleagues } \\
\text { about this } \\
\text { initiative. (6) }\end{array}$ & 0 & 0 & 0 & 0 & 0 \\
\hline $\begin{array}{l}\text { This initiative is } \\
\text { consistent with } \\
\text { my beliefs about } \\
\text { improving the } \\
\text { academic } \\
\text { achievement of } \\
\text { my students. (7) }\end{array}$ & 0 & O & 0 & 0 & 0 \\
\hline $\begin{array}{l}\text { This initiative is } \\
\text { easy to } \\
\text { implement. (8) }\end{array}$ & 0 & O & 0 & 0 & 0 \\
\hline
\end{tabular}




\begin{tabular}{|c|c|c|c|c|c|}
\hline $\begin{array}{c}\text { This initiative } \\
\text { does not require } \\
\text { major changes in } \\
\text { my } \\
\text { school/classroom. } \\
\text { (9) } \\
\text { I believe this } \\
\text { initiative has } \\
\text { improved the } \\
\text { academic } \\
\text { achievement of } \\
\text { the students in } \\
\text { my } \\
\text { classroom/school. } \\
(10)\end{array}$ & 0 & 0 & 0 & 0 & 0 \\
\hline
\end{tabular}

\section{Comments}

\section{Arts Education.}

Arts education is used for a range of desirable outcomes including math ability, memory skills, and reading.

Training in music has been shown to improve cognitive memory by making strategic changes in the brain where retrievable memories are maintained (Jonides, 2008). Education in visual arts also has been shown to improve math calculation (Wandell et al., 2008).

Is this initiative used in your classroom/school?

O Yes (1)

O No (2) 
Check all that apply for this initiative. 4--strongly agree; 3--agree; 2 --disagree; 1 --strongly disagree; and 0--does not apply 


\begin{tabular}{|c|c|c|c|c|c|}
\hline & $4(4)$ & $3(3)$ & $2(2)$ & $1(1)$ & $0(0)$ \\
\hline $\begin{array}{l}\text { I have had the } \\
\text { training that I } \\
\text { need to } \\
\text { implement this } \\
\text { initiative. (1) }\end{array}$ & 0 & O & 0 & 0 & 0 \\
\hline $\begin{array}{l}\text { I have had the } \\
\text { materials that I } \\
\text { need to } \\
\text { implement this } \\
\text { initiative. (2) }\end{array}$ & 0 & O & 0 & 0 & 0 \\
\hline $\begin{array}{l}\text { I have had the } \\
\text { necessary time to } \\
\text { implement this } \\
\text { initiative. (3) }\end{array}$ & 0 & O & 0 & 0 & 0 \\
\hline $\begin{array}{l}\text { Teachers have } \\
\text { had input into } \\
\text { the design of this } \\
\text { initiative. (4) }\end{array}$ & 0 & O & 0 & 0 & 0 \\
\hline $\begin{array}{l}\text { I have had input } \\
\text { into the } \\
\text { implementation } \\
\text { of this initiative. } \\
\text { (5) }\end{array}$ & 0 & O & 0 & 0 & 0 \\
\hline $\begin{array}{l}\text { I have had the } \\
\text { opportunity to } \\
\text { collaborate with } \\
\text { my colleagues } \\
\text { about this } \\
\text { initiative. (6) }\end{array}$ & 0 & 0 & 0 & 0 & 0 \\
\hline $\begin{array}{l}\text { This initiative is } \\
\text { consistent with } \\
\text { my beliefs about } \\
\text { improving the } \\
\text { academic } \\
\text { achievement of } \\
\text { my students. (7) }\end{array}$ & 0 & O & 0 & 0 & 0 \\
\hline $\begin{array}{l}\text { This initiative is } \\
\text { easy to } \\
\text { implement. (8) }\end{array}$ & 0 & O & 0 & 0 & 0 \\
\hline
\end{tabular}




\begin{tabular}{|c|c|c|c|c|c|}
\hline $\begin{array}{c}\text { This initiative } \\
\text { does not require } \\
\text { major changes in } \\
\text { my } \\
\text { school/classroom. } \\
\text { (9) } \\
\text { I believe this } \\
\text { initiative has } \\
\text { improved the } \\
\text { academic } \\
\text { achievement of } \\
\text { the students in } \\
\text { my } \\
\text { classroom/school. } \\
(10)\end{array}$ & 0 & 0 & 0 & 0 & 0 \\
\hline
\end{tabular}

High Stakes Summative Testing

High stakes summative standardized testing is linked to state and national standards and student and teacher evaluation. These tests are typically standardized and are marketed by testing companies. Although they can be used in a formative way, these tests are usually summative and used to compare groups, students, and teachers.

In West Virginia the West Virginia General Summative Assessment is administered each spring. 
Is this initiative used in your classroom/school?

Yes (1)

No (2)

Check all that apply for this initiative. 4--strongly agree; 3--agree; 2--disagree; 1--strongly disagree; and 0--does not apply 


\begin{tabular}{|c|c|c|c|c|c|}
\hline & $4(4)$ & $3(3)$ & $2(2)$ & $1(1)$ & $0(0)$ \\
\hline $\begin{array}{l}\text { I have had the } \\
\text { training that I } \\
\text { need to } \\
\text { implement this } \\
\text { initiative. (1) }\end{array}$ & 0 & O & 0 & 0 & 0 \\
\hline $\begin{array}{l}\text { I have had the } \\
\text { materials that I } \\
\text { need to } \\
\text { implement this } \\
\text { initiative. (2) }\end{array}$ & 0 & O & 0 & 0 & 0 \\
\hline $\begin{array}{l}\text { I have had the } \\
\text { necessary time to } \\
\text { implement this } \\
\text { initiative. (3) }\end{array}$ & 0 & O & 0 & 0 & 0 \\
\hline $\begin{array}{l}\text { Teachers have } \\
\text { had input into } \\
\text { the design of this } \\
\text { initiative. (4) }\end{array}$ & 0 & O & 0 & 0 & 0 \\
\hline $\begin{array}{l}\text { I have had input } \\
\text { into the } \\
\text { implementation } \\
\text { of this initiative. } \\
\text { (5) }\end{array}$ & 0 & O & 0 & 0 & 0 \\
\hline $\begin{array}{l}\text { I have had the } \\
\text { opportunity to } \\
\text { collaborate with } \\
\text { my colleagues } \\
\text { about this } \\
\text { initiative. (6) }\end{array}$ & 0 & 0 & 0 & 0 & 0 \\
\hline $\begin{array}{l}\text { This initiative is } \\
\text { consistent with } \\
\text { my beliefs about } \\
\text { improving the } \\
\text { academic } \\
\text { achievement of } \\
\text { my students. (7) }\end{array}$ & 0 & O & 0 & 0 & 0 \\
\hline $\begin{array}{l}\text { This initiative is } \\
\text { easy to } \\
\text { implement. (8) }\end{array}$ & 0 & O & 0 & 0 & 0 \\
\hline
\end{tabular}




\begin{tabular}{|c|c|c|c|c|c|}
\hline $\begin{array}{c}\text { This initiative } \\
\text { does not require } \\
\text { major changes in } \\
\text { my } \\
\text { school/classroom. } \\
\text { (9) } \\
\text { I believe this } \\
\text { initiative has } \\
\text { improved the } \\
\text { academic } \\
\text { achievement of } \\
\text { the students in } \\
\text { my } \\
\text { classroom/school. } \\
(10)\end{array}$ & 0 & 0 & 0 & 0 & 0 \\
\hline
\end{tabular}

\section{Comments}

Formative Assessment

Formative Performance Assessment is a type of formative testing used to diagnose problems or check progress.

A New York City model in which teachers used formative performance assessment for evaluation showed better long term effects than summative assessment for students including fewer dropouts and more students attending and finishing college (New York Performance Standards Consortium, 2014). Studies have shown higher student achievement with the use of formative assessment (Carpenter, 1991; Fuchs, 1989).

Is this initiative used in your classroom/school?

O Yes (1)

O No (2) 
Check all that apply for this initiative. 4--strongly agree; 3--agree; 2 --disagree; 1 --strongly disagree; and 0--does not apply 


\begin{tabular}{|c|c|c|c|c|c|}
\hline & $4(4)$ & $3(3)$ & $2(2)$ & $1(1)$ & $0(0)$ \\
\hline $\begin{array}{l}\text { I have had the } \\
\text { training that I } \\
\text { need to } \\
\text { implement this } \\
\text { initiative. (1) }\end{array}$ & 0 & O & 0 & 0 & 0 \\
\hline $\begin{array}{l}\text { I have had the } \\
\text { materials that I } \\
\text { need to } \\
\text { implement this } \\
\text { initiative. (2) }\end{array}$ & 0 & O & 0 & 0 & 0 \\
\hline $\begin{array}{l}\text { I have had the } \\
\text { necessary time to } \\
\text { implement this } \\
\text { initiative. (3) }\end{array}$ & 0 & O & 0 & 0 & 0 \\
\hline $\begin{array}{l}\text { Teachers have } \\
\text { had input into } \\
\text { the design of this } \\
\text { initiative. (4) }\end{array}$ & 0 & O & 0 & 0 & 0 \\
\hline $\begin{array}{l}\text { I have had input } \\
\text { into the } \\
\text { implementation } \\
\text { of this initiative. } \\
\text { (5) }\end{array}$ & 0 & O & 0 & 0 & 0 \\
\hline $\begin{array}{l}\text { I have had the } \\
\text { opportunity to } \\
\text { collaborate with } \\
\text { my colleagues } \\
\text { about this } \\
\text { initiative. (6) }\end{array}$ & 0 & 0 & 0 & 0 & 0 \\
\hline $\begin{array}{l}\text { This initiative is } \\
\text { consistent with } \\
\text { my beliefs about } \\
\text { improving the } \\
\text { academic } \\
\text { achievement of } \\
\text { my students. (7) }\end{array}$ & 0 & O & 0 & 0 & 0 \\
\hline $\begin{array}{l}\text { This initiative is } \\
\text { easy to } \\
\text { implement. (8) }\end{array}$ & 0 & O & 0 & 0 & 0 \\
\hline
\end{tabular}




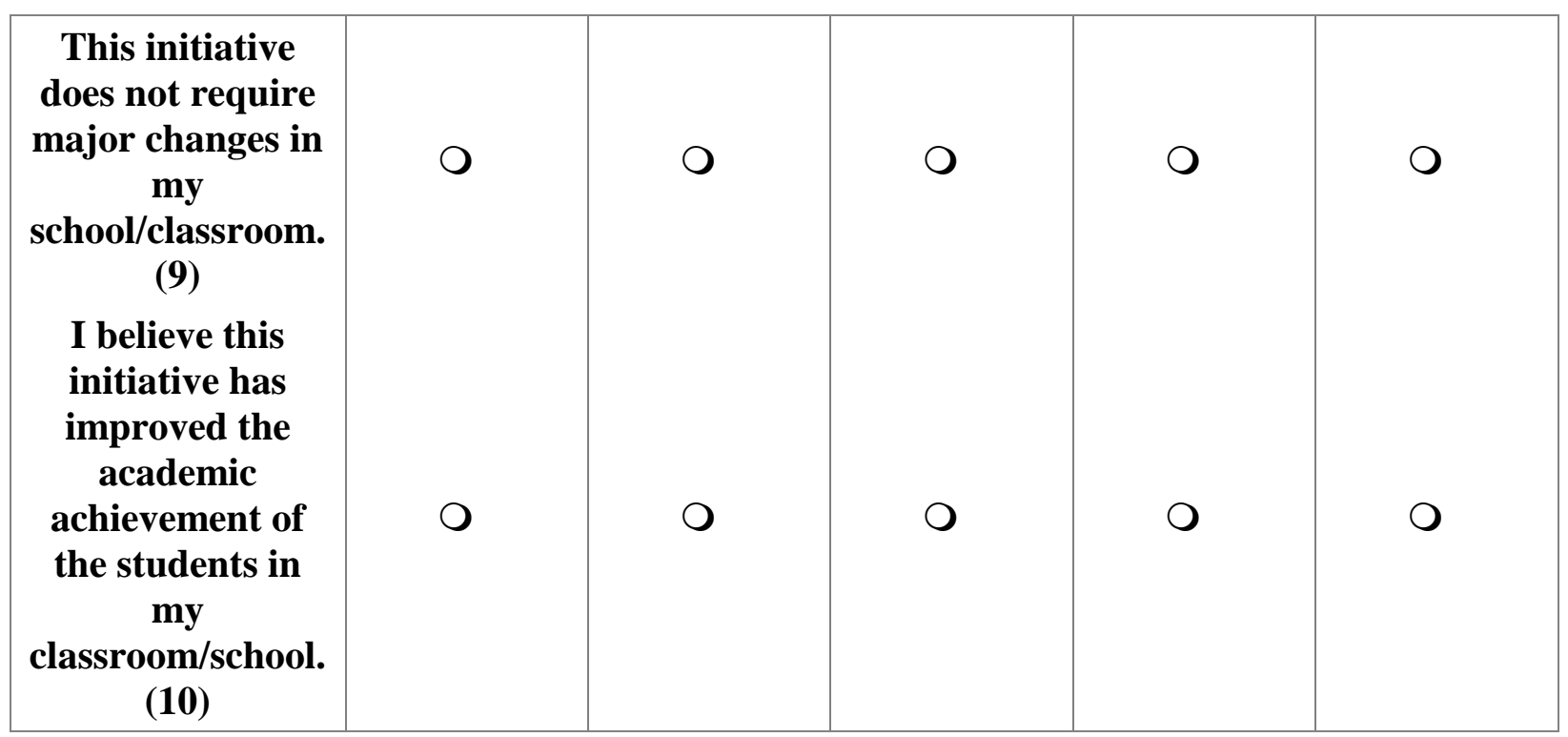

\section{Comments}

Response to Intervention (RTI)

RTI is a three-tiered approach to helping struggling readers through a series of interventions based on research proven programs.

In a study by the Society for Research on Educational Effectiveness, a leveled literacy intervention program positively impacted student achievement especially for disadvantaged youth (Ransford-Kaldon et al., 2011). In a 2010 study of 83 students who used RTI, 82\% achieved grade level benchmarks using intensive tier 2 interventions (Maskill, 2012).

In West Virginia RTI, renamed in 2010-2011 to Support for Personalized Learning (SPL), is used in Title I schools in grades K-3.

Is this initiative used in your classroom/school?

Yes (1)

No (2) 
Check all that apply for this initiative. 4--strongly agree; 3--agree; 2 --disagree; 1 --strongly disagree; and 0--does not apply 


\begin{tabular}{|c|c|c|c|c|c|}
\hline & $4(4)$ & $3(3)$ & $2(2)$ & $1(1)$ & $0(0)$ \\
\hline $\begin{array}{l}\text { I have had the } \\
\text { training that I } \\
\text { need to } \\
\text { implement this } \\
\text { initiative. (1) }\end{array}$ & 0 & O & 0 & 0 & 0 \\
\hline $\begin{array}{l}\text { I have had the } \\
\text { materials that I } \\
\text { need to } \\
\text { implement this } \\
\text { initiative. (2) }\end{array}$ & 0 & O & 0 & 0 & 0 \\
\hline $\begin{array}{l}\text { I have had the } \\
\text { necessary time to } \\
\text { implement this } \\
\text { initiative. (3) }\end{array}$ & 0 & O & 0 & 0 & 0 \\
\hline $\begin{array}{l}\text { Teachers have } \\
\text { had input into } \\
\text { the design of this } \\
\text { initiative. (4) }\end{array}$ & 0 & O & 0 & 0 & 0 \\
\hline $\begin{array}{l}\text { I have had input } \\
\text { into the } \\
\text { implementation } \\
\text { of this initiative. } \\
\text { (5) }\end{array}$ & 0 & O & 0 & 0 & 0 \\
\hline $\begin{array}{l}\text { I have had the } \\
\text { opportunity to } \\
\text { collaborate with } \\
\text { my colleagues } \\
\text { about this } \\
\text { initiative. (6) }\end{array}$ & 0 & 0 & 0 & 0 & 0 \\
\hline $\begin{array}{l}\text { This initiative is } \\
\text { consistent with } \\
\text { my beliefs about } \\
\text { improving the } \\
\text { academic } \\
\text { achievement of } \\
\text { my students. (7) }\end{array}$ & 0 & O & 0 & 0 & 0 \\
\hline $\begin{array}{l}\text { This initiative is } \\
\text { easy to } \\
\text { implement. (8) }\end{array}$ & 0 & O & 0 & 0 & 0 \\
\hline
\end{tabular}




\begin{tabular}{|c|c|c|c|c|c|}
\hline $\begin{array}{c}\text { This initiative } \\
\text { does not require } \\
\text { major changes in } \\
\text { my } \\
\text { school/classroom. } \\
\text { (9) } \\
\text { I believe this } \\
\text { initiative has } \\
\text { improved the } \\
\text { academic } \\
\text { achievement of } \\
\text { the students in } \\
\text { my } \\
\text { classroom/school. } \\
(10)\end{array}$ & 0 & 0 & 0 & 0 & 0 \\
\hline
\end{tabular}

\section{Comments}

\section{Differentiated Instruction}

In practice, it involves "...offering several different learning experiences in response to students' varied needs” (Ravitch, 2007, p. 75).

Although there is limited research on the effects of differentiated instruction, most studies show a positive correlation with achievement and attitude (Rock et al., 2008).

In West Virginia the Middle School Differentiated Instruction Project included 20 special education teachers and 27 general education teachers who then provided on-going training and professional development for teachers across the state.

Is this initiative used in your classroom/school?

O Yes (1)

O No (2) 
Check all that apply for this initiative. 4--strongly agree; 3--agree; 2 --disagree; 1 --strongly disagree; and 0--does not apply 


\begin{tabular}{|c|c|c|c|c|c|}
\hline & $4(4)$ & $3(3)$ & $2(2)$ & $1(1)$ & $0(0)$ \\
\hline $\begin{array}{l}\text { I have had the } \\
\text { training that I } \\
\text { need to } \\
\text { implement this } \\
\text { initiative. (1) }\end{array}$ & 0 & 0 & 0 & 0 & 0 \\
\hline $\begin{array}{l}\text { I have had the } \\
\text { materials that I } \\
\text { need to } \\
\text { implement this } \\
\text { initiative. }(2)\end{array}$ & 0 & 0 & 0 & 0 & 0 \\
\hline $\begin{array}{l}\text { I have had the } \\
\text { necessary time to } \\
\text { implement this } \\
\text { initiative. (3) }\end{array}$ & 0 & $\bigcirc$ & 0 & 0 & 0 \\
\hline $\begin{array}{l}\text { Teachers have } \\
\text { had input into } \\
\text { the design of this } \\
\text { initiative. (4) }\end{array}$ & 0 & 0 & 0 & 0 & 0 \\
\hline $\begin{array}{l}\text { I have had input } \\
\text { into the } \\
\text { implementation } \\
\text { of this initiative. } \\
\text { (5) }\end{array}$ & 0 & 0 & 0 & 0 & 0 \\
\hline $\begin{array}{l}\text { I have had the } \\
\text { opportunity to } \\
\text { collaborate with } \\
\text { my colleagues } \\
\text { about this } \\
\text { initiative. (6) }\end{array}$ & 0 & 0 & 0 & 0 & 0 \\
\hline $\begin{array}{l}\text { This initiative is } \\
\text { consistent with } \\
\text { my beliefs about } \\
\text { improving the } \\
\text { academic } \\
\text { achievement of } \\
\text { my students. (7) }\end{array}$ & 0 & 0 & 0 & 0 & 0 \\
\hline $\begin{array}{l}\text { This initiative is } \\
\text { easy to } \\
\text { implement. (8) }\end{array}$ & 0 & 0 & 0 & 0 & 0 \\
\hline
\end{tabular}




\begin{tabular}{|c|c|c|c|c|c|}
\hline $\begin{array}{c}\text { This initiative } \\
\text { does not require } \\
\text { major changes in } \\
\text { my } \\
\text { school/classroom. } \\
\text { (9) } \\
\text { I believe this } \\
\text { initiative has } \\
\text { improved the } \\
\text { academic } \\
\text { achievement of } \\
\text { the students in } \\
\text { my } \\
\text { classroom/school. } \\
(10)\end{array}$ & 0 & 0 & 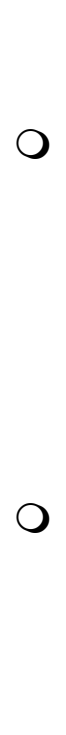 & 0 & 0 \\
\hline
\end{tabular}

\section{Early Screening}

Early screening of children can include diagnoses of language delays, developmental delays, and health problems.

The Nationwide Children's Website (2015) reports that early interventions make a significant difference when treating children in the autism disorders spectrum. Studies have shown that children who receive early intervention and treatment for developmental disorders are more likely to graduate from high school, to hold jobs as adults, and are less likely to commit criminal acts than those who do not receive early intervention (Stoppler, 2014).

In West Virginia a Health Check or comparable comprehensive physical examination is required for enrollment into Pre-K.

Is this initiative used in your school?

O Yes (1)

O No (2) 
Check all that apply for this initiative. 4--strongly agree; 3--agree; 2 --disagree; 1 --strongly disagree; and 0--does not apply 


\begin{tabular}{|c|c|c|c|c|c|}
\hline & $4(4)$ & $3(3)$ & $2(2)$ & $1(1)$ & $0(0)$ \\
\hline $\begin{array}{l}\text { I have had the } \\
\text { training that I } \\
\text { need to } \\
\text { implement this } \\
\text { initiative. (1) }\end{array}$ & 0 & O & 0 & 0 & 0 \\
\hline $\begin{array}{l}\text { I have had the } \\
\text { materials that I } \\
\text { need to } \\
\text { implement this } \\
\text { initiative. (2) }\end{array}$ & 0 & O & 0 & 0 & 0 \\
\hline $\begin{array}{l}\text { I have had the } \\
\text { necessary time to } \\
\text { implement this } \\
\text { initiative. (3) }\end{array}$ & 0 & O & 0 & 0 & 0 \\
\hline $\begin{array}{l}\text { Teachers have } \\
\text { had input into } \\
\text { the design of this } \\
\text { initiative. (4) }\end{array}$ & 0 & O & 0 & 0 & 0 \\
\hline $\begin{array}{l}\text { I have had input } \\
\text { into the } \\
\text { implementation } \\
\text { of this initiative. } \\
\text { (5) }\end{array}$ & 0 & O & 0 & 0 & 0 \\
\hline $\begin{array}{l}\text { I have had the } \\
\text { opportunity to } \\
\text { collaborate with } \\
\text { my colleagues } \\
\text { about this } \\
\text { initiative. (6) }\end{array}$ & 0 & 0 & 0 & 0 & 0 \\
\hline $\begin{array}{l}\text { This initiative is } \\
\text { consistent with } \\
\text { my beliefs about } \\
\text { improving the } \\
\text { academic } \\
\text { achievement of } \\
\text { my students. (7) }\end{array}$ & 0 & O & 0 & 0 & 0 \\
\hline $\begin{array}{l}\text { This initiative is } \\
\text { easy to } \\
\text { implement. (8) }\end{array}$ & 0 & O & 0 & 0 & 0 \\
\hline
\end{tabular}




\begin{tabular}{|c|c|c|c|c|c|}
\hline $\begin{array}{c}\text { This initiative } \\
\text { does not require } \\
\text { major changes in } \\
\text { my } \\
\text { classroom/school. } \\
\text { (9) } \\
\text { I believe this } \\
\text { initiative has } \\
\text { improved the } \\
\text { academic } \\
\text { achievement of } \\
\text { the students in } \\
\text { my } \\
\text { classroom/school. } \\
(10)\end{array}$ & 0 & . & 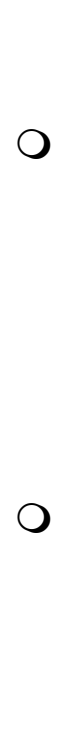 & 0 & 0 \\
\hline
\end{tabular}

\section{Comments}

School Based Health Centers and Wraparound Services

School based health centers can include dental, medical, and psychological services. Some also provide reproductive information to middle and high school students (Andrews, 2011).

Community school programs that featured more than 250 services and events were linked to positive attitudes about school for middle school students in a California study of five community schools (Castrachini \& London, 2012).

In West Virginia counties can provide health services throughout the school day to include nurses, medical providers, clinicians, dentists, dental hygienists, and counselors.

Is this initiative used in your school?

Yes (1)

No (2) 
Check all that apply for this initiative. 4--strongly agree; 3--agree; 2 --disagree; 1 --strongly disagree; and 0--does not apply 


\begin{tabular}{|c|c|c|c|c|c|}
\hline & $4(4)$ & $3(3)$ & $2(2)$ & $1(1)$ & $0(0)$ \\
\hline $\begin{array}{l}\text { I have had the } \\
\text { training that I } \\
\text { need to } \\
\text { implement this } \\
\text { initiative. (1) }\end{array}$ & 0 & 0 & 0 & 0 & 0 \\
\hline $\begin{array}{l}\text { I have had the } \\
\text { materials that I } \\
\text { need to } \\
\text { implement this } \\
\text { initiative. }(2)\end{array}$ & 0 & 0 & 0 & 0 & 0 \\
\hline $\begin{array}{l}\text { I have had the } \\
\text { necessary time to } \\
\text { implement this } \\
\text { initiative. (3) }\end{array}$ & 0 & $\bigcirc$ & 0 & 0 & 0 \\
\hline $\begin{array}{l}\text { Teachers have } \\
\text { had input into } \\
\text { the design of this } \\
\text { initiative. (4) }\end{array}$ & 0 & 0 & 0 & 0 & 0 \\
\hline $\begin{array}{l}\text { I have had input } \\
\text { into the } \\
\text { implementation } \\
\text { of this initiative. } \\
\text { (5) }\end{array}$ & 0 & 0 & 0 & 0 & 0 \\
\hline $\begin{array}{l}\text { I have had the } \\
\text { opportunity to } \\
\text { collaborate with } \\
\text { my colleagues } \\
\text { about this } \\
\text { initiative. (6) }\end{array}$ & 0 & 0 & 0 & 0 & 0 \\
\hline $\begin{array}{l}\text { This initiative is } \\
\text { consistent with } \\
\text { my beliefs about } \\
\text { improving the } \\
\text { academic } \\
\text { achievement of } \\
\text { my students. (7) }\end{array}$ & 0 & 0 & 0 & 0 & 0 \\
\hline $\begin{array}{l}\text { This initiative is } \\
\text { easy to } \\
\text { implement. (8) }\end{array}$ & 0 & 0 & 0 & 0 & 0 \\
\hline
\end{tabular}




\begin{tabular}{|c|c|c|c|c|c|}
\hline $\begin{array}{c}\text { This initiative } \\
\text { does not require } \\
\text { major changes in } \\
\text { my } \\
\text { school/classroom. } \\
\text { (9) } \\
\text { I believe this } \\
\text { initiative has } \\
\text { improved the } \\
\text { academic } \\
\text { achievement of } \\
\text { the students in } \\
\text { my } \\
\text { classroom/school. } \\
(10)\end{array}$ & 0 & 0 & 0 & 0 & 0 \\
\hline
\end{tabular}

\section{Comments}

Food and Nutrition Programs.

Food and nutrition programs for families include free breakfast and lunch programs, the Child and Adult Care Food Program and nutrition programs for women who are pregnant.

Studies show that nutrition programs lead to improved behavior, attendance, and test scores (Ford, 2013). In a study of 5200 fifth-graders, those who ate more fruits and vegetables and who had high diet quality scores including fewer calories and less saturated fat were $41 \%$ "...less likely to fail a standardized reading and writing test" ("Good Food," 2008).

In West Virginia the Department of Education administers many nutrition programs: Community Eligibility Option; National School Lunch Program; Child and Adult Care Food Program; Summer Food Service Program; Fresh Fruit and Vegetable Program; School Breakfast Program; and the Special Milk Program.

Is this initiative used in your classroom/school?

Yes (1)

No (2) 
Check all that apply for this initiative. 4--strongly agree; 3--agree; 2 --disagree; 1 --strongly disagree; and 0--does not apply 


\begin{tabular}{|c|c|c|c|c|c|}
\hline & $4(4)$ & $3(3)$ & $2(2)$ & $1(1)$ & $0(0)$ \\
\hline $\begin{array}{l}\text { I have had the } \\
\text { training that I } \\
\text { need to } \\
\text { implement this } \\
\text { initiative. (1) }\end{array}$ & 0 & 0 & 0 & 0 & 0 \\
\hline $\begin{array}{l}\text { I have had the } \\
\text { materials that I } \\
\text { need to } \\
\text { implement this } \\
\text { initiative. }(2)\end{array}$ & 0 & 0 & 0 & 0 & 0 \\
\hline $\begin{array}{l}\text { I have had the } \\
\text { necessary time to } \\
\text { implement this } \\
\text { initiative. (3) }\end{array}$ & 0 & $\bigcirc$ & 0 & 0 & 0 \\
\hline $\begin{array}{l}\text { Teachers have } \\
\text { had input into } \\
\text { the design of this } \\
\text { initiative. (4) }\end{array}$ & 0 & 0 & 0 & 0 & 0 \\
\hline $\begin{array}{l}\text { I have had input } \\
\text { into the } \\
\text { implementation } \\
\text { of this initiative. } \\
\text { (5) }\end{array}$ & 0 & 0 & 0 & 0 & 0 \\
\hline $\begin{array}{l}\text { I have had the } \\
\text { opportunity to } \\
\text { collaborate with } \\
\text { my colleagues } \\
\text { about this } \\
\text { initiative. (6) }\end{array}$ & 0 & 0 & 0 & 0 & 0 \\
\hline $\begin{array}{l}\text { This initiative is } \\
\text { consistent with } \\
\text { my beliefs about } \\
\text { improving the } \\
\text { academic } \\
\text { achievement of } \\
\text { my students. (7) }\end{array}$ & 0 & 0 & 0 & 0 & 0 \\
\hline $\begin{array}{l}\text { This initiative is } \\
\text { easy to } \\
\text { implement. (8) }\end{array}$ & 0 & 0 & 0 & 0 & 0 \\
\hline
\end{tabular}




\begin{tabular}{|c|c|c|c|c|c|}
\hline $\begin{array}{c}\text { This initiative } \\
\text { does not require } \\
\text { major changes in } \\
\text { my } \\
\text { school/classroom. } \\
\text { (9) } \\
\text { I believe this } \\
\text { initiative has } \\
\text { improved the } \\
\text { academic } \\
\text { achievement of } \\
\text { the students in } \\
\text { my } \\
\text { classroom/school. } \\
(10)\end{array}$ & 0 & 0 & 0 & 0 & 0 \\
\hline
\end{tabular}

\section{Comments}

National Board Certified Teachers.

National board certification for teachers is a peer-reviewed rigorous process based on performance standards (National Board for Professional Teaching Standards, 2014).

Although there are conflicting studies of its impact on student achievement, several studies have found strong evidence that National Board Certified teachers increase student achievement (Cavalluzzo, 2004).

In West Virginia National Board certification is encouraged and financially supported through the West Virginia Legislature and the Department of Education.

Is this initiative used in your classroom/school?

Yes (1)

No (2) 
Check all that apply for this initiative. 4--strongly agree; 3--agree; 2--disagree; 1--strongly disagree; and 0--does not apply 


\begin{tabular}{|c|c|c|c|c|c|}
\hline & $4(4)$ & $3(3)$ & $2(2)$ & $1(1)$ & $0(0)$ \\
\hline $\begin{array}{l}\text { I have had the } \\
\text { training that I } \\
\text { need to } \\
\text { implement this } \\
\text { initiative. (1) }\end{array}$ & 0 & O & 0 & 0 & 0 \\
\hline $\begin{array}{l}\text { I have had the } \\
\text { materials that I } \\
\text { need to } \\
\text { implement this } \\
\text { initiative. (2) }\end{array}$ & 0 & O & 0 & 0 & 0 \\
\hline $\begin{array}{l}\text { I have had the } \\
\text { necessary time to } \\
\text { implement this } \\
\text { initiative. (3) }\end{array}$ & 0 & O & 0 & 0 & 0 \\
\hline $\begin{array}{l}\text { Teachers have } \\
\text { had input into } \\
\text { the design of this } \\
\text { initiative. (4) }\end{array}$ & 0 & O & 0 & 0 & 0 \\
\hline $\begin{array}{l}\text { I have had input } \\
\text { into the } \\
\text { implementation } \\
\text { of this initiative. } \\
\text { (5) }\end{array}$ & 0 & O & 0 & 0 & 0 \\
\hline $\begin{array}{l}\text { I have had the } \\
\text { opportunity to } \\
\text { collaborate with } \\
\text { my colleagues } \\
\text { about this } \\
\text { initiative. (6) }\end{array}$ & 0 & 0 & 0 & 0 & 0 \\
\hline $\begin{array}{l}\text { This initiative is } \\
\text { consistent with } \\
\text { my beliefs about } \\
\text { improving the } \\
\text { academic } \\
\text { achievement of } \\
\text { my students. (7) }\end{array}$ & 0 & O & 0 & 0 & 0 \\
\hline $\begin{array}{l}\text { This initiative is } \\
\text { easy to } \\
\text { implement. (8) }\end{array}$ & 0 & O & 0 & 0 & 0 \\
\hline
\end{tabular}




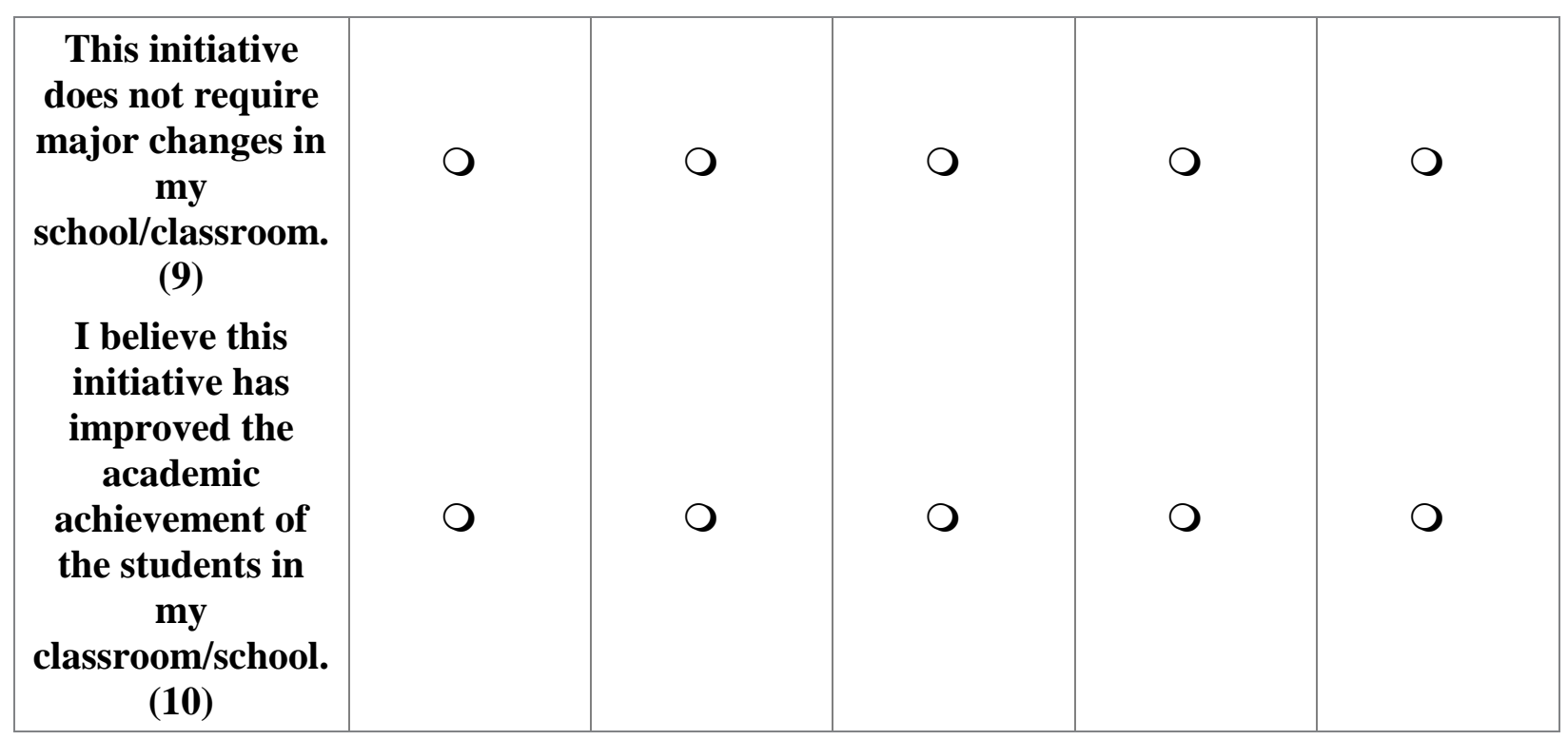

Comments

Thank you for taking this survey. If I receive an email with your name and email address saying that you took the survey, you will be entered into a drawing for a $\$ 50$ gift certificate. If you would like to see the results, please email me at rander4312@aol.com., and I will send you a copy. 